Nevada

Environmental

Restoration

Project

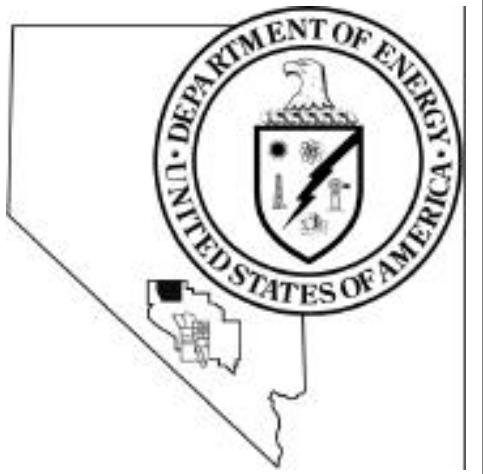

Corrective Action Investigation Plan

for Corrective Action Unit 409:

Other $W$ aste Sites

Tonopah Test Range, $\mathrm{N}$ evada

Controlled Copy N 0.: ---

Revision N 0.: 0

October 2000

Approved for public release; further dissemination unlimited.

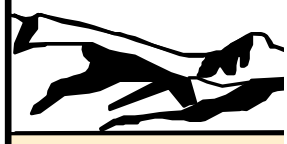

Environm ental Restoration

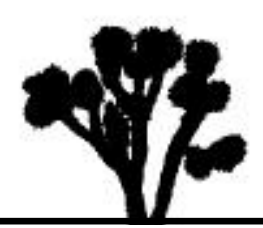

Division 
Available for sale to the public, in paper, from:

\author{
U.S. Department of Commerce \\ National Technical Information Service \\ 5285 Port Royal Road \\ Springfield, VA 22161 \\ Phone: 800.553 .6847 \\ Fax: 703.605.6900 \\ Email: orders@ntis.fedworld.gov \\ Online ordering: http//www.ntis.gov/ordering.htm
}

Available electronically at http://www.doe.gov/bridge.

Available for a processing fee to U.S. Department of Energy and its contractors, in paper, from:

\author{
U.S. Department of Energy \\ Office of Scientific and Technical Information \\ P.O. Box 62 \\ Oak Ridge, TN 37831-0062 \\ Phone: 865.576.8401 \\ Fax: 865.576.5728 \\ Email: reports@adonis.osti.gov
}

Reference herein to any specific commercial product, process, or service by trade name, trademark, manufacturer, or otherwise, does not necessarily constitute or imply its endorsement, recommendation, or favoring by the United States Government or any agency thereof or its contractors or subcontractors. 


\section{CORRECTIVE ACTION INVESTIGATION PLAN FOR CORRECTIVE ACTION UNIT 409: OTHER WASTE SITES TONOPAH TEST RANGE, NEVADA}

DOE Nevada Operations Office Las Vegas, Nevada

Controlled Copy No.:

Revision No.: 0

October 2000

Approved for public release; further dissemination unlimited. 


\title{
CORRECTIVE ACTION INVESTIGATION PLAN \\ FOR CORRECTIVE ACTION UNIT 409: \\ OTHER WASTE SITES \\ TONOPAH TEST RANGE, NEVADA
}

\author{
Approved by:_ Signature Approved Date: 10/5/00 \\ Janet Appenzeller-Wing, Project Manager \\ Industrial Sites Project
}

Approved by:

Signature Approved

Date: $10 / 5 / 00$

Runore C. Wycoff, Division Director

Environmental Restoration Division 


\section{Table of Contents}

List of Figures $\ldots \ldots \ldots \ldots \ldots \ldots \ldots \ldots \ldots \ldots \ldots \ldots \ldots \ldots \ldots \ldots \ldots \ldots$

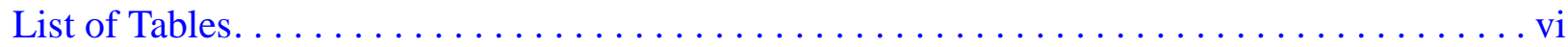

List of Acronyms and Abbreviations $\ldots \ldots \ldots \ldots \ldots \ldots \ldots \ldots \ldots \ldots \ldots \ldots \ldots \ldots \ldots \ldots$

Executive Summary . . . . . . . . . . . . . . . . . . . . . ES-1

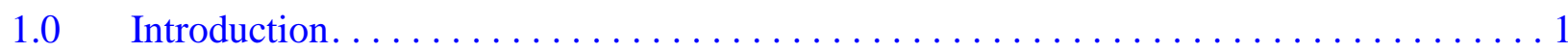

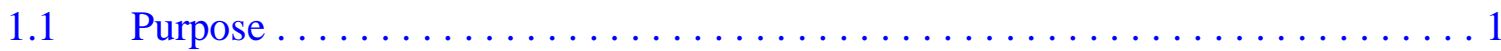

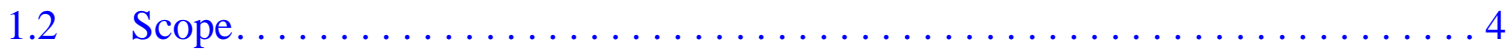

1.2.1 CAS RG-24-001-RGCR, Battery Dump Site. . . . . . . . . . . . . 4

1.2.2 CAS TA-53-001-TAB2, Septic Sludge Disposal Pit \#1 . . . . . . . . 5

1.2.3 CAS TA-53-002-TAB2, Septic Sludge Disposal Pit \#2 . . . . . . . . 5

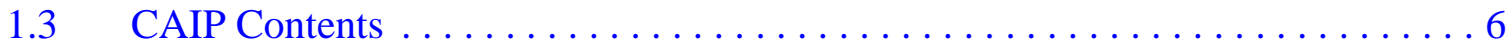

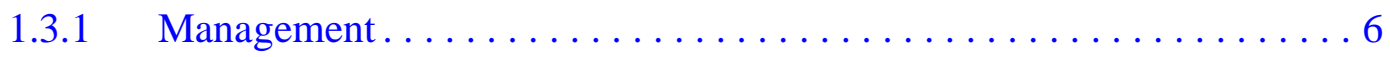

1.3.2 Technical Aspects. . . . . . . . . . . . . . . . . . . . . 6

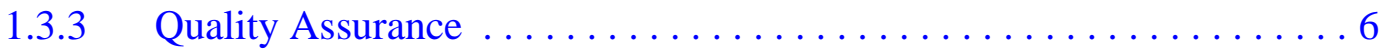

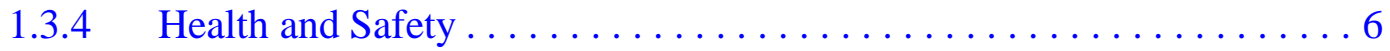

1.3.5 Public Involvement. . . . . . . . . . . . . . . . . . . 7

1.3.6 Field Sampling and Waste Management ............... 7

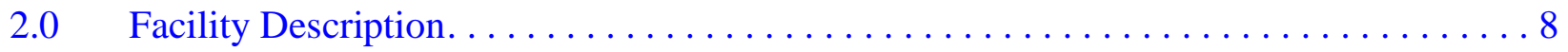

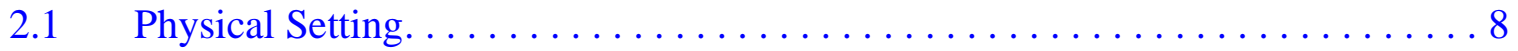

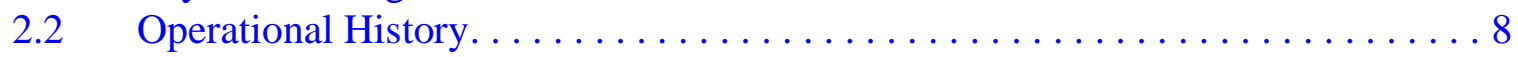

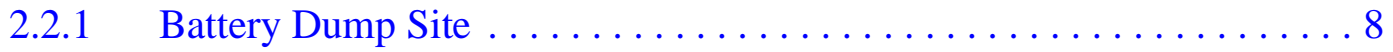

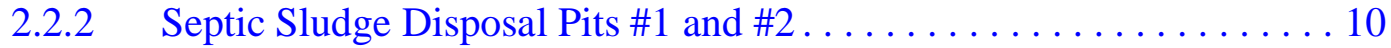

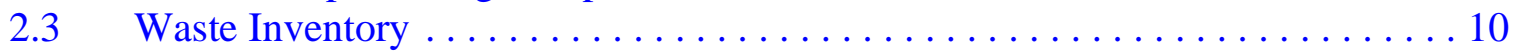

2.4 Release Information . . . . . . . . . . . . . . . . . . . . . 14

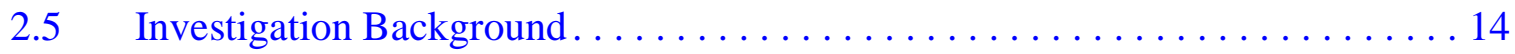

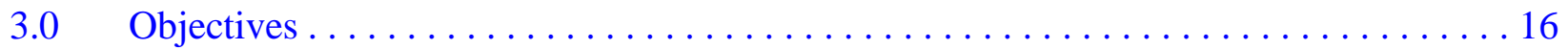

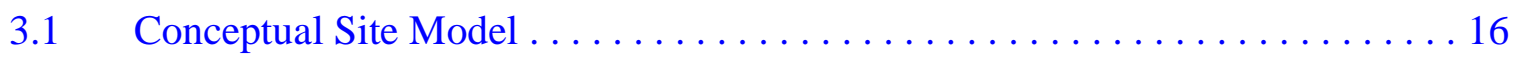

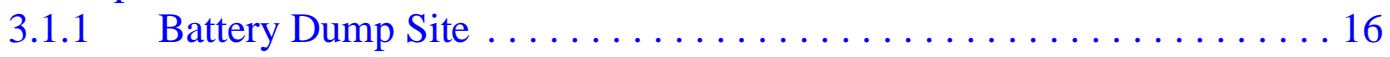

3.1.2 Septic Sludge Disposal Pits . . . . . . . . . . . . . . . . . 16

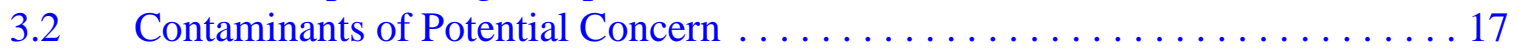

3.2.1 Battery Dump Site . . . . . . . . . . . . . . . . . 17

3.2.2 Septic Sludge Disposal Pits . . . . . . . . . . . . . . . 17

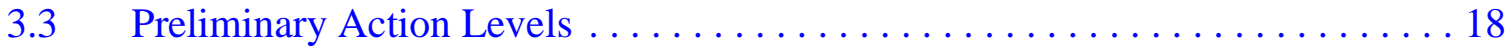

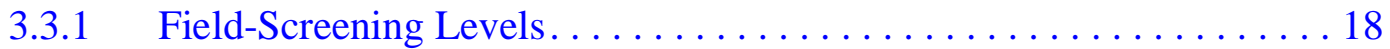

3.3.2 Chemical Preliminary Action Levels . . . . . . . . . . . . . . . . . . . . 19

3.3.3 Radiological Preliminary Action Levels . . . . . . . . . . . . . . . . . . 19 


\section{Table of Contents (Continued)}

3.4 Data Quality Objectives Process Discussion $\ldots \ldots \ldots \ldots \ldots \ldots \ldots \ldots$

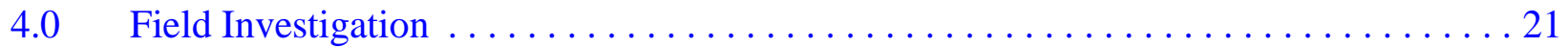

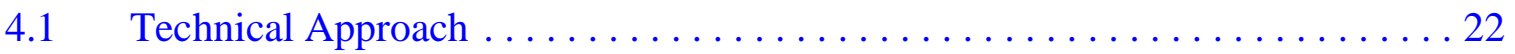

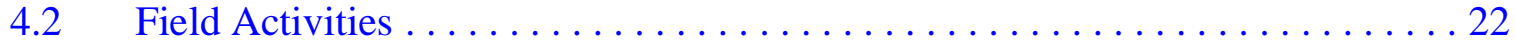

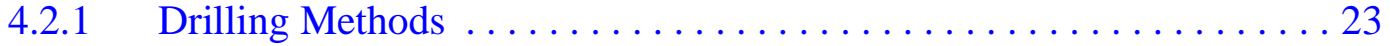

$4.2 .2 \quad$ Field Screening. . . . . . . . . . . . . . . . . . . . . 23

4.3 CAS Site-Specific Investigation Strategy . . . . . . . . . . . . . 23

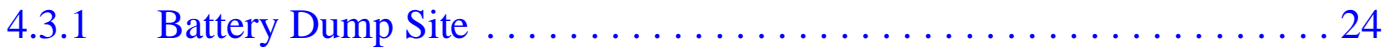

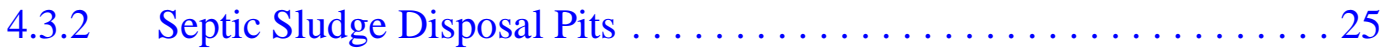

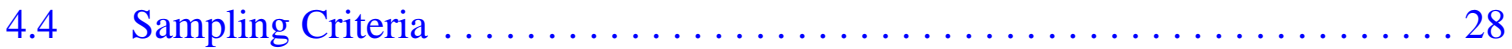

4.4.1 Environmental Samples . . . . . . . . . . . . . . . . . . . . . . . 29

4.4.2 Quality Control Samples ... . . . . . . . . . . . . . . . . . 29

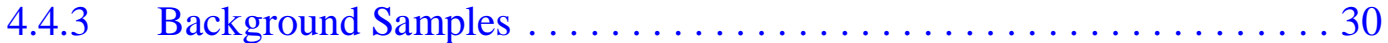

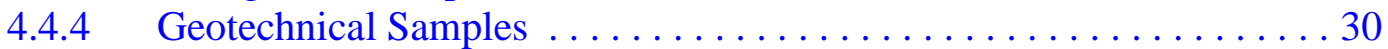

4.4.5 Bioassessment Samples . . . . . . . . . . . . . . . . . . 30

4.4.6 Waste Management Samples . . . . . . . . . . . . . . . . . 31

$5.0 \quad$ Waste Management. . . . . . . . . . . . . . . . . . . . . . . 32

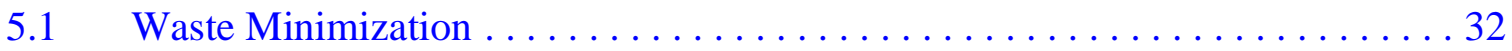

5.2 Potential Waste Streams . . . . . . . . . . . . . . . . . . 32

5.3 Investigation-Derived Waste Management $\ldots \ldots \ldots \ldots \ldots \ldots \ldots \ldots \ldots \ldots \ldots \ldots \ldots \ldots$

5.3.1 Solid Waste (Nonhazardous) . . . . . . . . . . . . . . . . . . . 34

5.3.2 Low-Level Radioactive Waste . . . . . . . . . . . . . . . . . . 34

5.3 .3 Hazardous Waste . . . . . . . . . . . . . . . . . . . 35

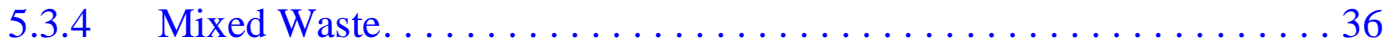

5.3.5 Hydrocarbon Waste . . . . . . . . . . . . . . . . . 36

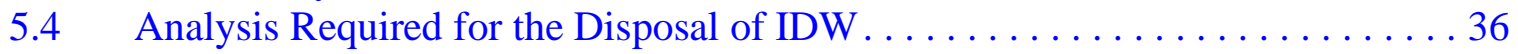

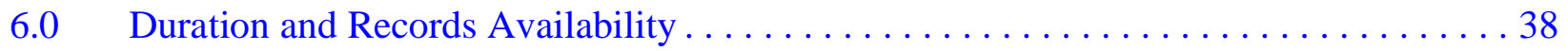

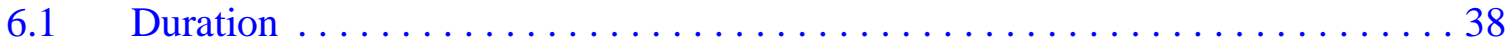

6.2 Records Availability . . . . . . . . . . . . . . . 38

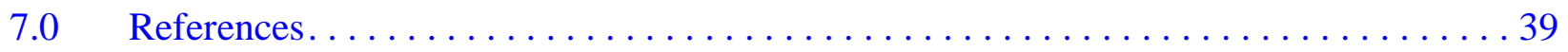

\section{Appendix A - Data Quality Objectives Worksheets}

A.1.0 Introduction. . . . . . . . . . . . . . . . . . .

A.1.1 Problem Statement . . . . . . . . . . . . . . . . . . . . . A-1

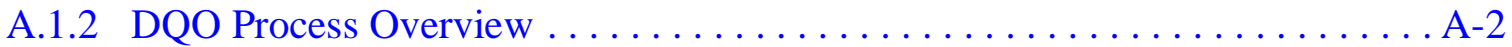




\section{Table of Contents (Continued)}

A.2.0 Conceptual Models . . . . . . . . . . . . . . . . . . . . . . . . A-7

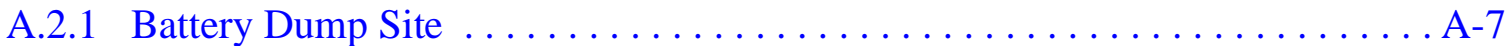

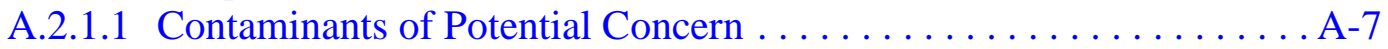

A.2.1.2 Physical Setting . . . . . . . . . . . . . . . . . . . A

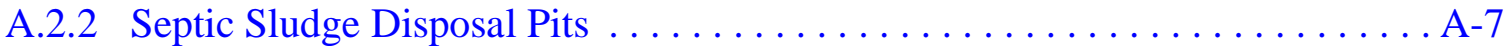

A.2.2.1 Contaminants of Potential Concern . . . . . . . . . . . . . A-10

A.2.2.2 Physical Setting . . . . . . . . . . . . . . . $\ldots \ldots \ldots$

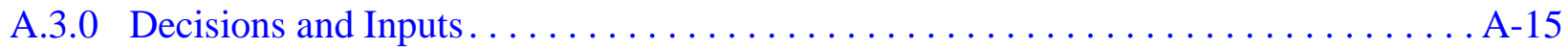

A.3.1 Decisions................................. A

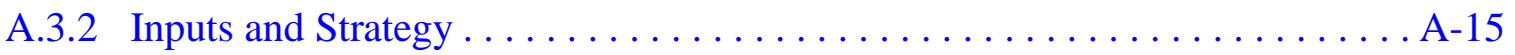

A.4.0 Field Activity/Investigation Strategy . . . . . . . . . . . . . . . . . . . A-19

A.4.1 Battery Dump Site Primary Investigation Plan. . . . . . . . . . . . . . . . A-19

A.4.2 Battery Dump Site Contingency Plan. . . . . . . . . . . . . . . . . . . A-19

A.4.3 Septic Sludge Disposal Pits Primary Investigation Plan . . . . . . . . . . . A-19

A.4.3.1 Biased Sampling Strategy. . . . . . . . . . . . . . . . . . . A-19

A.4.3.2 Sampling Locations . . . . . . . . . . . . . . . . . . . A-20

A.4.4 Septic Sludge Disposal Pits Contingency Plan. . . . . . . . . . . . . . . . . . A-23

A.4.4.1 Field-Screening Locations . . . . . . . . . . . . . . A-23

A.4.4.2 Sample Locations for Laboratory Analysis . . . . . . . . . . . . A A-23

A.4.5 Special Laboratory Requirements. . . . . . . . . . . . . . . A-23

A.5.0 Decision Rules . . . . . . . . . . . . . . . . . . . . . . . . . . . . . . . A-24

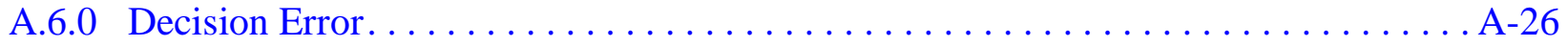

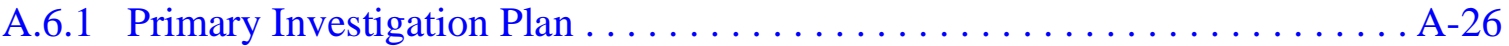

A.6.2 Contingency Plan .......................... A-26

A.7.0 References................................... A-28

\section{Appendix B - Project Organization}

B.1.0 Project Organization $\ldots \ldots \ldots \ldots \ldots \ldots \ldots \ldots \ldots \ldots \ldots \ldots \ldots \ldots \ldots \ldots \ldots \ldots \ldots$

\section{Appendix C - Analytical Table}

C.1.0 References.................................. 
Table of Contents (Continued)

Appendix D - Summary of Analytical Results

Appendix E - Response to NDEP Comments 


\section{List of Figures}

Number

Title

Page

1-1 Tonopah Test Range Location Map $\ldots \ldots \ldots \ldots \ldots \ldots \ldots \ldots \ldots \ldots \ldots \ldots \ldots \ldots$

1-2 Location of Area 3 and Cactus Springs Area Tonopah Test Range .......... 3

2-1 Battery Dump Site Photo Taken on 04/29/1998 Facing South . . . . . . . . . . . . 9

2-2 Photograph Showing Disturbed Vegetation Area Where the Septic Sludge Disposal Pits are Located - Photo Taken 03/14/1999 . . . . . . . . . . . . . . . 11

2-3 Septic Sludge Disposal Pit \#1 Photo Taken 07/24/1993 Facing East . . . . . . . . . . 12

2-4 Septic Sludge Disposal Pit \#2 Photo Taken 07/24/1993 Facing Northeast. . . . . . . 13

A.2-1 Diagrammatic Sketch of Septic Sludge Disposal Pits Area 3,

Tonopah Test Range . . . . . . . . . . . . . . . . . . . . . . A-9 


\section{List of Tables}

Number

Title

Page

4-1 Sample Collection Locations and Sampling Criteria $\ldots \ldots \ldots \ldots \ldots \ldots$

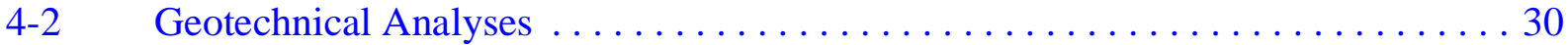

5-1 Waste Management Regulations and Requirements .............. 33

A.1-1 DQO Kickoff Meeting Participants. ..................... A-3

A.2-1 Conceptual Model for CAS RG-24-001-RGCR, Battery Dump Site . . . . . . . A A-8

A.2-2 COPCs for CAS TA-53-001-TAB2, Septic Sludge Disposal Pit \#1 and

CAS TA-53-002-TAB2, Septic Sludge Disposal Pit \#2

A.2-3 Conceptual Model for CAS TA-53-001-TAB2, Septic Sludge Disposal

Pit \#1 and CAS TA-53-002-TAB2, Septic Sludge Disposal Pit \#2 . . . . . . . . A-13

A.3-1 Decisions, Inputs, and General Strategies . . . . . . . . . . . . A-16

A.4-1 Sample Collection Locations for Laboratory Analysis . . . . . . . . . . . . . A-22

A.5-1 Activity-Specific Decision Points and Rules $\ldots \ldots \ldots \ldots \ldots \ldots \ldots$ A-25

C.1-1 Laboratory Chemical, Toxicity Characteristic Leaching Procedure, and

Radiochemistry Analytical Requirements for Industrial Sites . . . . . . . . . . C-1

D-1 Summary of Analytical Results for Detected Parameters, Tonopah Test

Range, Septic Tank Sampling 1991 Sampling Event . . . . . . . . . . . . . . . . D-1

D-2 Results of Septic Tank Sample Analysis, Tonopah Test Range,

1993 Sampling Event . . . . . . . . . . . . . . . . . . . . D-4

D-3 Summary of Sludge Sample Results for Detected Parameters

Tonopah Test Range 1999 Sampling Event . . . . . . . . . . . . . . . D-7 


\section{List of Acronyms and Abbreviations}

\begin{tabular}{|c|c|}
\hline ALARA & As-low-as-reasonably-achievable \\
\hline bgs & Below ground surface \\
\hline $\mathrm{BN}$ & Bechtel Nevada \\
\hline CADD & Corrective Action Decision Document \\
\hline CAIP & Corrective Action Investigation Plan \\
\hline CAS & Corrective Action Site(s) \\
\hline CAU & Corrective Action Unit(s) \\
\hline CFR & Code of Federal Regulations \\
\hline COPC & Contaminant(s) of potential concern \\
\hline $\mathrm{CV}$ & Coefficient of Variation \\
\hline DoD & U.S. Department of Defense \\
\hline DOE & U.S. Department of Energy \\
\hline $\mathrm{DOE} / \mathrm{NV}$ & U.S. Department of Energy, Nevada Operations Office \\
\hline DOT & U.S. Department of Transportation \\
\hline DQO & Data Quality Objective(s) \\
\hline EPA & U.S. Environmental Protection Agency \\
\hline FFACO & Federal Facility Agreement and Consent Order \\
\hline FSL & Field-screening level(s) \\
\hline FSR & Field-screening result(s) \\
\hline $\mathrm{ft}$ & Foot (feet) \\
\hline GDRO & Gasoline- and diesel-range organics \\
\hline GPR & Ground penetrating radar \\
\hline HWAA & Hazardous Waste Accumulation Area \\
\hline IDW & Investigation-derived waste \\
\hline in. & $\operatorname{Inch}(\mathrm{es})$ \\
\hline IS & Industrial Sites \\
\hline
\end{tabular}




\section{List of Acronyms and Abbreviations (Continued)}

\begin{tabular}{|c|c|}
\hline ITLV & IT Corporation, Las Vegas Office \\
\hline LLW & Low-level radioactive waste \\
\hline $\mathrm{mg} / \mathrm{kg}$ & Milligram(s) per kilogram \\
\hline $\mathrm{mi}$ & Mile(s) \\
\hline MS/MSD & Matrix spike/matrix spike duplicate(s) \\
\hline NAC & Nevada Administrative Code \\
\hline NDEP & Nevada Division of Environmental Protection \\
\hline NEPA & National Environmental Policy Act \\
\hline NTS & Nevada Test Site \\
\hline NTSWAC & Nevada Test Site Waste Acceptance Criteria \\
\hline PA & Preliminary Assessment \\
\hline PAL & Preliminary action level(s) \\
\hline PCB & Polychlorinated biphenyl(s) \\
\hline PID & Photoionization detector \\
\hline PM & Project Manager \\
\hline PPE & Personal protective equipment \\
\hline ppm & Part(s) per million \\
\hline PRG & Preliminary Remediation Goal \\
\hline QAPP & Quality Assurance Project Plan \\
\hline QA & Quality assurance \\
\hline QC & Quality control \\
\hline RCRA & Resource Conservation and Recovery Act \\
\hline SAA & Satellite Accumulation Area \\
\hline SS & Site Supervisor \\
\hline SSHASP & Site-specific health and safety plan \\
\hline SVOC & Semivolatile organic compound(s) \\
\hline
\end{tabular}




\section{List of Acronyms and Abbreviations (Continued)}

$\begin{array}{ll}\text { SWS } & \text { Septic Waste System } \\ \text { TCLP } & \text { Toxicity Characteristic Leaching Procedure } \\ \text { TEM } & \text { Technical Execution Manager } \\ \text { Th } & \text { Thorium } \\ \text { TM } & \text { Task Manager } \\ \text { TPH } & \text { Total petroleum hydrocarbon(s) } \\ \text { TTR } & \text { Tonopah Test Range } \\ \text { U } & \text { Uranium } \\ \text { UVF } & \text { Ultraviolet fluorescence } \\ \text { VOC } & \text { Volatile organic compound(s) } \\ \text { XRF } & \text { X-ray fluorescence }\end{array}$




\section{Executive Summary}

The Corrective Action Investigation Plan for Corrective Action Unit 409, Other Waste Sites (TTR) has been developed in accordance with the Federal Facility Agreement and Consent Order that was agreed to by the U.S. Department of Energy, Nevada Operations Office; the State of Nevada Division of Environmental Protection; and the U.S. Department of Defense. Corrective Action Unit 409 consists of three Corrective Action Sites:

- TA-53-001-TAB2, Septic Sludge Disposal Pit

- TA-53-002-TAB2, Septic Sludge Disposal Pit

- RG-24-001-RGCR, Battery Dump Site

This Corrective Action Investigation Plan will be used in conjunction with the Work Plan for Leachfield Corrective Action Units: Nevada Test Site and Tonopah Test Range, Nevada, Rev. 1 (DOE/NV, 1998), since the materials being investigated at the two Septic Sludge Disposal Pits are correlative to materials and potential contamination associated with leachfields. The Leachfield Work Plan was developed to streamline investigations at leachfield Corrective Action Units. This Corrective Action Investigation Plan provides investigative details specific to Corrective Action Unit 409.

The Corrective Action Sites addressed by Corrective Action Unit 409 are located at the abandoned Cactus Repeater Station, and near Bunker Two close to Area 3 of the Tonopah Test Range. The Cactus Repeater Station was a remote, battery powered, signal repeater station. The Septic Sludge Disposal Pits were used through the late 1980s as disposal sites for sludge from septic tanks located in Area 3. Effluents generated within the facilities in Area 3 were routed through sanitary waste collection systems. The sanitary waste systems were designed to dispose of sanitary or process effluents; however, analytical results from previous sampling of the septic tanks indicate the systems received hazardous effluents.

Based on site history collected to support the Data Quality Objectives process, contaminants of potential concern are the same for the two disposal pits and include volatile organic compounds, semivolatile organic compounds, total petroleum hydrocarbons as gasoline- and diesel-range organics, polychlorinated biphenyls, Resource Conservation and Recovery Act metals, and radionuclides (plutonium and depleted uranium). Additional samples will be analyzed for 
geotechnical and hydrological properties and bioassessment analyses may be performed. The volumes and concentrations of these contaminants of potential concern are unknown.

Corrective Action Site RG-24-001-RGCR (Battery Dump Site) at the Cactus Repeater Station consists of discarded lead-acid batteries and associated construction debris. This site is a Housekeeping Category site and no contaminants are expected to be encountered during the cleanup.

Detailed conceptual site models for the Corrective Action Sites are presented in Section 3.0 and Appendix A of this plan. The conceptual site models serve as the basis for the sampling strategies.

The technical approach for investigating the Corrective Action Sites within this Corrective Action Unit consists of the following activities:

- Collect the discarded batteries and associated construction debris at the Battery Dump Site for proper disposal and recycling, and document the clean-up by photographing the site. The batteries are recyclable items.

- In an undisturbed area, drill a boring near the disposal pits (Corrective Action Sites TA-53-001-TAB2 and TA-53-002-TAB2) to collect background radiological data.

- Collect soil samples from borings drilled through the center of the disposal pits suspected locations. The two geophysical anomalies will be drilled and sampled also.

- Field screen samples for volatile organic compounds, total petroleum hydrocarbons, silver, and radiological constituents.

- Analyze select samples for total volatile organic compounds, total semivolatile organic compounds, total Resource Conservation and Recovery Act metals, total petroleum hydrocarbons (gasoline- and diesel-range organics), total polychlorinated biphenyls, and radionuclides (plutonium and uranium).

- Collect samples from native soils beneath the disposal pits and analyze for geotechnical/hydrologic parameters.

- Collect and analyze bioassessment samples at the discretion of the Site Supervisor, if volatile organic compounds or total petroleum hydrocarbons contamination concentrations exceed field-screening levels.

Additional sampling and analytical details are presented in Section 4.0 of this plan. Details of the waste management strategy for the Corrective Action Unit are included in Section 5.0. 
Under the Federal Facility Agreement and Consent Order, this Corrective Action Investigation Plan will be submitted to the Nevada Division of Environmental Protection for approval. Field work will be conducted following approval of the plan. The results of the field investigation will be used to evaluate corrective action alternatives in the Corrective Action Decision Document. 


\subsection{Introduction}

This Corrective Action Investigation Plan (CAIP) has been developed in accordance with the Federal Facility Agreement and Consent Order (FFACO) that was agreed to by the U.S. Department of Energy, Nevada Operations Office (DOE/NV); the State of Nevada Division of Environmental Protection (NDEP); and the U.S. Department of Defense (DoD) (FFACO, 1996).

It is intended that this CAIP will be used in conjunction with the Work Plan for Leachfield Corrective Action Units: Nevada Test Site and Tonopah Test Range, Nevada, Rev. 1 (DOE/NV, 1998), hereafter referred to as the Leachfield Work Plan. This CAIP contains Corrective Action Unit (CAU)-specific information including facility descriptions, environmental sample collection objectives, and the criteria for conducting site investigation activities at the three Corrective Action Sites (CASs) that comprise CAU 409, Other Waste Sites (TTR). The Tonopah Test Range (TTR), included in the Nellis Air Force Range, is approximately 140 miles (mi) northwest of Las Vegas, Nevada (Figure 1-1).

Corrective Action Unit 409 is comprised of a Battery Dump Site (CAS RG-24-001-RGCR) located near Cactus Peak Road at the Cactus Repeater location, as well as a Septic Sludge Disposal Pit (CAS TA-53-001-TAB2, hereafter referred to as Septic Sludge Pit \#1); and a second Septic Sludge Disposal Pit (CAS TA-53-002-TAB2, hereafter referred to as Septic Sludge Pit \#2), located near Bunker Two close to Area 3 of the TTR (Figure 1-2).

The two Septic Sludge Disposal Pits were used for the disposal of sludge from the septic tanks located in Area 3. The Septic Sludge Disposal Pits received material until the late 1980s. There is no documentation of the dates of operation for the Septic Sludge Disposal Pits.

\subsection{Purpose}

This CAIP describes the investigation of the nature and extent of contaminants of potential concern (COPCs) at CAU 409. The general purpose of this CAIP is to:

- Determine if COPCs are present at each CAS.

- Determine if COPC concentrations exceed field-screening levels (FSLs). 


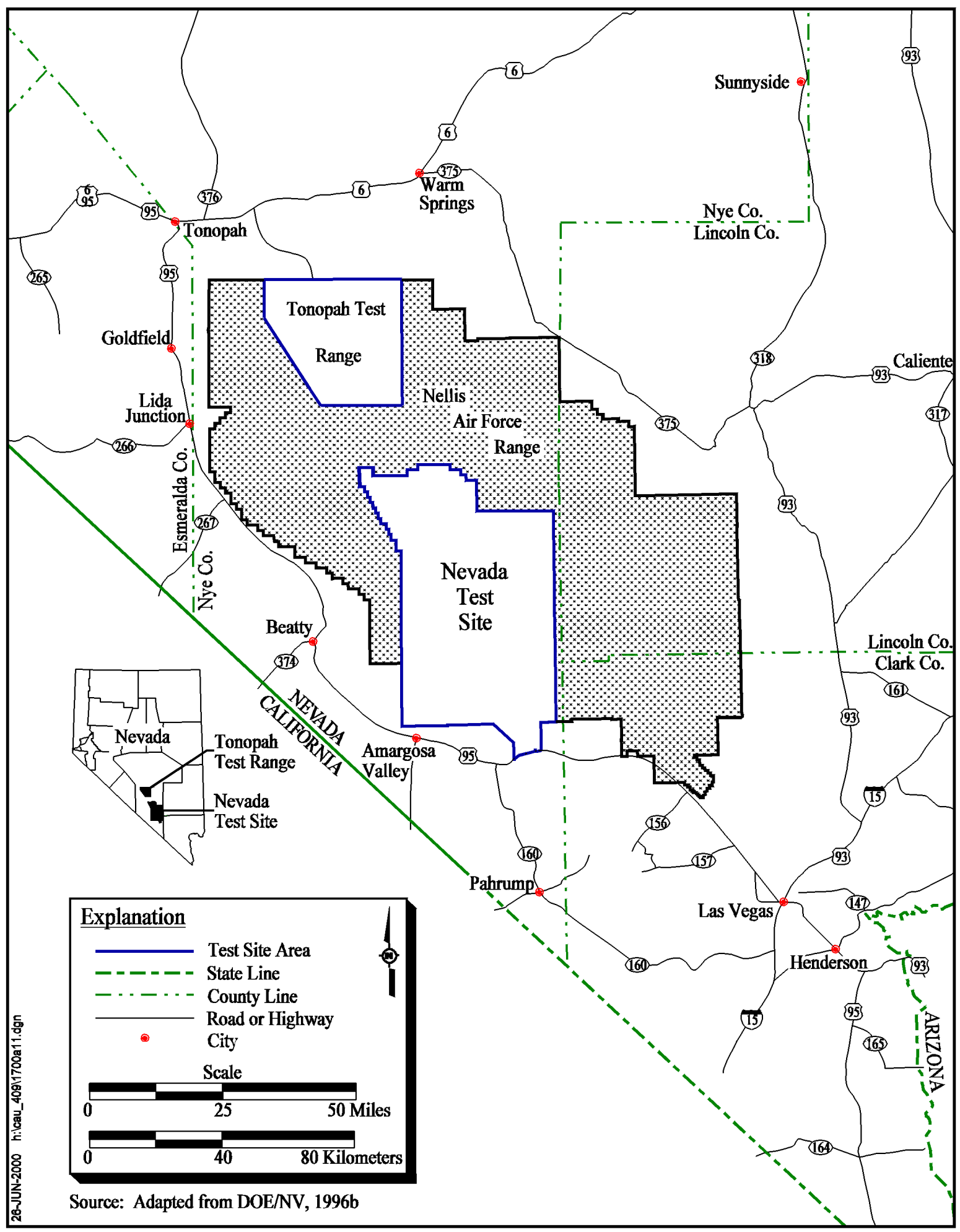

Figure 1-1

Tonopah Test Range Location Map 


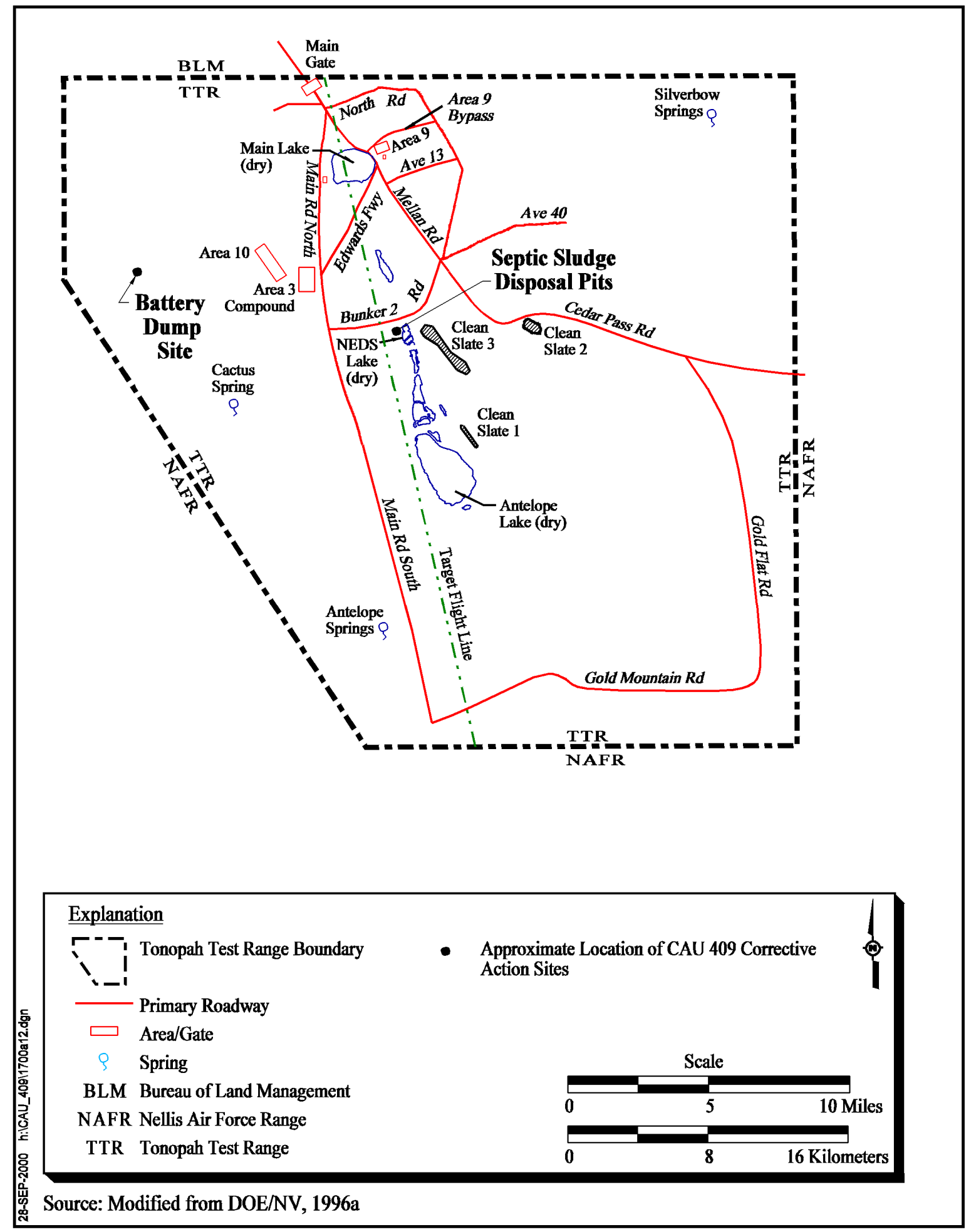

Figure 1-2

Location of Area 3 and Cactus Springs Area Tonopah Test Range 
- Determine if COPC concentrations exceed preliminary action levels (PALs).

- Determine the nature and extent of contamination with enough certainty to support selection of corrective action alternatives for each CAS.

This CAIP was developed using the U.S. Environmental Protection Agency's (EPA) Data Quality Objectives (DQOs) (EPA, 1994) process to define the goals for collecting environmental data, determine data end uses, and design a data collection program that will satisfy these goals and uses. A DQO scoping meeting was held prior to preparation of this plan. A brief summary of the DQOs is presented in Section 3.4 and a more detailed summary of the DQO process and results are included in Appendix A.

\subsection{Scope}

The scope of this CAIP is to resolve the problem statement identified in the DQO process, which states that potentially hazardous wastes were discharged to the two Septic Sludge Disposal Pits (see Appendix A). Additionally, existing information about the nature and extent of contamination at the CASs is insufficient to evaluate and select preferred corrective actions for the sites. The scope of the corrective action investigation for each CAS includes the activities described in the following sections to answer the problem statement.

The Battery Dump Site is included in the FFACO as a "Housekeeping Waste" functional category. Therefore, this CAS will be addressed under the Sectored Clean-up Work Plan for Housekeeping Category Waste Sites (DOE/NV, 2000b).

\subsubsection{CAS RG-24-001-RGCR, Battery Dump Site}

Investigation activities at this CAS include:

- Photograph discarded batteries and associated construction material/debris.

- Collect batteries and associated construction material.

- Photograph locations of items collected to confirm cleanup. 


\subsubsection{CAS TA-53-001-TAB2, Septic Sludge Disposal Pit \#1}

Investigation activities at this CAS include:

- Collect subsurface radiological background samples from a borehole drilled at an undisturbed location to $60 \mathrm{feet}(\mathrm{ft})$ below ground surface (bgs). Field-screen samples for alpha/beta-emitting radionuclides. Data will be used to establish radiological FSLs. Three samples will be submitted for laboratory analysis of isotopic uranium, isotopic plutonium, and gamma spectrometry.

- Conduct exploratory drilling through the center of the disposal pit to collect soil samples for field screening and laboratory analyses and determine the vertical extent of contamination.

- Conduct additional step-out drilling to delineate the lateral extent of contamination, if necessary. Collect additional samples if field-screening results (FSRs) indicate contamination extends laterally beyond the wall of the disposal pit.

- Conduct field screening for volatile organic compounds (VOCs), total petroleum hydrocarbons (TPH), silver, and alpha/beta-emitting radionuclides during drilling activities.

- Collect samples, at Site Supervisor's discretion, for geotechnical/hydrological and bioassessment analyses.

\subsubsection{CAS TA-53-002-TAB2, Septic Sludge Disposal Pit \#2}

Investigation activities at this CAS include:

- Conduct exploratory drilling through the center of the disposal pit to collect soil samples for field screening and laboratory analyses and determine the vertical extent of contamination.

- Conduct additional step-out drilling to delineate the lateral extent of contamination, if necessary. Collect additional samples if FSRs indicate contamination extends laterally beyond the wall of the disposal pit.

- Conduct field screening for VOCs, TPH, silver, and alpha/beta-emitting radionuclides during drilling activities.

- Collect samples, at Site Supervisor's discretion, for geotechnical/hydrological and bioassessment analyses. 


\subsection{CAIP Contents}

Section 1.0 of this CAIP provides an introduction to the project, including the purpose and scope for this corrective action investigation. Section 2.0 provides a facility description and historical summary. The remainder of the document details the investigation strategy. The FFACO (1996) requires that CAIPs address the elements discussed in the following sections.

\subsubsection{Management}

The managerial aspects of this project are discussed in the DOE/NV Project Management Plan (DOE/NV, 1994a) and a site-specific Field Management Plan that will be developed prior to field activities.

\subsubsection{Technical Aspects}

Technical aspects of this CAIP are contained in Section 3.0 and Section 4.0, and in the DQO summary presented in Appendix A.

\subsubsection{Quality Assurance}

General field and laboratory quality assurance (QA) and quality control (QC) issues, including collection of QC samples, are presented in the Industrial Sites Quality Assurance Project Plan (QAPP) (DOE/NV, 1996c). In addition, the methods for field QA/QC are further discussed in approved procedures.

\subsubsection{Health and Safety}

Field activities will be performed according to the current version of the IT Corporation, Las Vegas Office (ITLV), Health and Safety Plan (IT, 2000) and will also be supplemented with a site-specific health and safety plan written prior to the start of field work. As required by the U.S. Department of Energy (DOE) Integrated Safety Management System, these documents outline the requirements for protecting the health and safety of workers and the public, and procedures for protection of the environment. 


\subsubsection{Public Involvement}

No CAU-specific public involvement activities are planned at this time; however, an overview of public involvement is documented in the Public Involvement Plan in Appendix V of the FFACO (1996).

\subsubsection{Field Sampling and Waste Management}

Field sampling activities are discussed in Section 4.0 of this CAIP, and waste management issues are discussed in Section 5.0. The project schedule and records availability information are discussed in Section 6.0, and Section 7.0 provides a list of project references. 


\subsection{Facility Description}

Appendix A provides general background information and knowledge as examined during the DQO process as it relates to the history of the TTR and CAU 409. This information includes historical aerial photographs, ground-level photographs and site maps, and interviews with TTR personnel.

\subsection{Physical Setting}

The topography in and around TTR is characterized by north-northwest trending mountain ranges and closed alluvial basins. The TTR itself is situated in a broad, closed structural basin named Cactus Flat. Cactus Flat is a relatively flat, internally drained basin, covered almost entirely by alluvial material estimated to be greater than $800 \mathrm{ft}$ thick. The general location of the Septic Sludge Disposal Pits lie within Cactus Flat near Area 3. Topography at TTR indicates that surface water eventually flows into Cactus Flat, which includes Main and Antelope Lakes. Cactus Flat has a mean elevation of approximately 5,300 ft above mean sea level.

Depth to groundwater at the Septic Sludge Disposal Pits is estimated to be in excess of $395 \mathrm{ft}$, with groundwater flow direction generally to the north-northwest (DOE/NV, 1996b). Depth to groundwater at the Battery Dump Site is estimated at approximately $170 \mathrm{ft}$.

\subsection{Operational History}

\subsubsection{Battery Dump Site}

The Battery Dump Site is located between Cactus Peak and Cactus Springs approximately 0.1 mile west of Cactus Peak Road. Historically, the Cactus Repeater Station consisted of a mast (approximately $12 \mathrm{ft}$ tall) anchored on or next to a corrugated metal pipe (approximately $2 \mathrm{ft}$ in diameter and $2 \mathrm{ft}$ tall), and guyed by three wires/stakes. The power source for the repeater is two celled lead acid batteries. The corrugated metal pipe was covered with a wood lid and used to store new batteries. During a 1998 visit, the site was found to consist of 17 discarded batteries scattered in and around the corrugated metal pipe, along with the associated construction debris and the mast (Figure 2-1). 


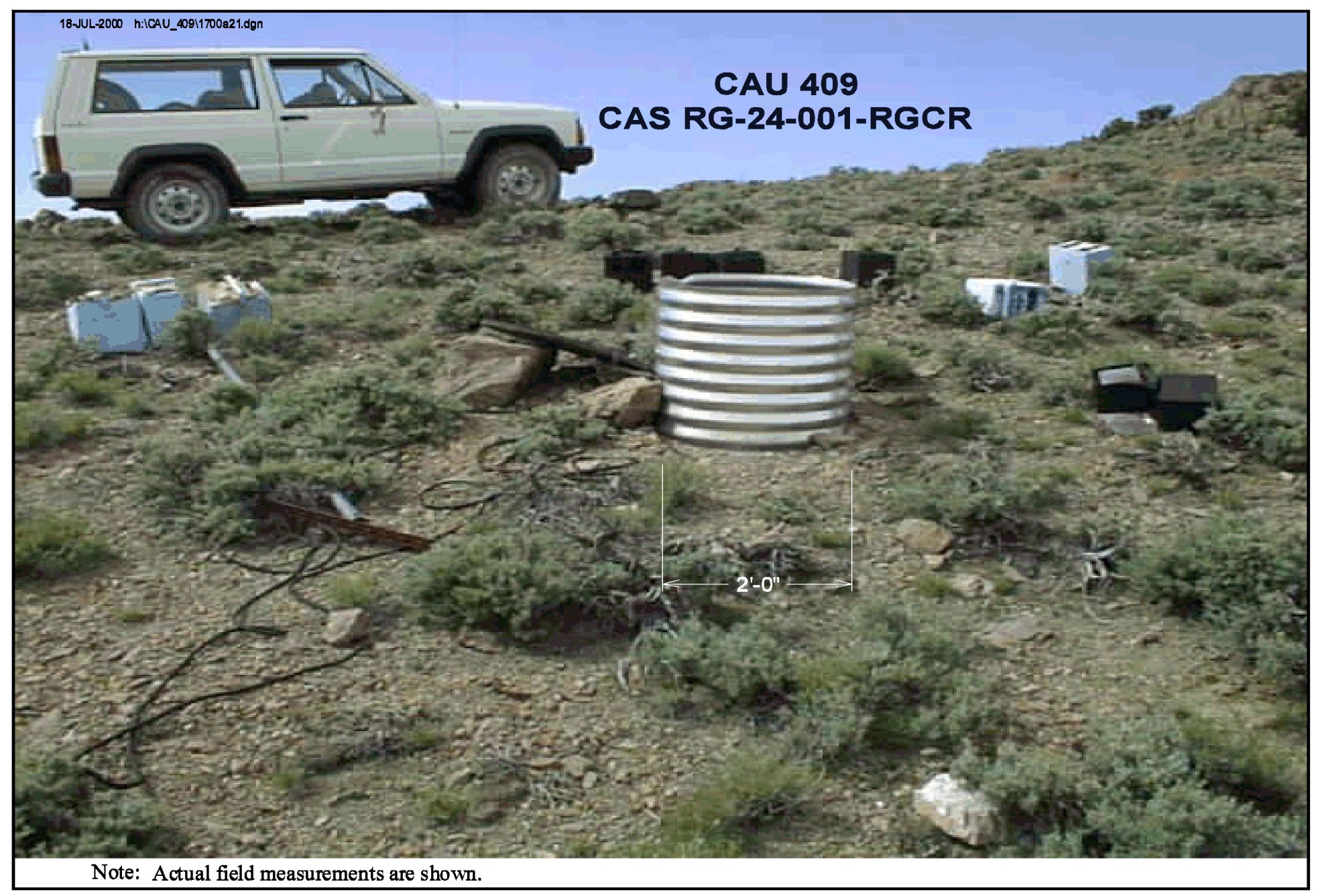

Figure 2-1

Battery Dump Site Photo Taken on 04/29/1998 Facing South 
Site investigations conducted in 1998 indicated no evidence of staining near the discarded batteries or other equipment, materials, and debris located at the Battery Dump Site.

\subsubsection{Septic Sludge Disposal Pits \#1 and \#2}

The Septic Sludge Disposal Pits are located south of Bunker 2 Road approximately $500 \mathrm{ft}$ east of Bunker Two and approximately $800 \mathrm{ft}$ west of the dry lakebeds. The site is located within an area of disturbed ground measuring approximately $120 \mathrm{ft}$ east-west by $110 \mathrm{ft}$ north-south (Figure 2-2). The pits are round depressions about $3 \mathrm{ft}$ in diameter and 3 to 6 inches (in.) deep (Figure 2-3 and Figure 2-4). Septic Sludge Disposal Pit \#1 is located at the southeast corner of the disturbed area (Figure 2-2). There is no apparent surface soil staining at either pit. The pit sites were initially identified in the Tonopah Test Range Site Priority Ranking Model (DOE/NV, 1994c) during the Preliminary Assessment interview process. According to the interview, a septic tank pumping truck from the Nevada Test Site (NTS) periodically pumped sludge out of the septic tanks in Area 3. The sludge was disposed into augured holes along Bunker 2 Road, and then backfilled. An interview held in May 2000 (Elliston, 2000) indicated a subcontractor was hired to pump out the septic tanks in Area 3 during the 1980s. The interviewee also believed the septic tank sludge was disposed of off site.

In 1990, a consolidated sewer system was installed and activated to replace the system of discrete septic tanks and leachfields in and around Area 3. Pumping the sludge out of the septic tanks has not occurred since 1990. The effluent generated in the Area 3 facility is now discharged to a nearby flocculating lagoon owned and maintained by the U.S. Air Force (DOE/NV, 1996a).

\subsection{Waste Inventory}

Unknown volumes and concentrations of hydrocarbon and chemical contaminants may have been released to subsurface soils at the two Septic Sludge Disposal Pits via the septic tank sludge. Contaminants potentially contained in the sludge would be related to the liquids passing through the Area 3 Septic Waste Systems used at TTR prior to 1990. Liquid effluent typically associated with the various shops that supported TTR daily operations included waste oil, greases, paints, solvents, fuels, and cleaning supplies. Specific details concerning the waste inventory within the source buildings 


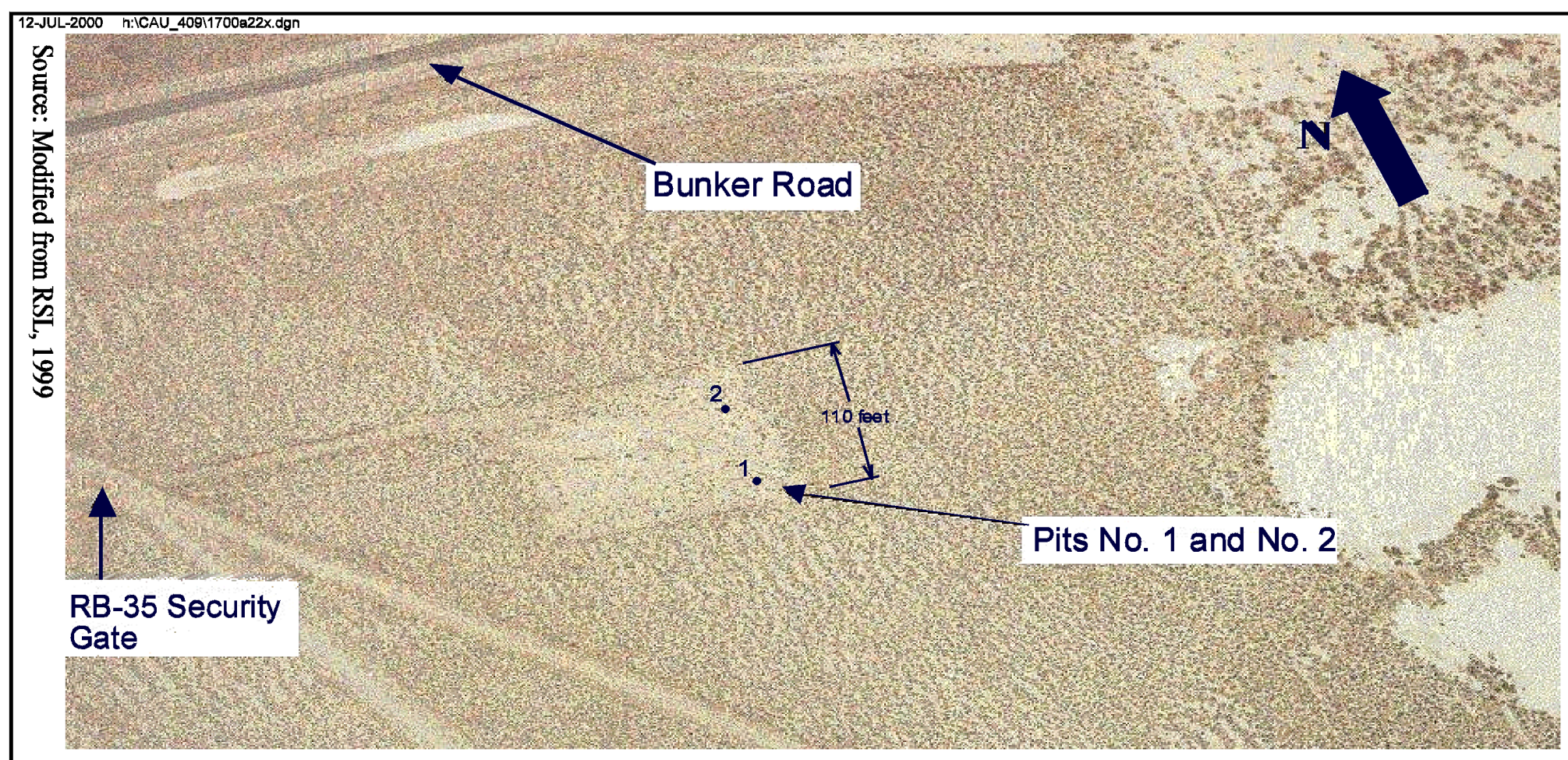

Figure 2-2

Photograph Showing Disturbed Vegetation Area Where the Septic Sludge Disposal Pits are Located - Photo Taken 03/14/1999 


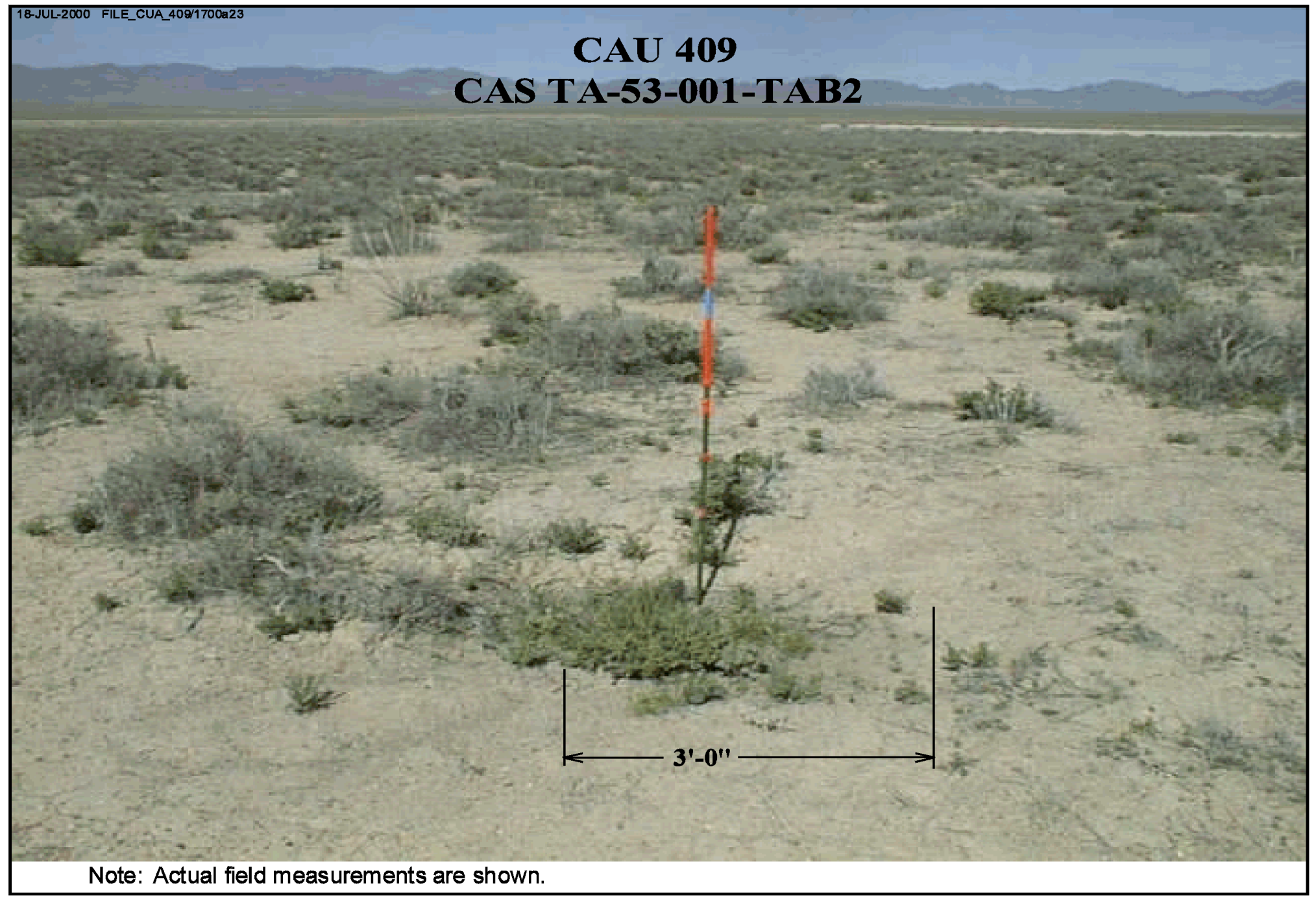

Figure 2-3

Septic Sludge Disposal Pit \#1 Photo Taken 07/24/1993 Facing East 


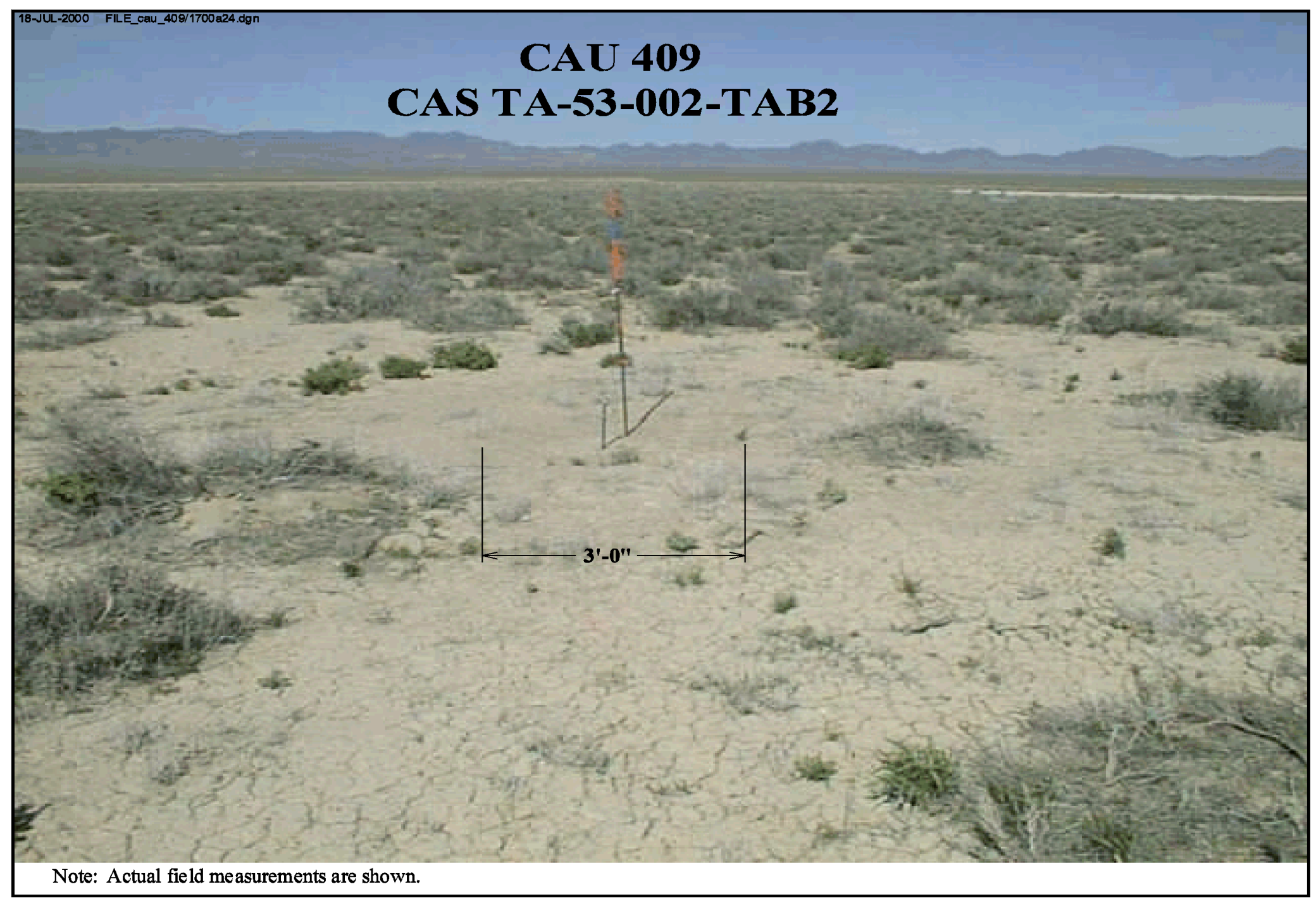

Figure 2-4

Septic Sludge Disposal Pit \#2

Photo Taken 07/24/1993 Facing Northeast 
during the various years of operation are limited (DOE/NV, 1996b). Records of liquid waste quantities discharged through the septic waste collection systems are not available.

\subsection{Release Information}

Exact quantities of contaminants released at the Septic Sludge Disposal Pits are unknown. Lateral and vertical migration of COPCs is expected to be minimal due to expected low concentrations of COPCs in possible releases, and limited driving forces.

\subsection{Investigation Background}

In accordance with the DOE/NV National Environmental Policy Act (NEPA) compliance program, a NEPA checklist will be completed prior to commencement of site investigation activities at CAU 409. This checklist compels DOE/NV to evaluate their proposed project against a list of several potential environmental impacts which include, but are not limited to, air quality, chemical use, waste generation, noise levels, and land use. Completion of the checklist results in a determination of the appropriate level of NEPA documentation by the DOE/NV NEPA Compliance Officer.

According to the Resource Conservation Recovery Act Facility Investigation Work Plan for the U.S. Department of Energy Environmental Restoration Sites, Tonopah Test Range, Nevada (DOE/NV, 1994b), a soil sampling and analysis strategy was developed for this site. However, there is no evidence to indicate this sampling effort was conducted.

Residual septage within septic tanks 33-1A, 33-1B, 33-1C, 33-2, 33-3, 33-8, and 33-10 (Area 3) at TTR was sampled by Sandia National Laboratories and analyzed in March 1991 (IT, 1991) and again in 1993 (Septic Tanks 33-1, 33-3, and 33-10 [SNL, 1994]). As part of the CAU 428 field investigation, septic sludge from septic tanks 33-1A, 33-1B, 33-3, and 33-10 was sampled and analyzed (DOE/NV, 2000a). Analytical results (Appendix D) indicated the majority of the analyzed chemical constituents were detected at trace concentrations or were not detected. Concentrations of thorium (Th)-234, uranium (U)-234, U-235, U-238; VOCs; semivolatile organic compounds (SVOCs); oils, and grease were detected at levels above background or Preliminary Remediation Goals (PRGs). 
Because the samples analyzed during this investigation were collected directly from the septic tanks, they may be representative of concentrations of constituents present in the septic tanks in years previous to 1991 (IT, 1991).

In July 1993, geophysical surveys were conducted at sites believed to be Septic Sludge Disposal Pits \#1 and \#2. The geophysical instruments utilized were ground penetrating radar (GPR) and a EM-31 electromagnetic unit. A radiological survey was also performed during the 1993 geophysical surveys.

A geophysical survey report of the 1993 field investigations was prepared in 1997 (IT, 1997). The GPR data was acquired along one south-north line and one west-east line over each disposal pit using a 300 megahertz antenna. The GPR data was not successful in delineating the disposal pits from the adjacent soils. The 1997 report also stated the EM-31 instrument survey resulted in no observed changes in conductivity over the pits.

The Environmental Restoration Sites Inventory field team performed a radiological survey using a beta-gamma pancake probe. According to the report, the measured response was within the statistical variability of the instrument utilized and was not considered above background. 


\subsection{Objectives}

The DQOs are qualitative and quantitative statements that specify the quality of the data required to support potential courses of action for CAU 409. The DQOs were developed to clearly define the purposes for which environmental data will be used and to design a data collection program that will satisfy these purposes. One element of the DQO process is the formulation of a site conceptual model.

\subsection{Conceptual Site Model}

The conceptual models for the CASs included in CAU 409 are shown in Table A.2-1 and Table A.2-3 of Appendix A. The scope and strategy of this investigation will be revised if the conceptual models provided in this CAIP fail. The conceptual models may fail if substantially different historical or operational information is discovered, or field observations demonstrate the nature and extent of contamination associated with the CASs are substantially different than anticipated. If necessary, a rescoping of the investigation will be conducted.

A brief version of the conceptual model for each CAS is provided in the following subsections.

\subsubsection{Battery Dump Site}

Located near Cactus Peak, a communications repeater station was battery powered due to the remote location. Based on preliminary investigations, it appears that new batteries were placed in a corrugated metal pipe, approximately $2 \mathrm{ft}$ in diameter and $2 \mathrm{ft}$ tall, and covered with a wooden lid. The wooden lid was attached to the metal pipe with a chain. Spent/dead batteries were discarded in the area around the corrugated metal pipe. In addition to the batteries, associated construction material/debris is scattered around the metal pipe.

\subsubsection{Septic Sludge Disposal Pits}

Based on process knowledge and early 1990s interviews of TTR workers, sludge was pumped out of the Area 3 septic tanks every few years and buried in augured holes that measured approximately $3 \mathrm{ft}$ in diameter and $49 \mathrm{ft}$ deep. 
The two pits have a combined volume of approximately 5,280 gallons. This volume would accommodate backfill material used as a cap between pumping events and approximately 10 or more pumping and disposal events.

These pumping and disposal activities are believed to have occurred until the late 1980s. Septic tank contents consisted of sanitary wastewater and small amounts of industrial wastewater containing Stoddard solvent, cutting oils, cleaning solutions, photo chemicals, medical/laboratory waste (based on a medical trailer identified as a source building for one of the Area 3 septic waste systems), and paint solvents. Unknown volumes and concentrations of these materials and other chemicals may have been released in surface and subsurface soils at the two Septic Sludge Disposal Pits. No radiological waste was documented as being disposed of in the Area 3 septic waste systems.

Based on the limited history discussed in the preceding paragraphs, it is believed the two Septic Sludge Disposal Pits contain alternating layers of septic sludge material and backfill material (composed of cuttings generated when the pits were initially augured). These layers most likely range in thickness of 1 to $4 \mathrm{ft}$ each. The upper 4 to $6 \mathrm{ft}$ of the pits is most likely cuttings or clean backfill material used as a final capping material.

\subsection{Contaminants of Potential Concern}

\subsubsection{Battery Dump Site}

As a result of the Preliminary Assessment, site history, and field data, no COPCs were identified for the Battery Dump Site.

\subsubsection{Septic Sludge Disposal Pits}

During the DQO process, COPCs for the Septic Sludge Disposal Pits were identified through process knowledge and site history. The following list provides the site-specific analytes to be measured to determine the nature and extent of potential contamination at each disposal pit:

- Total VOCs

- Total SVOCs

- Total Resource Conservation and Recovery Act (RCRA) metals

- TPH (gasoline- and diesel-range organics [GDRO]) 
- Total Polychlorinated Biphenyls (PCBs)

- Radionuclides (isotopic plutonium and isotopic uranium)

Table A.2-2 in Appendix A lists the COPCs to be analyzed for, including FSLs and PALs. Appendix $\mathrm{C}$ provides the analytical requirements which include minimum reporting limits, analytical methods, precision, and accuracy for all the analytes. Specific analyses required for disposal of investigation-derived waste (IDW) are identified in Section 5.0 of this CAIP.

Geotechnical and hydrological analysis will be performed to support closure in place of subsurface debris. Bioassessment samples may be collected if field screening detects VOC or TPH concentrations greater than FSLs. Volatile organic compounds and hydrocarbon contamination may respond to bioremediation-based corrective actions.

\subsection{Preliminary Action Levels}

The following subsections describe the FSLs and PALs for CAU 409. The FSLs for on-site, field-screening methods will be used to determine the presence of contamination and guide the investigation.

\subsubsection{Field-Screening Levels}

The following FSLs will be used for on-site, field-screening methods:

- Volatile organic compound headspace screening levels using a photoionization detector (PID) are established at 20 parts per million ( $\mathrm{ppm}$ ) or 2.5 times background, whichever is greater.

- Total petroleum hydrocarbon screening levels using appropriate field-screening methods (i.e., siteLab Ultraviolet Fluorescence [UVF] Test Kit or equivalent) are established at 75 ppm.

- $\quad$ RCRA metals - Silver screening levels using appropriate field-screening methods (i.e., $\mathrm{x}$-ray fluorescence $[\mathrm{XRF}]$ or other appropriate test instruments) are established at 1,000 ppm (based on experience at CAU 406/429, and the PRG for silver of 10,000 milligrams per kilogram $[\mathrm{mg} / \mathrm{kg}])$ in soil.

- Radiation (alpha and beta) screening levels are established as the mean background activity, plus two times the standard deviation for 20 background sample readings. The background sample readings will consist of 20 data points, collected from a "radiological background 
borehole," as described in Section 4.3.2. An FSL will be established for each instrument to be used in the field.

Concentrations exceeding FSLs will indicate potential contamination at that sample location. This information will be documented and the investigation will continue to delineate the extent of the contamination. Additionally, this data may be used to select discretionary laboratory sample locations.

\subsubsection{Chemical Preliminary Action Levels}

Off-site laboratory analytical results will be compared to the following PALs to evaluate the need for possible corrective actions:

- $\quad$ EPA Region IX PRGs for industrial soils (EPA, 1999)

- TPH concentrations above the TPH limit of 100 ppm per the NAC 445A.2272 (NAC, 1999c)

The comparison of laboratory results to preliminary action levels will be discussed in the Corrective Action Decision Document (CADD). Laboratory results above PALs indicate the presence of COPCs at levels that may require corrective action. Laboratory results below PALs indicate that corrective action is not necessary. Based on the results of this field investigation, the evaluation of potential corrective actions and the justification for a preferred action will be included in the CADD.

\subsubsection{Radiological Preliminary Action Levels}

The PALs for radionuclides in soils are isotope-specific and defined as the maximum concentration for that isotope found in environmental samples taken from undisturbed background locations. Environmental background samples previously taken near Area 3 and Area 9 at the TTR (McArthur and Miller, 1989) will be compared with the results of the background radiological field screening and sampling to be conducted for the disposal pits. In addition, the radionuclide concentrations in the CAU 409 environmental samples and background samples will be compared with the radionuclide concentrations found in environmental samples taken from undisturbed background locations in the vicinity of the NTS and TTR, presented in McArthur and Miller (1989) and Atlan-Tech (1992). 


\subsection{Data Quality Objectives Process Discussion}

Details of the DQO process are presented in Appendix A. The DQO process involves identification of the problem and a discussion of the site history and previous background data that has been collected. As concluded during the DQO meeting, based on the site history and current knowledge, the field activities at the Battery Dump Site will only involve the collection and removal of batteries and related construction debris. If during the removal activities evidence of soil staining or contamination are found, the investigation will be reevaluated.

Additionally, results of the DQO meeting indicate the need for biased sampling from the Septic Sludge Disposal Pits. Due to the potential for subsurface migration of COPCs, an investigation consisting of surface and subsurface sampling was identified. Table A.3-1 in Appendix A provides decision points and rules specific to the Septic Sludge Disposal Pits that will be used to guide the field investigation. 


\subsection{Field Investigation}

This section of the CAIP contains the sampling approach for investigating CAU 409. All sampling activities will be conducted in compliance with the Industrial Sites QAPP (DOE/NV, 1996c) and other applicable, approved procedures and instructions. Quality assurance and QC requirements for field and laboratory environmental sampling are provided in Section 4.4.2 and conform to the QA/QC requirements contained in the Industrial Sites QAPP.

Field activities will be performed in accordance with an approved site-specific health and safety plan (SSHASP) which incorporates the principles of the DOE Integrated Safety Management System. Safety, health, and protection of the environment take precedence over expediency. Site personnel will take every reasonable step to reduce the possibility of injury, illness, or accident, and to protect the environment during all project activities. The following will be taken into consideration when assessing the hazards associated with field activities:

- Potential hazards to site personnel and the public include, but are not limited to, chemicals (such as RCRA metals, VOCs, SVOCs, PCBs, and TPH), adverse and rapidly changing weather, remote location, and drilling activities.

- Proper training of all site personnel to recognize and mitigate the anticipated hazards.

- Work controls to reduce or eliminate the hazards including engineering controls, substitution of less hazardous materials, and personal protective equipment (PPE).

- Occupational exposure monitoring to prevent overexposures to hazards such as radionuclides, chemicals, and physical agents (heat, cold, high winds).

- Use of the "as-low-as-reasonably-achievable" (ALARA) principle when dealing with radiological hazards.

- Emergency and contingency planning and communications to include medical care and evacuation, decontamination and spill control measures, and appropriate notification of project management and emergency responders. 


\subsection{Technical Approach}

The following list describes general activities that may be executed during site investigations for CAU 409. Specific details of activities for the individual CASs are provided in Section 4.3.1 and Section 4.3.2, including optional scenarios dependent on field-screening results and decisions.

- Collect surface soil samples at biased locations via hand excavation.

- Photograph clean-up/material removal activities.

- Drill a borehole in an undisturbed location and collect samples to establish background radiological activity.

- Collect subsurface soil samples at biased locations via drilling methods.

- Field-screen samples for VOCs, TPH, silver, and alpha/beta-emitting radionuclides.

- Analyze selected soil samples for total VOCs, total SVOCs, total RCRA metals, TPH (GDRO), total PCBs, isotopic uranium, and isotopic plutonium. Selected samples will also be analyzed for gamma spectrometry to assist in waste management decisions.

- Collect samples from the interface of native soils and disposal features, as defined by soil staining, geology, and the presence of sludge material.

- Collect and analyze geotechnical samples.

- Collect and analyze bioassessment samples from intervals where VOCs or TPH exceed FSLs.

- Collect QC samples.

This investigation strategy will allow the nature and extent of contamination associated with each CAS to be determined. In general, each boring location will be advanced until FSRs are below FSLs for two consecutive drilling intervals to ensure the vertical extent of contamination has been established. Step-out borings may be drilled based on FSRs to determine the lateral extent of contamination.

\subsection{Field Activities}

Drilling will be the primary investigative technique to characterize CAU 409. Biased samples will be collected and field screened for VOCs, TPH, silver, and alpha/beta-emitting radionuclides (except 
those that may be collected at the Battery Dump Site, as described in Section 4.3.1). Based on FSRs, select samples will be submitted for laboratory analysis of COPCs identified in Table A.2-2.

\subsubsection{Drilling Methods}

Drilling will consist of hollow-stem auger, rotosonic, or other appropriate drilling methods. If elevated FSRs are identified during advancement of the borings in the Septic Sludge Disposal Pits, step-out borings will be advanced to evaluate the extent of lateral and vertical contaminant migration. The location of the initial step-out borings will be dictated by individual site conditions. Based on FSRs, additional step-outs may be needed to delineate plume geometry. At a minimum, step-out borings will be advanced to the lowest vertical extent of contamination (as detected by field screening) in the initial locations. Excess drill cuttings not collected as samples will be returned to the boring in the same approximate location from which they originated. Upon completion of sampling activities, all open boreholes will be filled to the ground surface with a bentonite grout mixture. If settling occurs, boreholes will be revisited and additional grout or soil will be added to bring the boreholes to grade.

\subsubsection{Field Screening}

Samples will be field screened for VOCs, TPH, silver, and alpha/beta-emitting radionuclides (except those that may be collected at the Battery Dump Site, as described in Section 4.3.1). The FSRs will guide the investigation and sampling selection and assist with health and safety and waste management decisions. The headspace method with a PID will be used to field screen for VOCs. A siteLab UVF Test Kit or equivalent will be used to field screen for TPH, and an XRF instrument (i.e., Spectrace Model 9240 X-Ray Fluorescence or equivalent) will be used for silver. An alpha/beta scintillator (i.e., Electra or equivalent) will be used to field screen for alpha/beta-emitting radionuclides. The FSLs for these field-screening methods are detailed in Section 3.3.1.

\subsection{CAS Site-Specific Investigation Strategy}

The following sections provide investigative details specific to the Battery Dump Site and the Septic Sludge Disposal Pits. Additional details are found in Section A.4.0. 


\subsubsection{Battery Dump Site}

This section includes discussions of a Primary Investigation Plan and a Contingency Plan that may be implemented if site conditions warrant.

\section{Primary Investigation Plan}

The following activities, constituting the Primary Investigation Plan, will be conducted to characterize the Battery Dump Site:

- Take a landmarked photograph of the Battery Dump Site that encompasses all the items to be collected.

- Photograph each discarded battery and each piece of associated construction material and/or debris in place before removal.

- Photograph the location of each battery or piece of associated debris after removal to document the clean-up.

\section{Contingency Plan}

The following activities will be performed if any soil staining is found associated with the batteries or construction debris:

- Collect biased surface and subsurface soil samples with hand tools to confirm the presence and define lateral extent of contamination at specific sites.

- Analyze site-specific soil samples for total RCRA metals.

- Mark the location where the soil samples were collected for laboratory analysis.

- $\quad$ Collect QC samples.

If contamination is confirmed by the laboratory analysis of the samples, the housekeeping clean-up of the Battery Dump Site will be reevaluated to include additional investigation activities and development of a CADD. 


\subsubsection{Septic Sludge Disposal Pits}

This section includes discussions of a Primary Investigation Plan and two Contingency Plans that may be implemented if site conditions warrant.

\section{Primary Investigation Plan}

The following activities, constituting the Primary Investigation Plan, will be conducted to characterize Septic Sludge Disposal Pit \#1 and Septic Sludge Disposal Pit \#2. The activities discussed in the Primary Investigation Plan assume location markers for the disposal pits are accurate and that septic sludge can be differentiated from backfill/capping material and native soil.

- Drill a "radiological background borehole" at an undisturbed location in the general area of the disposal pits. Field-screen samples for radiological activity at 3 -ft intervals to $60 \mathrm{ft}$ bgs for a total of 20 field-screening data points. These field-screening data will be used to establish radiological FSLs, as described in Section 3.3.1. Submit three samples with the highest FSRs to the laboratory for isotopic uranium, isotopic plutonium, and gamma spectrometry analysis.

- Drill an initial borehole through the center of each disposal pit and collect soil samples from every septic sludge layer encountered or at least every $10 \mathrm{ft}$. Field-screen samples for VOCs, $\mathrm{TPH}$, silver, and alpha/beta-emitting radionuclides. The minimum depth of these boreholes shall be $60 \mathrm{ft}$ bgs and will be advanced until FSRs are below FSLs for two consecutive boring intervals.

- Submit a minimum of three samples from each initial disposal pit borehole for laboratory analysis. The sample directly below the fill/native soil interface, from the basal sludge unit, and the first of two consecutive samples where FSRs are below FSLs will be submitted. The Site Supervisor may submit additional samples for laboratory analysis, based on FSRs and visual observation. Table 4-1 describes the material expected to be encountered and sampling criteria.

- Collect a sample from a septic sludge unit for bioassessment if VOC or TPH FSRs exceed FSLs, at the Site Supervisor's discretion.

- Collect a sample from native soil beneath the disposal pits for geotechnical analysis.

- Collect QC samples. 
Table 4-1

Sample Collection Locations and Sampling Criteria

\begin{tabular}{|c|c|c|}
\hline $\begin{array}{l}\text { Interval } \\
\text { (Feet [ft]) }\end{array}$ & Material Description & Criteria \\
\hline 0 to $4 \mathrm{ft}$ & $\begin{array}{l}\text { This should be the final capping } \\
\text { material (est. of } 4 \text { to } 6 \text { feet thick). }\end{array}$ & $\begin{array}{l}\text { Determine thickness of capping material and collect sample } \\
\text { where staining may exist or FSLs exceeded. If these } \\
\text { conditions are not present, collect a representative sample. } \\
\text { Location will be at Site Supervisor's discretion. }\end{array}$ \\
\hline 4 to $10 \mathrm{ft}$ & $\begin{array}{l}\text { Expect this material to be septic } \\
\text { sludge material (fairly soft and } \\
\text { retaining some characteristics of } \\
\text { septic sludge [i.e., medium brown } \\
\text { color]). }\end{array}$ & $\begin{array}{l}\text { Determine thickness of septic sludge material by identifying } \\
\text { the intermediate capping material below the sludge. Collect } \\
\text { sample where staining may exist or FSLs are exceeded. If } \\
\text { these conditions are not present, collect a representative } \\
\text { sample. Location will be at Site Supervisor's discretion. }\end{array}$ \\
\hline 10 to $13 \mathrm{ft}$ & $\begin{array}{l}\text { Expect this material to be } \\
\text { intermediate capping material (most } \\
\text { likely clean fill or cuttings). }\end{array}$ & $\begin{array}{l}\text { Determine thickness of intermediate capping material and } \\
\text { collect sample where staining may exist or FSLs are } \\
\text { exceeded. If these conditions are not present, collect a } \\
\text { sample from the upper six inches of the capping material. } \\
\text { Based on actual field conditions, the location may be } \\
\text { changed at Site Supervisor's discretion. }\end{array}$ \\
\hline 14 to $49 \mathrm{ft}$ & $\begin{array}{l}\text { Expect alternating layers of septic } \\
\text { sludge material and intermediate } \\
\text { capping material. }\end{array}$ & $\begin{array}{l}\text { For each layer of sludge material use the criteria discussed } \\
\text { above for the } 4 \text { - to } 10-\mathrm{ft} \text { interval. }\end{array}$ \\
\hline 50 to $60 \mathrm{ft}$ & $\begin{array}{l}\text { The bottom of the pit is expected at } \\
49 \mathrm{ft} \text {. Undisturbed native material } \\
\text { should be encountered. }\end{array}$ & $\begin{array}{l}\text { Collect a sample at } 1 \text { foot into the undisturbed material. } \\
\text { Collect additional samples every } 2 \text { or } 5 \text { feet (at discretion of } \\
\text { Site Supervisor) and/or at any obvious staining, or if FSLs } \\
\text { are exceeded. Sampling may cease if } 2 \text { consecutive } \\
\text { samples do not exceed FSLs. }\end{array}$ \\
\hline
\end{tabular}

If contamination is encountered in the initial disposal pit boreholes (i.e., FSRs exceed FSLs), step-out boreholes will be advanced per the following criteria:

- The first step-out borehole will be drilled at a 5 -ft center from the disposal pit. Subsequent step-out boreholes (if necessary [i.e., if contamination is encountered]) will be at 10 -ft centers. Continue step-out boreholes until no contamination is encountered.

- Advance step-out boreholes to a depth sufficient to sample the interval correlative to deepest contamination above FSLs encountered in the initial borehole.

- Collect soil samples from intervals correlative with contamination found in the initial borehole and/or at locations of obvious staining or contamination. Field-screen samples for VOCs, TPH, silver, and alpha/beta-emitting radionuclides. 
- Submit at least one sample from each step-out borehole for laboratory analysis. The sample(s) submitted will be from the depth(s) corresponding to contamination in the initial borehole. In addition, the Site Supervisor may submit additional samples for analysis based on FSRs and areas of obvious staining or contamination.

\section{Contingency Plan \#1}

The following activities will be performed if visual inspection of borehole returns shows no differentiation or layering (i.e., uniform color and texture):

- Field-screen soil samples for VOCs, TPH, silver, and alpha/beta-emitting radionuclides every $10 \mathrm{ft}$ to a depth of $60 \mathrm{ft}$ bgs (or deeper at Site Supervisor's discretion).

- Submit a minimum of three samples from each borehole for laboratory analysis. The sample directly below the fill/native soil interface (if identified), the sample with the highest FSR, and the first of two consecutive samples where FSRs are below FSLs will be submitted. If the fill/native soil interface is not identified, this sample will be replaced with another sample at the discretion of the Site Supervisor. The Site Supervisor may submit additional samples for laboratory analysis, based on FSRs and visual observation.

- Collect sample for bioassessment if the FSL for VOCs or TPH is exceeded, at Site Supervisor's discretion.

- Collect sample from native soil beneath disposal pit for geotechnical analysis.

- Collect QC samples.

- If step-out borings are required, they will be advanced as described above in the Primary Investigation Plan.

This investigation strategy will allow the nature and extent of contamination associated with each CAS to be determined. In general, the contents of each location and the underlying soil will be investigated until two consecutive soil samples with contamination concentrations below appropriate FSLs are obtained. If contamination is more extensive than anticipated, the maximum investigation depth will be limited by the capability of the selected drilling method. If this occurs, the investigation will be reevaluated. 


\section{Contingency Plan \#2}

These activities will be executed if the previously identified location of Septic Sludge Disposal Pit \#1 is inaccurate and/or does not contain septic tank sludge.

The preliminary assessment and previous geophysical investigations of the Septic Sludge Disposal Pits were unable to determine the exact locations of the disposal pits. The Site Supervisor and/or the Site Geologist will inspect the material recovered from Septic Sludge Disposal Pit \#1 and determine if undisturbed native material or septic tank sludge material is being encountered.

If an undisturbed native stratigraphic interval is encountered at the location believed to be Septic Sludge Disposal Pit \#1, drilling activities will be stopped. At a minimum, the boring shall reach $40 \mathrm{ft}$ bgs before terminating drilling activities at this location.

Field activities will transfer to the previously identified location of Septic Sludge Disposal Pit \#2 and executed as discussed in the Primary Investigation Plan or Contingency Plan \#1 (as appropriate). If an undisturbed native stratigraphic interval is encountered at the Septic Sludge Disposal Pit \#2 location (after drilling to a minimum depth of $40 \mathrm{ft} \mathrm{bgs}$ ), investigative field activities will be terminated, DOE/NV and NDEP notified, and the investigation reevaluated.

\subsection{Sampling Criteria}

All sampling activities for CAU 409 will be conducted in compliance with the requirements of the Industrial Sites QAPP (DOE/NV, 1996c) and this CAIP. Section 4.4.1 through Section 4.4.6 provide details on the type of sample collection that will be performed during the field investigation. The CAS-specific investigation strategy and proposed sampling locations are provided in Section 4.3.

Records will be maintained for a visual classification of the soil from boreholes, field-screening measurements, and all other pertinent data. Relevant and required sampling information (e.g., date, time, sample interval) will be documented in accordance with the Industrial Sites QAPP. Approved chain of custody procedures (DOE/NV, 1994a) will be followed to ensure sample integrity. 
All equipment which contacts soil to be sampled will be decontaminated in accordance with written, approved, and controlled procedures. All sampling equipment will be decontaminated prior to each sampling event to minimize the potential for cross-contamination of samples from different locations.

All samples will be field screened (except those that may be collected at the Battery Dump Site, as described in Section 4.3.1) for VOCs, TPH, silver, and alpha/beta-emitting radionuclides and a limited number of these samples will be submitted to the off-site laboratory. Samples to be analyzed will be selected based on the results of field screening and minimum sampling requirements. The actual number of samples analyzed will depend on decisions made in the field.

\subsubsection{Environmental Samples}

Environmental samples collected for laboratory analyses will consist of unused media. Samples targeted for VOC analysis will be given highest priority when being collected. Samples with no volatilization concerns will be collected with priority given to those with the shortest holding times.

Samples collected from the disposal pits will be analyzed for total VOCs, total SVOCs, total RCRA metals, PCBs, TPH (GDRO), isotopic uranium, and isotopic plutonium. In addition, selected samples will be analyzed for gamma spectrometry to assist in waste management decisions. If samples are collected from the Battery Dump Site, they will be analyzed for total RCRA metals. All samples submitted to the laboratory will be analyzed in accordance with Appendix C.

\subsubsection{Quality Control Samples}

Quality control samples will be collected as required by the Industrial Sites QAPP (DOE/NV, 1996c). These samples will include trip blanks, equipment blanks, source blanks, field blanks, field duplicates, and matrix spike/matrix spike duplicates (MS/MSD) samples. Quality control samples will be analyzed for those parameters listed in Table A.2-2 with the exception that trip blanks will only be analyzed for VOCs, and QC samples that may be collected at the Battery Dump Site will only be analyzed for total RCRA metals. With the exception of MS/MSD, QC samples will be submitted to the laboratory blind. Additional QC samples may be submitted at the discretion of the Site Supervisor. 


\subsubsection{Background Samples}

Background data for radionuclides will be collected by drilling a boring in an undisturbed area approximately $50 \mathrm{ft}$ to $100 \mathrm{ft}$ from the disposal pits. Samples will be field screened for radiological activity every $3 \mathrm{ft}$ from the surface to $60 \mathrm{ft}$ bgs. These field-screening data will be used to establish FSLs as described in Section 3.3.1. Three samples will be analyzed to confirm the background data collected and to assist in waste management decisions. Background data on RCRA metals have been previously generated for Area 3 and Area 9 during past investigations and will be used to evaluate data to be presented in the CADD.

\subsubsection{Geotechnical Samples}

In addition to environmental samples, at least one geotechnical sample will be collected at the Site Supervisor's discretion from the Septic Sludge Disposal Pits to characterize the geologic and hydrologic properties of soils. Analysis of geotechnical parameters listed in Table 4-2 will be performed by an off-site laboratory. The methods shown are minimum standards, and other equivalent or superior testing methods may be used.

Table 4-2

Geotechnical Analyses

\begin{tabular}{|c|c|}
\hline Analysis & Method \\
\hline Initial moisture content & ASTM $^{\mathrm{a} D} 2216$ \\
\hline Dry bulk density & $\mathrm{EM}^{\mathrm{b}}-1110-2-1906$ \\
\hline Calculated porosity & $\mathrm{EM}^{\mathrm{b}}-1110-2-1906$ \\
\hline Saturated hydraulic conductivity & $\mathrm{ASTM}^{\mathrm{a} D} 5084$ \\
\hline Unsaturated hydraulic conductivity & van Genuchten $^{\mathrm{c}}$ \\
\hline Particle-size distribution & $\mathrm{ASTM}^{\mathrm{a} D}$ 422-63(90) \\
\hline Water-release (moisture retention) curve & $\mathrm{ASTM}^{\mathrm{a} D}$ 3152 \\
\hline
\end{tabular}

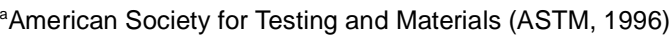

bU.S. Army Corps of Engineers (USACE, 1970)

${ }^{c}$ van Genuchten, 1980

\subsubsection{Bioassessment Samples}

One or more bioassessment samples will be collected, at the discretion of the Site Supervisor, if FSRs detect VOCs or TPH significantly above FSLs. Bioassessment is a series of tests designed to evaluate the physical, chemical, and microbiological characteristics of soil. These tests include determination 
of nutrient availability, soil $\mathrm{pH}$, microbial population density, and the availability of the microbial population to grow under enhanced conditions. These samples will be collected within brass sleeves (or other container, as appropriate to the sample collection methodology) to preserve the natural physical characteristics of the soil. The data will be used in the evaluation of alternatives in the CADD.

\subsubsection{Waste Management Samples}

To characterize waste generated during this investigation, all soil samples submitted to the off-site laboratory will be analyzed for gamma spectrometry. The laboratory will also be required to generate and hold leachate from samples to be used for potential Toxicity Characteristic Leaching Procedure (TCLP) for VOCs and SVOCs . In addition, TCLP for metals may also be requested to assist in waste management decisions. Rinsate samples from investigation activities will be analyzed for isotopic uranium, isotopic plutonium, gross alpha, gross beta, and gamma spectrometry. 


\subsection{Waste Management}

Management of IDW will be based on regulatory requirements, field observations, field screening, and laboratory analysis of CAU 409 investigation samples. Decontamination activities will be performed according to approved contractor procedures as specified in the field sampling instructions and as appropriate for the COPCs likely to be identified within each CAS.

Waste other than soil is potentially contaminated waste only by virtue of contact with potentially contaminated media. Therefore, sampling and analysis of IDW, separate from analyses of site characterization samples, may not be necessary. However, rinsate or other samples may be taken to support waste management activities. The data generated as a result of site characterization and process knowledge will be used, whenever possible, to assign the appropriate waste type (i.e., solid waste (nonhazardous), hydrocarbon, hazardous, low-level radioactive waste [LLW], or mixed) to the IDW. Solid waste (nonhazardous), hydrocarbon, hazardous, radioactive, and/or mixed waste, if generated, will be managed and disposed of in accordance with DOE Orders, U.S. Department of Transportation (DOT) regulations, RCRA regulations, State of Nevada requirements and agreements, and permits between DOE and NDEP.

\subsection{Waste Minimization}

Corrective action investigation activities have been planned to minimize IDW generation.

Decontamination activities will only use as much water as necessary to decontaminate equipment and personnel to minimize the amount of rinsate generated. Disposable sampling equipment, decontamination rinsate, and PPE will be segregated to the greatest extent possible to minimize the generation of hazardous, radioactive, and/or mixed waste.

\subsection{Potential Waste Streams}

Process knowledge indicates the potential for hazardous and/or radioactive materials to be present at CAU 409. There is a potential that solid/sanitary (nonhazardous), LLW, hazardous, mixed, and 
hydrocarbon waste may be generated during field activities. Specific waste materials generated during the investigation may include, but are not limited to, the following:

- Decontamination rinsate

- Potentially contaminated disposable sampling equipment (e.g., plastic, paper, sample containers, aluminum foil, trowels, hand augers)

- PPE potentially contaminated during field activities

For administrative purposes, waste will be segregated into multiple waste streams: containerized soil, solid waste (nonhazardous), potentially contaminated PPE, and decontamination rinsate. Further segregation may be implemented within each waste stream, as appropriate.

\subsection{Investigation-Derived Waste Management}

Waste will be managed according to the requirements identified in Section 5.3 of the Leachfield Work Plan until laboratory analyses are received and a final waste determination is made. Applicable waste management regulations and requirements are listed in Table 5-1.

Table 5-1

Waste Management Regulations and Requirements

\begin{tabular}{|c|c|c|}
\hline Waste Type & Federal Regulation & Additional Requirements \\
\hline \hline Solid/Sanitary (Nonhazardous) & NA & $\begin{array}{c}\text { NRS } 444.440-444.620^{\mathrm{a}} \\
\text { NAC } 444.570-444.7499^{\mathrm{b}}\end{array}$ \\
\hline Hydrocarbon & NA & NAC 445A.2272 \\
\hline Hazardous & RCRA & $\begin{array}{c}\text { NRS } 459.400-459.600^{\mathrm{d}} \\
\text { NAC } 444.850-444.8746^{\mathrm{e}} \\
\text { POC }^{\mathrm{f}}\end{array}$ \\
\hline Low-Level Radioactive & NA & DOE Orders and NTSWAC \\
\hline Mixed & RCRA & NTSWAC $^{\mathrm{g}}$ POC $^{\mathrm{f}}$ \\
\hline
\end{tabular}

NA $=$ Not Applicable

${ }^{\mathrm{a}}$ Nevada Revised Statutes (NRS, 1998a)

${ }^{\mathrm{b}}$ Nevada Administrative Code (NAC, 1999a)

${ }^{\mathrm{C}}$ Nevada Administrative Code (NAC, 1999c)

${ }^{\mathrm{d} N e v a d a}$ Revised Statutes (NRS, 1998b)

${ }^{\mathrm{e}}$ Nevada Administrative Code (NAC, 1999b)

${ }^{\dagger}$ Nevada Test Site Performance Objective for the Certification of Nonradioactive Hazardous Waste (BN, 1995)

${ }^{9}$ Nevada Test Site Waste Acceptance Criteria, Rev. 2 (DOE/NV, 1999) 
Management requirements for solid waste (nonhazardous), LLW, hydrocarbon, hazardous, and mixed waste are discussed further in the following sections. All IDW generated will be managed according to mixed waste requirements until a waste determination is made.

Any IDW generated during this investigation will be segregated by waste stream and placed in DOT-compliant packages appropriate for the type and amount of waste generated.

\subsubsection{Solid Waste (Nonhazardous)}

Solid waste will be contained in plastic bags, dumpsters, or packages and will be disposed of in a solid waste management unit.

\subsubsection{Low-Level Radioactive Waste}

Low-level radioactive waste, if generated, will be managed and characterized in accordance with DOE Orders and the requirements of the Nevada Test Site Waste Acceptance Criteria (NTSWAC) (DOE/NV, 1999). Characterization will be based on laboratory results, field screening, process knowledge, or a combination thereof. Potentially contaminated IDW, such as PPE, will be placed in plastic bags, containerized, and marked with the date and associated sample location. The plastic bags and any other LLW, such as containerized soil, will be placed in marked packages meeting DOT specifications (49 Code of Federal Regulations [CFR] 172 [CFR, 1998]) and locked or fitted with tamper-indicating devices. The drums will be staged at a designated Radioactive Materials Area pending disposal in accordance with NTSWAC requirements (DOE/NV, 1999). Drums will be marked "Radioactive Material Pending Analysis" until a final waste characterization can be made.

Rinsate that is potentially contaminated with radioactive material will be collected in packages meeting DOT specifications (49 CFR 172) (CFR, 1998). Gross alpha, gross beta, gamma spectrometry, isotopic uranium, and isotopic plutonium analysis will be performed on rinsate samples (a composite sample can be collected from up to three drums of rinsate) and the results will be used to determine final disposition. Additionally, the soil characterization results may be applied to the rinsate as part of the determination of final disposition. 
Any waste to be disposed of in LLW landfills at the NTS will be characterized in accordance with the requirements of the NTSWAC and the contractor-specific waste certification program plan and implementing procedures.

\subsubsection{Hazardous Waste}

Suspected hazardous waste will be managed in accordance with the procedures outlined in this section, which are based on RCRA and Nevada hazardous waste regulations. Such waste will be placed in properly marked packages meeting DOT specifications as per 49 CFR 172 (CFR, 1998). Container markings and field records will allow wastes to be traceable back to the source. Additionally, waste may be directly sampled for characterization purposes. The type of container used will be appropriate for the particular waste in storage as specified in 40 CFR 265.172 (CFR, 1999a). No incompatible waste is expected to be generated; however, if incompatible waste is encountered in the field, it will be managed in accordance with 40 CFR 265.177 (CFR, 1999b).

Hazardous waste will be characterized in accordance with the requirements of 40 CFR 261 (CFR, 1999c). Characterization will be based on analytical data, field-screening results, process knowledge, or a combination thereof. Containers holding wastes pending characterization will be identified with "Hazardous Waste Pending Analysis" markings until the regulatory status can be determined. Depending on the nature and amount of waste generated, waste management control areas may be established, such as a Satellite Accumulation Area (SAA) or Hazardous Waste Accumulation Area (HWAA).

Hazardous waste will not be stored at the site of generation for more than 90 days unless accumulated in a SAA in accordance with 40 CFR 262.34 (CFR, 1999d). Hazardous waste will be shipped to a permitted hazardous waste treatment, storage, or disposal facility before the expiration of the 90-day storage limit. The waste will be transported by a licensed hazardous waste hauler and accompanied by a Uniform Hazardous Waste Manifest, in accordance with DOT shipping requirements. A copy of the manifest will be provided to the NDEP in accordance with state regulatory requirements.

At a minimum, the characterization of hazardous waste (which may include rinsate), generated during investigative activities, will comply with the NTS Performance Objective for Certification of Nonradioactive Hazardous Waste (BN, 1995). 


\subsubsection{Mixed Waste}

Mixed waste, if generated, will be managed in accordance with RCRA (CFR, 1999c) and NAC regulations (NAC, 1999d), as well as DOE requirements for radioactive waste. Where there is a conflict in regulations or requirements, the most stringent will apply. For example, the 90-day accumulation limit and weekly inspections required by RCRA regulations will be applied to mixed waste, even though it is not required for radioactive waste. Conversely, while RCRA does not require traceability, the NTS waste acceptance program for LLW does; therefore, records allowing traceability will be maintained. Containers holding wastes pending characterization will be identified with "Awaiting Analysis" markings until the regulatory status can be determined.

In general, mixed waste will be handled in the same manner as hazardous waste, but with the added LLW management program requirements. Mixed waste will be transported to the NTS transuranic waste storage pad pending treatment or disposal. Mixed waste with hazardous constituents that are below land disposal restrictions may be disposed of at the Area 5 Radioactive Waste Management Site. Mixed waste not meeting land disposal restrictions will remain at the transuranic waste storage pad pending development of a treatment plan in accordance with the requirements of the 1995 Mutual Consent Agreement between DOE and the State of Nevada (NDEP, 1995).

At a minimum, the characterization of mixed waste (which may include rinsate), generated during investigative activities, will comply with the NTS Performance Objective for Certification of Nonradioactive Hazardous Waste (BN, 1995).

\subsubsection{Hydrocarbon Waste}

The action level for soil contaminated with hydrocarbons is $100 \mathrm{mg} / \mathrm{kg}$ in the state of Nevada (NAC, 1999c). Containerized soil and associated IDW with TPH levels above $100 \mathrm{mg} / \mathrm{kg}$ shall be managed as hydrocarbon waste and shall be disposed of in accordance with all applicable regulations in a hydrocarbon landfill.

\subsection{Analysis Required for the Disposal of IDW}

Additional analytical data may be required to characterize the IDW, as discussed in Section 4.4.6. These analyses will support waste classification to meet waste acceptance criteria prior to disposal at 
on-site NTS and off-site locations. For instance, gamma spectrometry analysis is required to characterize waste which will be transported to the NTS. Additional analyses may include TCLP VOC, TCLP SVOC, and TCLP RCRA metals. Each of the CASs have been reviewed to ensure that sufficient analyses to support IDW disposal have been planned. Rinsate generated during this site investigation will be analyzed for isotopic uranium, isotopic plutonium, gross alpha, gross beta, and gamma spectrometry. 


\subsection{Duration and Records Availability}

\subsection{Duration}

After submittal of the Final CAIP for CAU 409 to NDEP (FFACO milestone deadline of November 30, 2000), the following is a tentative schedule of activities (in calendar days):

- Day 0: Preparation for field work will begin.

- Day 45: The field work, including field screening and sampling will begin. Samples will be shipped to meet laboratory holding times.

- Day 90: The field work will be completed and unvalidated data will be returned from the analytical laboratory.

- Day 120: The quality-assured analytical sample data will be available for NDEP review.

- The FFACO date for the CADD to NDEP is September 28, 2001.

\subsection{Records Availability}

Historic information and documents referenced in this plan are retained in the DOE/NV project files in Las Vegas, Nevada, and can be obtained through written request to the DOE/NV Project Manager. This document is available in the DOE public reading rooms located in Las Vegas and Carson City, Nevada, or by contacting the DOE Project Manager. The NDEP maintains the official Administrative Record for all activities conducted under the auspices of the FFACO. 


\subsection{References}

ASTM, see American Society of Testing Materials.

American Society for Testing and Materials. 1996. Section 04.08 and 04.09, "Construction." In Annual Book of ASTM Standards. Philadelphia, PA.

Atlan-Tech. 1992. Environmental Monitoring Report for the Proposed Ward Valley, California LLRW Facility. Rosewall, GA: Atlan-Tech Inc.

BN, see Bechtel Nevada.

Bechtel Nevada. 1995. Nevada Test Site Performance Objective for Certification of Nonradioactive Hazardous Waste, G-E11/96.01, Rev. 0. Las Vegas, NV.

CFR, see Code of Federal Regulations.

Code of Federal Regulations. 1998. 49 CFR 172, "Hazardous Materials Table, Special Provisions, Hazardous Materials Communications, Emergency Response Information, and Training Requirements." Washington, DC: U.S. Government Printing Office.

Code of Federal Regulations. 1999a. 40 CFR 265.172, "Compatibility of Waste with Containers." Washington, DC: U.S. Government Printing Office.

Code of Federal Regulations. 1999b. 40 CFR 265.177, "Special Requirements for Incompatible Waste." Washington, DC: U.S. Government Printing Office.

Code of Federal Regulations. 1999c. 40 CFR 261, "Identification and List of Hazardous Waste." Washington, DC: U.S. Government Printing Office.

Code of Federal Regulations. 1999d. 40 CFR 262.34, "Accumulation Time." Washington, DC:

U.S. Government Printing Office.

DOE, see U.S. Department of Energy.

DOE/NV, see U.S. Department of Energy, Nevada Operations Office.

Elliston, J. 2000. Record of Telecon with B. McCall (ITLV) regarding the operational history of the Septic Tank Systems in Area 3, 3 May. Las Vegas, NV: IT Corporation.

EPA, see U.S. Environmental Protection Agency.

FFACO, see Federal Facility Agreement and Consent Order. 
Federal Facility Agreement and Consent Order. 1996 (as amended). Agreed to by the State of Nevada, the U.S. Department of Energy, and the U.S. Department of Defense.

IT, see IT Corporation.

IT Corporation. 1991. Tonopah Test Range Septic Tank Sampling and Analysis Final Report. Albuquerque, NM.

IT Corporation. 1997. Initial Surface Geophysical Survey Report For The Tonopah Test Range Environmental Restoration Sites, Vol. 1 of 2, ITLV10972--93. Las Vegas, NV.

IT Corporation. 2000. Health and Safety Plan, March, ITLV13052--105. Las Vegas, NV.

McArthur, R.D., and F.L. Miller, Jr. 1989. Off-Site Radiation Exposure Review Project (ORERP), Phase II Soil Program, DOE/NV/10384-23. Las Vegas, NV: Desert Research Institute.

NAC, see Nevada Administrative Code.

Nevada Administrative Code. 1999a. NAC 444.570 - 444.7499, "Solid Waste Disposal." Carson City, NV.

Nevada Administrative Code. 1999b. NAC 444.850 - 444.8746, "Disposal of Hazardous Waste." Carson City, NV.

Nevada Administrative Code. 1999c. NAC 445A.2272, "Contamination of Soil: Establishment of Action Levels." Carson City, NV.

Nevada Administrative Code. 1999d. NAC 444, "Sanitation." Carson City, NV: Nevada Division of Environmental Protection.

NDEP, see Nevada Division of Environmental Protection.

Nevada Division of Environmental Protection. 1995. "Mutual Consent Agreement Between the State of Nevada and the Department of Energy for the Storage of Low-Level Land Disposal Restricted Mixed Waste." Transmittal from P. Liebendorfer (NDEP) to D. Elle (DOE/NV), 7 June. Carson City, NV.

NRS, see Nevada Revised Statutes.

Nevada Revised Statutes. 1998a. NRS 444.440 - 444.620, "Collection and Disposal of Solid Waste." Carson City, NV.

Nevada Revised Statutes. 1998b. NRS 459.400 - 459.600, "Disposal of Hazardous Waste." Carson City, NV. 
Remote Sensing Laboratory. 1999. Aerial Photograph Number 9997-28, 14 March. Nellis Air Force Base, NV: Photo Archive Library.

SNL, see Sandia National Laboratories.

Sandia National Laboratories. 1994. Septic Tank Monitoring Report, Tonopah Test Range and Nevada Test Site, June. Albuquerque, NM.

USACE, see U.S. Army Corps of Engineers.

U.S. Army Corps of Engineers. 1970. "Laboratory Soils Testing.” In Engineering Manual 1110-2-1906, Appendix II. Washington, DC.

U.S. Department of Energy, Nevada Operations Office. 1994a. Project Management Plan, Rev. 0. Las Vegas, NV.

U.S. Department of Energy, Nevada Operations Office. 1994b. Resource Conservation and Recovery Act Facility Investigation Work Plan, U.S. Department of Energy Environmental Restoration Sites, Tonopah Test Range, Nevada, Draft, Vol. 1 and 2, May. Las Vegas, NV.

U.S. Department of Energy, Nevada Operations Office. 1994c. Tonopah Test Range Site Priority Ranking Model, September. Las Vegas, NV.

U.S. Department of Energy, Nevada Operations Office. 1996a. Corrective Action Unit Work Plan, Tonopah Test Range, Nevada. Las Vegas, NV.

U.S. Department of Energy, Nevada Operations Office. 1996b. Final Environmental Impact Statement for the Nevada Test Site and Off-Site Locations in the State of Nevada, DOE/EIS 0243. Las Vegas, NV.

U.S. Department of Energy, Nevada Operations Office. 1996c. Industrial Sites Quality Assurance Project Plan, Nevada Test Site, Nevada, Rev. 1, DOE/NV--372. Las Vegas, NV.

U.S. Department of Energy, Nevada Operations Office. 1998. Work Plan for Leachfield Corrective Action Units: Nevada Test Site and Tonopah Test Range, Nevada, Rev. 1, DOE/NV--514. Las Vegas, NV.

U.S. Department of Energy, Nevada Operations Office. 1999. Nevada Test Site Waste Acceptance Criteria (NTSWAC), Rev. 2. Las Vegas, NV.

U.S. Department of Energy, Nevada Operations Office. 2000a. Corrective Action Decision Document for Corrective Action Unit 428: Area 3 Septic Waste Systems 1 and 5, Tonopah Test Range, Nevada, Rev. 0, DOE/NV--587. Las Vegas, NV. 
U.S. Department of Energy, Nevada Operations Office. 2000b. Sectored Clean-up Work Plan for Housekeeping Category Waste Sites, Rev. 0, DOE/NV--579. Las Vegas, NV.

U.S. Environmental Protection Agency. 1994. Guidance for the Data Quality Objectives Process, EPA QA/G-4. Washington, DC.

U.S. Environmental Protection Agency. 1999. Memo from S.J. Smucker to table mailing list regarding Region 9 Preliminary Remediation Goals (PRGs), 1 October. San Francisco, CA.

van Genuchten, M. 1980. "A Closed Form Equation for Predicting the Hydraulic Conductivity of Unsaturated Soils.” In Soil Science Society of America Journal, 44: 892-898. El Cerritos, CA. 
Appendix A

\section{Data Quality Objectives Worksheets}




\section{A.1.0 Introduction}

The information developed as part of the DQO process is presented in this appendix. The DQO Process is a strategic planning approach used to prepare for data collection activities. It provides a systematic procedure for defining when to collect samples, the tolerable level of decision errors for the investigation, and how many samples to collect. These DQOs will drive the investigative activities to be performed at CAU 409 and are the basis for the CAIP.

Discussions in this Appendix include:

- $\quad$ Problem Statement for CAU 409

- DQO Process Overview

- Conceptual Model (including COPCs)

- Decisions and Inputs

- Field Activity Strategies

- Decision Rules and

- Decision Errors

CAU 409 is composed of the following three CASs:

- CAS RG-24-001-RGCR, Battery Dump Site

- CAS TA-53-001-TAB2, Septic Sludge Disposal Pit (hereafter referred to as Septic Sludge Disposal Pit \#1)

- CAS TA-53-002-TAB2, Septic Sludge Disposal Pit (hereafter referred to as Septic Sludge Disposal Pit \#2)

\section{A.1.1 Problem Statement}

\section{CAS RG-24-001-RGCR, Battery Dump Site}

The Battery Dump Site is a remote location where lead-acid batteries were stockpiled and later discarded when the batteries were dead. These discarded batteries and associated construction material/debris could potentially be a source of contamination. This CAS is included in the "Housekeeping Site" functional category in the FFACO, 1996. Therefore, this CAS will be addressed within the Sectored Clean-up Work Plan for Housekeeping Category Waste Sites (DOE/NV, 2000). 


\section{CAS TA-53-001-TAB2 and CAS TA-53-002-TAB2, Septic Sludge Disposal Pits}

Potentially hazardous wastes were discharged to the septic waste systems in Area 3 of the TTR and may also be contained in the septic tank sludge that was disposed of at the two Septic Sludge Disposal Pits. Existing information about the nature and extent of contamination is insufficient to evaluate and select preferred corrective actions for the Septic Sludge Disposal Pits.

These sites will be investigated based on DQOs developed by representatives of NDEP and DOE/NV. This investigation will determine if COPCs are present and if concentrations exceed regulatory levels in soils underlying and immediately surrounding the Septic Sludge Disposal Pits and the Battery Dump Site. If COPCs are detected, the lateral and vertical extent of contamination will be determined. This investigation will focus on collection of data adequate to close the sites under NDEP, RCRA, and DOE requirements.

\section{A.1.2 DQO Process Overview}

The DQO Process is a strategic planning approach used to:

- Prepare for data collection activities.

- Provide a mechanism to document activities and decisions.

- Communicate the data collection design to the participants in CAU 409.

This communication among all the participants is one of the central tenets of quality management practices, thereby enabling the data users and relevant technical experts to participate in data collection planning and to specify their particular needs prior to data collection. Implementation of this communication among the participants is accomplished by holding a formal DQO Kickoff Meeting (required by the FFACO). Table A.1-1 lists the participants present at the CAU 409 DQO Kickoff Meeting.

Through the DQO Kickoff Meeting, data users are encouraged to clarify vague objectives and to limit the number of decisions that will be made. Through the DQO process, the decision performance requirements of the data collected, appropriate for the intended uses of the data, are to be defined. The performance requirements will be defined by considering the consequences of decision errors and then placing tolerable limits on the probability that the data will mislead the 
Table A.1-1

DQO Kickoff Meeting Participants

\begin{tabular}{|l|l|l|c||}
\hline \multirow{2}{*}{ Proposed Participants } & Affiliation & \multicolumn{1}{|c|}{ Role } & Meeting Date \\
\cline { 4 - 5 } & & & $\begin{array}{c}\text { Kickoff Meeting } \\
\mathbf{0 4 / 2 7 / 2 0 0 0}\end{array}$ \\
\hline \hline Kevin Cabble & DOE/NV & Task Manager & $\mathbf{X}$ \\
\hline Lydia Coleman & ITLV & Analytical/Reg Support & $\mathbf{X}$ \\
\hline Brad Jackson & ITLV & IS Project Manager & $\mathbf{X}$ \\
\hline Syl Hersh & ITLV & QA Oversight & $\mathbf{X}$ \\
\hline Mark Holmes & ITLV & Technical Execution & $\mathbf{X}$ \\
\hline Gregg Raab & NDEP & Task Manager & $\mathbf{X}$ \\
\hline Allison Urbon & BN & Task Manager & $\mathbf{X}$ \\
\hline James Traynor & BN & Task Manager & $\mathbf{X}$ \\
\hline Trenton Richards & ITLV & IS Task Manager & $\mathbf{X}$ \\
\hline Milinka Watson-Garrett & ITLV & Analytical/Reg Support & $\mathbf{X}$ \\
\hline Jeanne Wightman & ITLV & QA & $\mathbf{X}$ \\
\hline \hline
\end{tabular}

BN - Bechtel Nevada

DOE/NV - U.S. Department of Energy, Nevada Operations Office

ITLV - IT Corporation, Las Vegas

NDEP - Nevada Division of Environmental Protection

decision makers into committing a decision error. A sampling design can then be generated to provide the most efficient method for controlling decision errors and satisfying the DQOs.

The goal to be reached through the DQO process is to establish the quantity and quality of environmental data required to support corrective action decisions for CAU 409. To attain this goal, the following topics are considered:

- Types of data expected to be utilized

- Types of data expected to be collected

- End users of data

- What data quality is to be expected

- Decision makers

- Expectations to close the sites under NDEP, RCRA, and DOE requirements 
The process ensures the information collected can be used to technically defend the chosen corrective action for each of the three CASs in CAU 409. The roles and expectations that will ensure the DQO process is successful are discussed in the following paragraphs.

\section{Types of Data to be Utilized}

From the Preliminary Assessment (PA) to the CAIP, data collected will have different end users and the expectations of what that data will determine will be based on the role of the end user. The first type of data used in this process is PA data which includes historic data and current physical site condition data. The end users of the PA data may determine if additional PA-type data is needed.

Field data will be collected at the time of the investigation and used in the corrective action decision. The end users of the data are those team members in the field and the decision makers.

Analytical data will be used in the final characterization of the site and to decide which corrective actions will be implemented. The end users of the data are the Industrial Sites (IS) Project Manager (PM), IS Task Manager (TM), the NDEP and DOE/NV decision makers, and the TM for the remediation contractor.

\section{Types of Data Expected to be Collected}

Soil/sludge samples will be collected from the Septic Sludge Disposal Pits. Both field-screening data and analytical data related to the samples will be collected and evaluated. Analytic data will address COPCs that are radioactive in nature and those that are not radioactive.

\section{End Users of Data}

Field-screening data will be used by the Site Supervisor (SS), Field Geologist/Engineer/Scientist, and the Health Physics Group. They will use the data to determine where and how many samples to collect and which samples are to be sent to laboratories for analysis; ensure that samples are properly labeled, handled, and transported; and confirm that appropriate health and safety controls are being implemented at the investigation site. 
All analytical data received from laboratories will be used by many different groups involved in the process of developing an appropriate corrective action to address these CASs. Analytical Services will validate the data. The Quality Processes group will ensure that the quantity and quality of the data collected is adequate and the analytical results are properly presented in the CADD. The IS PM and TMs, DOE/NV TM, and NDEP TM will use the data to evaluate remedial alternatives and select an appropriate corrective action. Depending on the remedial alternative selected, the remediation contractor TM may use the data to implement the selected remedial alternative.

\section{What Data Quality is to be Expected}

The quality of the data will be sufficient to ensure adequate data validation. Sampling and analytical procedures should result in data that meets the requirements of precision, accuracy, representativeness, completeness, and comparability as stated in the IS QAPP (DOE/NV, 1996c).

Additionally, the data quality will be sufficient to characterize the investigation-derived waste and the contaminated media in order to determine if the material can meet the waste acceptance criteria of potential disposal facilities.

\section{Decision Makers}

Decisions are made at many stages of this process. Data collected in the PA will be used by the IS TMs, DOE/NV TM, and NDEP TM to develop the CAIP strategy. Decision makers at the field investigation site include the TM, SS, and/or CAU Lead. Decision makers during the preparation of the Final CAIP document will use the analytical data as well as the field data. The decision makers at this stage include the IS PM, TM, DOE/NV TM, NDEP TM, and the remediation contractor TM.

\section{What is to be expected to close the sites under NDEP, RCRA, and DOE requirements}

The data will provide sufficient and reliable information to identify, evaluate, and technically defend the chosen corrective action. This chosen corrective action will meet the NDEP, RCRA, and DOE requirements at a minimum. 
Unless otherwise required by the results of this DQO and stated in the CAIP, this investigation will adhere to the IS QAPP (DOE/NV, 1996c). Clean-up activities associated with the Battery Dump Site Investigation will adhere to the Sectored Clean-up Work Plan For Housekeeping Category Waste Sites (DOE/NV, 2000), hereafter referred to as the Sectored Clean-up Work Plan. Clean-up activities at the two Septic Sludge Disposal Pits will adhere to the Work Plan for Leachfield Corrective Action Units: Nevada Test Site and Tonopah Test Range, Nevada (DOE/NV, 1998), hereafter referred to as the Leachfield Work Plan. 


\section{A.2.0 Conceptual Models}

Conceptual models of the CASs that make up CAU 409 are discussed in the following paragraphs. The models will include suspected sources of contamination, COPCs, affected media, and potential routes of migration. This effort, in addition to assisting in identifying locations where sampling is necessary, will also assist in the identification and support of corrective action decisions for the CAU 409 CASs.

\section{A.2.1 Battery Dump Site}

In addition to the spent/dead batteries, the Battery Dump Site includes associated construction material and/or debris.

\section{A.2.1.1 Contaminants of Potential Concern}

No COPCs have been identified or associated with CAS RG-24-001-RGCR. Clean-up of this CAS is being handled as a housekeeping site; therefore, the work will be performed under the Sectored Clean-up Work Plan.

\section{A.2.1.2 Physical Setting}

Located near Cactus Peak, a communications repeater station was battery powered because of its remote location. Based on PA investigations, it appears new batteries were placed in a corrugated metal pipe, approximately $2 \mathrm{ft}$ in diameter and $2 \mathrm{ft}$ tall, and covered with a wood lid. The wood lid was attached to the metal pipe with a chain. Spent/dead batteries were discarded in the area around the corrugated metal pipe. In addition to the batteries, associated construction material/ debris is scattered around the metal pipe.

An outline of site-specific elements of the conceptual model for the Battery Dump Site is provided in Table A.2-1.

\section{A.2.2 Septic Sludge Disposal Pits}

These disposal pits are augured holes approximately $3 \mathrm{ft}$ in diameter and assumed to be approximately $50 \mathrm{ft}$ deep. Septic Sludge Disposal Pit \#1 is located $75 \mathrm{ft}$ south of Septic Sludge Disposal Pit \#2. Figure A.2-1 provides a diagrammatic sketch of the disposal pits. 
Table A.2-1

Conceptual Model for CAS RG-24-001-RGCR, Battery Dump Site

\begin{tabular}{|c|c|c|}
\hline $\begin{array}{l}\text { Conceptual Model } \\
\text { Element }\end{array}$ & Assumptions & Source \\
\hline \multirow[t]{2}{*}{ Physical Setting } & $\begin{array}{l}\text { The location of the repeater tower is approximately } \\
2.4 \text { miles west of the junction of Cactus Peak Road and } \\
\text { Repeater Road. The batteries, mast, stakes, and wire } \\
\text { are located approximately } 0.1 \text { mile west of Cactus Peak } \\
\text { Road in a saddle between two rocky outcrops. }\end{array}$ & (IT, 1998a) \\
\hline & Currently no evidence of staining of soil on surface. & $(\mathrm{IT}, 1998 \mathrm{a})$ \\
\hline System Dynamics & $\begin{array}{l}\text { No driving forces other than infiltration of limited } \\
\text { precipitation. Groundwater contamination is unlikely } \\
\text { due to environmental conditions at the site, such as an } \\
\text { arid climate and depth to groundwater. }\end{array}$ & $\begin{array}{l}\text { Knowledge of Similar Sites } \\
\text { (DOE/NV, 1996a) }\end{array}$ \\
\hline Source Locations & $\begin{array}{l}\text { Batteries used as power supply for repeater equipment } \\
\text { and discarded on the surface near the repeater mast. }\end{array}$ & $(\mathrm{IT}, 1998 \mathrm{a})$ \\
\hline $\begin{array}{l}\text { Contaminants of Potential } \\
\text { Concern }\end{array}$ & None identified to date. & $\begin{array}{l}\text { Process knowledge } \\
(\mathrm{IT}, 1998 \mathrm{a})\end{array}$ \\
\hline $\begin{array}{l}\text { Lateral Extent of Potential } \\
\text { Contaminants }\end{array}$ & No potential contaminants identified to date. & $\begin{array}{l}\text { Process knowledge } \\
(\mathrm{IT}, 1998 \mathrm{a})\end{array}$ \\
\hline $\begin{array}{c}\text { Vertical Extent of } \\
\text { Potential Contaminants }\end{array}$ & No potential contaminants identified to date. & (IT, 1998a) \\
\hline $\begin{array}{l}\text { Physical and Practical } \\
\text { Constraints }\end{array}$ & $\begin{array}{l}\text { U.S. Air Force and/or Sandia range activities, adverse } \\
\text { weather conditions, restricted access, health and safety } \\
\text { concerns, and approval of the CAIP. }\end{array}$ & $\begin{array}{l}\text { Site knowledge and Site Visit } \\
\text { (IT, 1998a) }\end{array}$ \\
\hline Future Use & $\begin{array}{l}\text { The Final Environmental Impact Statement for the } \\
\text { Nevada Test Site and Off-Site Locations in the State of } \\
\text { Nevada states that future use will be similar to current } \\
\text { use. Current use only includes industrial and research } \\
\text { and development related activities at TTR. }\end{array}$ & $\begin{array}{l}\text { Assumptions are defined in } \\
\text { the Final Impact Statement } \\
\text { for the Nevada Test Site and } \\
\text { Off-Site Locations in the } \\
\text { State of Nevada } \\
\text { (DOE/NV, 1996b) }\end{array}$ \\
\hline Potential Exposures & None identified to date. & $\begin{array}{l}\text { Site knowledge and Site Visit } \\
\text { (IT, 1998a) }\end{array}$ \\
\hline Waste Management & No waste will be generated during this activity. & $\begin{array}{l}\text { Site knowledge and Site Visit } \\
(\mathrm{IT}, 1998 \mathrm{a})\end{array}$ \\
\hline
\end{tabular}




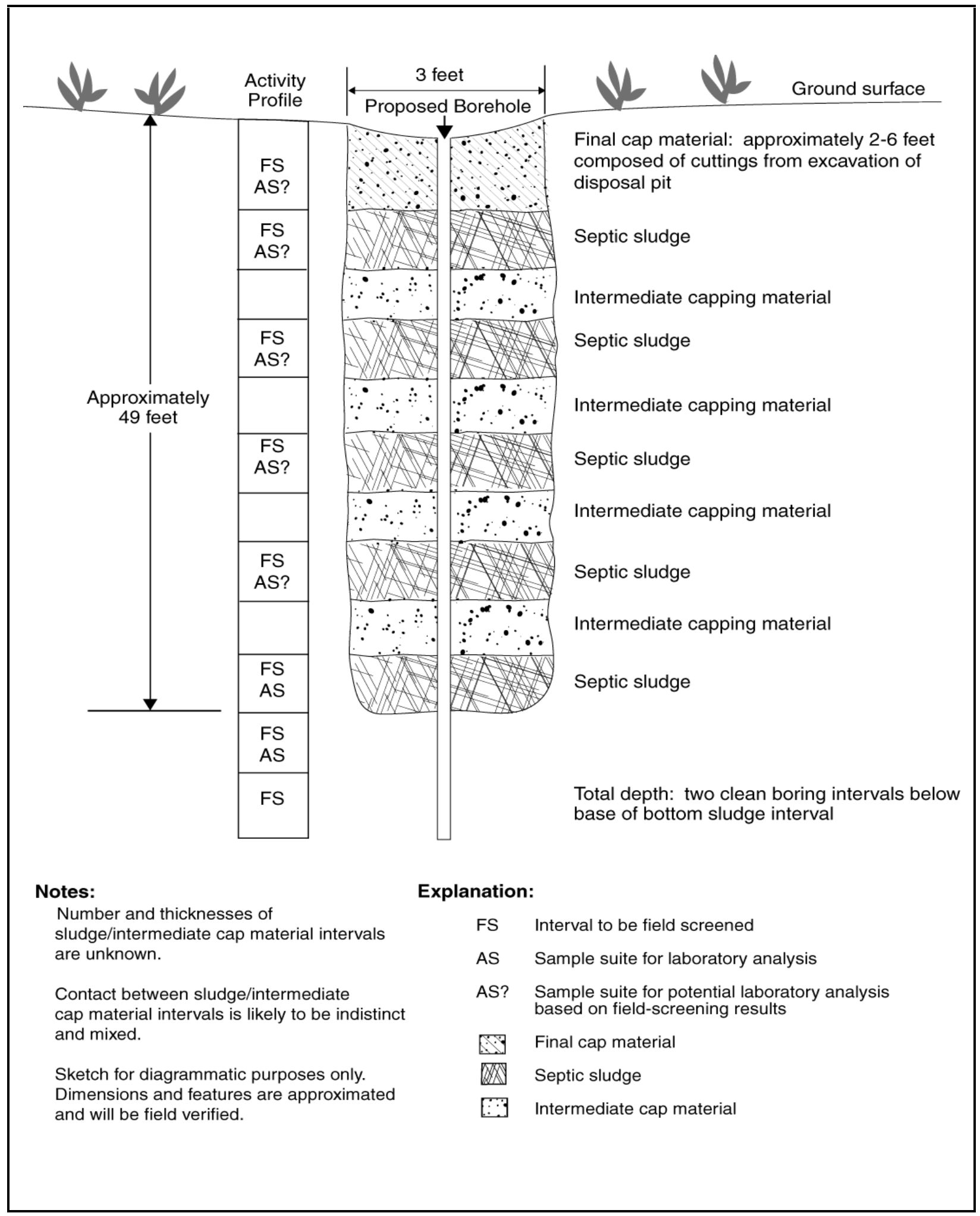

Figure A.2-1

Diagrammatic Sketch of Septic Sludge Disposal Pits Area 3, Tonopah Test Range 


\section{A.2.2.1 Contaminants of Potential Concern}

The COPCs are the same for both CAS TA-53-001-TAB2 and CAS TA-53-002-TAB2. Septic tank sludge from Septic Waste System (SWS) 1 and 5 disposed of in these two pits is assumed to contain COPCs similar to the sludge material sampled directly from the septic tanks. Previous septic tank sampling efforts (conducted at CAU 427 in 1991, 1993, 1998, and CAU 428 in 1999) and process knowledge identify the following potential contaminants for SWS 1 and 5:

- SWS 1 served several buildings in the northern portion of the Area 3 compound. This system was used from the construction of Building 03-50 until completion of the consolidated sewer system in 1990. Potentially contaminated sanitary effluent discharged to the system produced elevated levels of COPCs within the septic waste system. Septic tank sampling has identified VOCs, SVOCs, RCRA metals, petroleum hydrocarbons, phenolics, PCBs, and elevated radiological activities.

- SWS 5 may have received effluent contaminated with RCRA metals (especially silver) associated with the photo processing laboratory in Building 03-50. The system also received effluent from floor drains that may have been contaminated with constituents produced by janitorial activities or by operations within Building 03-50.

Based on the above information, the following COPCs will be considered for the Septic Sludge Disposal Pits: total VOCs, total SVOCs, total RCRA metals, total PCBs, TPH (GDRO), isotopic plutonium, and isotopic uranium. These constituents may have been produced by activities within buildings served by SWS 1 and 5. Phenolics will be detected by SVOC analyses. Cyanide is not considered a COPC as the concentrations in the three samples were well below the EPA PRGs and very near the laboratory detection limits. A summary of analytical results from previous sampling events is provided in Appendix D. Additional information on the COPCs for CAU 409, including PALs and QA/QC requirements, are provided in Section 3.0 of the CAIP.

Table A.2-2 lists the COPCs for the Septic Sludge Disposal Pits and their associated fieldscreening methods and levels as well as the PALs.

\section{A.2.2.2 Physical Setting}

Based on process knowledge and interviews of TTR workers, sludge was pumped out of the Area 3 septic tanks every few years and buried in augered holes that measured approximately $3 \mathrm{ft}$ in diameter and $49 \mathrm{ft}$ deep (Elliston, 2000). Approximately eight tanks ranging from 750- to 1,500-gallon capacity were pumped during these activities. 
Table A.2-2

COPCs for CAS TA-53-001-TAB2, Septic Sludge Disposal Pit \#1 and CAS TA-53-002-TAB2, Septic Sludge Disposal Pit \#2

\begin{tabular}{|c|c|c|c|c|c|}
\hline $\begin{array}{c}\text { Potential } \\
\text { Contaminants }\end{array}$ & $\begin{array}{l}\text { Field-Screening } \\
\text { Method }\end{array}$ & $\begin{array}{c}\text { Field-Screening } \\
\text { Level }\end{array}$ & $\begin{array}{l}\text { Preliminary } \\
\text { Action Level }\end{array}$ & Analytical Method & $\begin{array}{c}\text { Practical } \\
\text { Quantitation Limit } \\
\text { (soil/water) }\end{array}$ \\
\hline $\begin{array}{l}\text { Volatile Organic } \\
\text { Compounds }\end{array}$ & Headspace & $\begin{array}{c}20 \text { ppm or } 2.5 X \\
\text { background (use } \\
\text { greater value) }\end{array}$ & $\begin{array}{c}\text { PRGsa } \\
\text { NAC445A }^{b}\end{array}$ & \multirow{6}{*}{ See Appendix C } & \multirow{6}{*}{ See Appendix C } \\
\hline $\begin{array}{l}\text { Semivolatile } \\
\text { Organic } \\
\text { Compounds }\end{array}$ & NA & NA & $\begin{array}{c}\text { PRGs }^{\mathrm{a}} \\
\mathrm{NAC4}^{2} \mathrm{~A}^{\mathrm{b}}\end{array}$ & & \\
\hline $\begin{array}{l}\text { Total RCRA } \\
\text { Metals }\end{array}$ & NA & $\begin{array}{l}1,000 \text { ppm } \\
\text { (silver only) }\end{array}$ & $\begin{array}{c}\text { PRGs }{ }^{a} \\
\text { NAC445A }^{b}\end{array}$ & & \\
\hline PCBs & NA & NA & $\begin{array}{c}\text { PRGs }^{a} \\
\text { NAC445A }^{b}\end{array}$ & & \\
\hline $\begin{array}{l}\text { Total Petroleum } \\
\text { Hydrocarbons }\end{array}$ & $\begin{array}{l}\text { Ultraviolet } \\
\text { Fluorescence }\end{array}$ & 75 ppm & $\begin{array}{c}100 \mathrm{ppm} \\
\text { NAC445A }^{\mathrm{b}}\end{array}$ & & \\
\hline $\begin{array}{l}\text { Radionuclides } \\
\text { (plutonium and } \\
\text { uranium) }\end{array}$ & $\begin{array}{c}\text { Electra (alpha/ } \\
\text { beta scintillator) }\end{array}$ & $\begin{array}{l}\text { Mean plus } 2 \\
\text { standard } \\
\text { deviations of } 20 \\
\text { background } \\
\text { sample readings }\end{array}$ & $\begin{array}{l}\text { Isotope-specific } \\
\text { value based on } \\
\text { maximum } \\
\text { isotopic } \\
\text { background } \\
\text { data }\end{array}$ & & \\
\hline
\end{tabular}

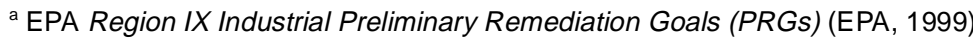

${ }^{\mathrm{b}}$ Nevada Administrative Code (NAC, 1999)

NA $=$ Not applicable

The following assumptions were used to evaluate the volume of material potentially disposed of in the two pits versus the volume of the disposal pits:

- Tanks pumped out when full

- An average tank volume of 1,000 gallons

- Tanks would only need pumping after 2 to 3 years of use

- When full, the tanks contained 10 percent scum, 40 percent liquid, and 50 percent sludge

- When sludge is dewatered after placement in the pits, approximately 10 percent of the original volume would remain

Based on these assumptions, a single pumping event would result in a total of 400 gallons of dewatered sludge material remaining in the pits. The two pits have a combined volume of 
approximately 5,280 gallons. This volume would accommodate backfill material used as a cap between pumping events and approximately 10 pumping and disposal events.

These pumping and disposal activities are believed to have continued until the late 1980s. Septic tank contents consisted of sanitary wastewater and small amounts of industrial wastewater containing Stoddard solvent, cutting oils, cleaning solutions, photo chemicals, medical/laboratory waste (based on a medical trailer identified as a source building for one of the Area 3 septic waste systems), and paint solvents. Unknown volumes and concentrations of these materials and other chemicals may have been released in surface and subsurface soils at the two Septic Sludge Disposal Pits. No radiological waste was documented as being disposed of in Area 3 septic waste systems.

Based on the limited history discussed in the preceding paragraphs, it is believed the two Septic Sludge Disposal Pits contain alternating layers of septic sludge material and backfill material (composed of cuttings generated when the disposal pits were initially augered). These layers most likely range in thickness of 1 to $4 \mathrm{ft}$ each. The upper 4 to $6 \mathrm{ft}$ of the disposal pits is most likely cuttings or clean backfill material used as a final capping material.

An outline of site-specific elements of the conceptual model for the Septic Sludge Disposal Pits is provided in Table A.2-3. Section 2.0 of the CAIP describes the operational histories, waste inventories, release information, and investigative background for each of the CASs. 
Table A.2-3

Conceptual Model for CAS TA-53-001-TAB2, Septic Sludge Disposal Pit \#1 and CAS TA-53-002-TAB2, Septic Sludge Disposal Pit \#2

(Page 1 of 2)

\begin{tabular}{|c|c|c|}
\hline $\begin{array}{l}\text { Conceptual Model } \\
\text { Element }\end{array}$ & Assumptions & Source \\
\hline \multirow[t]{2}{*}{ Physical Setting } & $\begin{array}{l}\text { The location of Pit \#1 is approximately } 680 \mathrm{ft} \text { east of } \\
\text { RB-35 gate near Bunker } 2 \text {; Pit \#2 is located } \\
\text { approximately } 75 \mathrm{ft} \text { north of Pit \#1(aerial photo). The } \\
\text { location of the pits appear as round depressions } \\
\text { approximately } 3 \mathrm{ft} \text { in diameter and } 2 \text { in. deep near a } \\
\text { sparsely vegetated (disturbed area) tract measuring } \\
\text { approximately } 110 \mathrm{ft} \times 120 \mathrm{ft} \text {. }\end{array}$ & $\begin{array}{l}\text { (Aerial photograph, RSL } \\
9997-283 / 14 / 99) \\
(I T, 1998 b) \\
\text { (DOE/NV, 1994) }\end{array}$ \\
\hline & $\begin{array}{l}\text { Currently no evidence of staining of soil on surface. } \\
\text { Geophysical surveys (ground penetrating radar and } \\
\text { electromagnetic survey) conducted specifically for these } \\
\text { CASs were inconclusive with respect to defining the } \\
\text { extent of the pits. }\end{array}$ & (IT, 1997) \\
\hline \multirow[b]{2}{*}{ System Dynamics } & $\begin{array}{l}\text { No driving forces other than infiltration of limited } \\
\text { precipitation. }\end{array}$ & $\begin{array}{l}\text { Knowledge of similar sites, } \\
\text { CAU Work Plan } \\
\text { (DOE/NV, 1996a) }\end{array}$ \\
\hline & $\begin{array}{l}\text { Groundwater contamination is unlikely due to } \\
\text { environmental conditions at the site, such as an arid } \\
\text { climate, low permeabilities, and depth to groundwater } \\
\text { greater than } 360 \mathrm{ft} \text {. }\end{array}$ & (DOE/NV, 1996a) \\
\hline \multirow[t]{2}{*}{ Source Locations } & $\begin{array}{l}\text { Sludge pumped from various Area } 3 \text { septic tanks. SWS } 1 \\
\text { received effluent from several buildings in the northern } \\
\text { portion of the Area } 3 \text { compound. Source buildings for } \\
\text { SWS } 1 \text { include: } 03-50 \text {, Medical Trailer, 03-73, 03-75, } \\
\text { 03-63, 03-76, various buildings on the northwest corner } \\
\text { of the Area } 3 \text { compound, and the former DoD buildings } \\
\text { and trailers north of the Area } 3 \text { compound. }\end{array}$ & $\begin{array}{l}\text { Archival engineering } \\
\text { drawings and site visits } \\
\text { (SNL, 1992) }\end{array}$ \\
\hline & $\begin{array}{l}\text { Septic Waste System } 5 \text { (SWS 5) received effluent from a } \\
\text { former photo processing laboratory and floor drains in } \\
\text { Building } 03-50 .\end{array}$ & $\begin{array}{l}\text { Archival engineering } \\
\text { drawings and site visits } \\
\text { (SNL, 1992) }\end{array}$ \\
\hline \multirow{2}{*}{$\begin{array}{l}\text { Contaminants of } \\
\text { Potential Concern }\end{array}$} & $\begin{array}{l}\text { VOCs, SVOCs, RCRA metals, petroleum hydrocarbons, } \\
\text { phenolics, PCBs, and elevated radiological activities } \\
\text { detected by previous sampling of several SWS } 1 \text { septic } \\
\text { tanks. }\end{array}$ & $\begin{array}{l}\text { Septic tank sampling efforts } \\
(\text { IT, } 1991 \text { and 1994) }\end{array}$ \\
\hline & $\begin{array}{l}\text { Concentrations of COPCs determined for disposal of } \\
\text { SWS } 1 \text { septic tank contents in a public-owned treatment } \\
\text { works. Analysis based on Clean Water Act Maximum } \\
\text { Contaminant Levels. }\end{array}$ & $\begin{array}{l}\text { Septic tank sampling efforts } \\
\text { (IT, } 1991 \text { and 1994) }\end{array}$ \\
\hline
\end{tabular}


Table A.2-3

Conceptual Model for CAS TA-53-001-TAB2, Septic Sludge Disposal Pit \#1 and CAS TA-53-002-TAB2, Septic Sludge Disposal Pit \#2

(Page 2 of 2 )

\begin{tabular}{|c|c|c|}
\hline $\begin{array}{l}\text { Conceptual Model } \\
\text { Element }\end{array}$ & Assumptions & Source \\
\hline \multirow[t]{2}{*}{$\begin{array}{l}\text { Lateral Extent of } \\
\text { Potential Contaminants }\end{array}$} & $\begin{array}{l}\text { Lateral extent of potential contamination is unknown; } \\
\text { however, subsurface effects are limited by relatively low } \\
\text { contaminant concentrations and low volume (based on } \\
\text { Septic Tank Sampling) and/or low mobility of constituents } \\
\text { due to the lack of a hydraulic driving force. }\end{array}$ & $\begin{array}{l}\text { Process knowledge, and } \\
\text { CAU } 428 \text { CADD }\end{array}$ \\
\hline & $\begin{array}{l}\text { The radius of lateral contamination is not expected to } \\
\text { extend beyond } 10 \mathrm{ft} \text { from the outer edge of the borehole } \\
\text { the septic sludge was placed in. }\end{array}$ & Process knowledge \\
\hline \multirow[t]{2}{*}{$\begin{array}{l}\text { Vertical Extent of } \\
\text { Potential Contaminants }\end{array}$} & $\begin{array}{l}\text { The vertical extent of potential contamination is unknown. } \\
\text { Vertical extent should be limited by low contaminant } \\
\text { concentrations and low volumes, minimal driving forces, } \\
\text { relatively low mobility of COPCs and very low vertical } \\
\text { permeability of the evaporite rocks found at the sludge } \\
\text { rock interface at the bottom of the boring. }\end{array}$ & Process knowledge \\
\hline & $\begin{array}{l}\text { Vertical extent of potential contamination is not expected } \\
\text { to extend beyond a depth of } 53 \mathrm{ft} \text { bgs. }\end{array}$ & $\begin{array}{l}\text { Ecology and Environment, } \\
\text { Inc. } 1989, \text { and SNL, } 1992 .\end{array}$ \\
\hline $\begin{array}{l}\text { Physical and Practical } \\
\text { Constraints }\end{array}$ & $\begin{array}{l}\text { U.S. Air Force and/or Sandia range activities; } \\
\text { underground/aboveground utilities; adverse weather } \\
\text { conditions; restricted access; heavy equipment and } \\
\text { resource availability; health and safety concerns; } \\
\text { approval of the CAIP. }\end{array}$ & $\begin{array}{l}\text { Site knowledge, Site Visits } \\
\text { (IT, 1998b) }\end{array}$ \\
\hline Future Use & $\begin{array}{l}\text { The Final Environmental Impact Statement for the } \\
\text { Nevada Test Site and Off-Site Locations in the State of } \\
\text { Nevada states that future use will be similar to current } \\
\text { use. Current use only includes industrial and research } \\
\text { and development related activities in Area } 3 \text { and Area } 9 .\end{array}$ & $\begin{array}{l}\text { Assumptions are defined in } \\
\text { the Final Impact Statement } \\
\text { for the Nevada Test Site and } \\
\text { Off-Site Locations in the } \\
\text { State of Nevada } \\
\text { (DOE/NV, 1996b) }\end{array}$ \\
\hline Potential Exposures & $\begin{array}{l}\text { Ingestion, inhalation, or dermal contact (absorption) of } \\
\text { COPCs in the soil due to inadvertent exposure during } \\
\text { investigation. }\end{array}$ & Process knowledge \\
\hline Waste Management & $\begin{array}{l}\text { No evidence of listed waste has been found; waste will } \\
\text { be considered characteristic unless contradictory } \\
\text { information is discovered during the investigation. }\end{array}$ & Process knowledge \\
\hline
\end{tabular}




\section{A.3.0 Decisions and Inputs}

\section{A.3.1 Decisions}

Decisions to be resolved by the activities and investigations at the CASs include:

- Determine if COPCs are present at the sites.

- Determine if COPC concentrations exceed FSLs.

- Determine if COPC concentrations exceed PALs.

- Determine the nature and extent of contamination with enough certainty to develop and evaluate a range of potential corrective actions, including closure in place and clean closure.

\section{A.3.2 Inputs and Strategy}

Inputs to the decisions include those elements of information used to support the decisions in addressing the problems stated in Section A.1.1.

\section{Battery Dump Site}

The Battery Dump Site will be addressed under the Sectored Clean-up Work Plan and no contamination is expected to be encountered. Input and strategy is to locate all the batteries and other materials related to the repeater, and photograph the items before and after removal to document the clean-up.

\section{Septic Sludge Disposal Pits}

A list of information inputs, existing data, identified data gaps, and brief strategies are discussed in Table A.3-1. 
Table A.3-1

Decisions, Inputs, and General Strategies

(Page 1 of 3 )

\begin{tabular}{|c|c|c|c|c|}
\hline Decision & Input & Existing Data & Data Gap & Strategy \\
\hline \multirow{3}{*}{$\begin{array}{l}\text { Are COPCs present } \\
\text { above PALs at site? }\end{array}$} & $\begin{array}{l}\text { Potential contaminant } \\
\text { identification }\end{array}$ & $\begin{array}{l}\text { Septic tank sampling efforts } \\
(I T, 1991 \text { and 1994) }\end{array}$ & Exact/complete list of COPCs & $\begin{array}{l}\text { Collect laboratory samples; } \\
\text { analyze for COPCs based on } \\
\text { CAU } 427 \text { and } 428 \text { sampling } \\
\text { results }\end{array}$ \\
\hline & $\begin{array}{l}\text { Potential contaminant } \\
\text { concentration }\end{array}$ & $\begin{array}{l}\text { Septic tank sampling efforts } \\
\text { (IT, } 1991 \text { and 1994) }\end{array}$ & $\begin{array}{l}\text { COPC concentrations } \\
\text { produced by SW } 846 \\
\text { methods. Do concentrations } \\
\text { exceed PALs? }\end{array}$ & $\begin{array}{l}\text { Collect samples from soil; } \\
\text { perform field screening and } \\
\text { compare results to FSLs; } \\
\text { submit samples for laboratory } \\
\text { analysis from biased locations } \\
\text { that represent worst case for } \\
\text { contamination and } \\
\text { confirmatory clean locations; } \\
\text { compare results to PALs }\end{array}$ \\
\hline & $\begin{array}{l}\text { Potential contaminant } \\
\text { distribution }\end{array}$ & $\begin{array}{l}\text { Approximate boundaries of } \\
\text { disposal pit sites are known; } \\
\text { vertical and lateral extent } \\
\text { limited by minimal driving } \\
\text { forces, low volumes, and } \\
\text { concentrations }\end{array}$ & $\begin{array}{l}\text { Vertical and lateral extent of } \\
\text { COPCs }\end{array}$ & $\begin{array}{l}\text { Use drilling to establish } \\
\text { potential depth of COPCs; } \\
\text { conduct step-outs as required } \\
\text { to determine lateral extent if } \\
\text { COPCs are detected; collect } \\
\text { laboratory samples to confirm } \\
\text { extent }\end{array}$ \\
\hline
\end{tabular}


Table A.3-1

Decisions, Inputs, and General Strategies

(Page 2 of 3)

\begin{tabular}{|c|c|c|c|c|}
\hline Decision & Input & Existing Data & Data Gap & Strategy \\
\hline \multirow{4}{*}{$\begin{array}{l}\text { Are potential } \\
\text { contaminants } \\
\text { migrating? }\end{array}$} & Meteorologic data & $\begin{array}{l}\text { Data on annual precipitation, } \\
\text { evapotranspiration, and } \\
\text { weather }\end{array}$ & None identified & $\begin{array}{l}\text { No specific meteorological } \\
\text { data collection anticipated; } \\
\text { general weather and wind } \\
\text { speed and direction noted on } \\
\text { daily field logs }\end{array}$ \\
\hline & Geologic/hydrologic data & $\begin{array}{l}\text { General geologic/hydrologic } \\
\text { characteristics of site; specific } \\
\text { geologic conditions of nearby } \\
\text { sites (i.e., CAU 428); } \\
\text { background concentrations for } \\
\text { arsenic typically higher than } \\
\text { PALs }\end{array}$ & $\begin{array}{l}\text { Existence and characteristics } \\
\text { of differing permeability zones }\end{array}$ & $\begin{array}{l}\text { Field log all core by qualified } \\
\text { geologist; collect and analyze } \\
\text { geotechnical samples at } \\
\text { discretion of Site Supervisor } \\
\text { (native soil below septic } \\
\text { sludge is critical) }\end{array}$ \\
\hline & Biological degradation factors & $\begin{array}{l}\text { Potential hydrocarbon } \\
\text { release; biologic conditions of } \\
\text { nearby sites (i.e., CAU 428) }\end{array}$ & $\begin{array}{l}\text { Presence of Biomass; } \\
\text { biological parameters to } \\
\text { evaluate natural biological } \\
\text { process }\end{array}$ & $\begin{array}{l}\text { May collect bioassessment } \\
\text { samples from samples based } \\
\text { on field-screening results }\end{array}$ \\
\hline & Radioactive decay & $\begin{array}{l}1991 \text { and } 1993 \text { Septic tank } \\
\text { sampling effort identified } U^{238} \text {, } \\
U^{234} \text {, and elevated gross alpha } \\
\text { and gross beta counts for } \\
\text { some samples. Only gross } \\
\text { beta particle activity slightly } \\
\text { above proposed Safe Drinking } \\
\text { Water Act, Maximum } \\
\text { Contaminant Level threshold } \\
\text { value in Septic Tank 33-10; } \\
\text { confirmed by } 1993 \\
\text { resampling. Sampling results } \\
\text { are discussed in Section A.2.2 } \\
\text { and provided in Appendix D. }\end{array}$ & $\begin{array}{l}\text { Presence and type of } \\
\text { radionuclides }\end{array}$ & $\begin{array}{l}\text { Establish background; field } \\
\text { screen for alpha/beta-emitting } \\
\text { radionuclides using an alpha/ } \\
\text { beta scintillation detector } \\
\text { (i.e., Electra); collect limited } \\
\text { samples for gamma } \\
\text { spectroscopy, isotopic } \\
\text { uranium, and isotopic } \\
\text { plutonium analysis depending } \\
\text { on field-screening results }\end{array}$ \\
\hline
\end{tabular}


Table A.3-1

Decisions, Inputs, and General Strategies

(Page 3 of 3 )

\begin{tabular}{|c|c|c|c|c|}
\hline Decision & Input & Existing Data & Data Gap & Strategy \\
\hline \multirow{4}{*}{$\begin{array}{l}\text { Data sufficient to } \\
\text { support closure } \\
\text { options? }\end{array}$} & No further action & $\begin{array}{l}\text { Historical evidence that } \\
\text { COPCs were released to the } \\
\text { environment; assume no } \\
\text { actions }\end{array}$ & $\begin{array}{l}\text { Presence, concentration, and } \\
\text { extent of COPCs }\end{array}$ & $\begin{array}{l}\text { Insufficient evidence to } \\
\text { proceed without investigation; } \\
\text { collect field and laboratory } \\
\text { samples; compare analytical } \\
\text { results to PALs; if no COPCs } \\
\text { above PALs, prepare CADD/ } \\
\text { Closure Report }\end{array}$ \\
\hline & Closure in place & $\begin{array}{l}\text { Potential for RCRA and TPH } \\
\text { constituents; assume } \\
\text { industrial PRGs and } 100 \text { ppm } \\
\text { TPH per NAC 445A } \\
\text { (NAC, 1999); assume use } \\
\text { restrictions }\end{array}$ & $\begin{array}{l}\text { Presence of regulated } \\
\text { COPCs; concentrations above } \\
\text { PALs; septic tank sampling } \\
\text { efforts (IT, } 1991 \text { and 1994) }\end{array}$ & $\begin{array}{l}\text { Collect field and laboratory } \\
\text { samples; compare analytical } \\
\text { results to PALs; if TPH above } \\
\text { PAL, prepare A through K } \\
\text { evaluation per NAC } 445 A \text {; if } \\
\text { no COPCs above PALs, } \\
\text { prepare CADD/CR; otherwise } \\
\text { prepare CADD }\end{array}$ \\
\hline & In situ bioremediation & $\begin{array}{l}\text { Oil and grease detected } \\
\text { above PALs by septic tank } \\
\text { sampling; assume } 100 \mathrm{ppm} \\
\text { PAL per NAC } 445 \mathrm{~A} \\
\text { (NAC, 1999) }\end{array}$ & $\begin{array}{l}\text { Presence, concentration, and } \\
\text { extent of COPCs; } \\
\text { biodegradation parameters }\end{array}$ & $\begin{array}{l}\text { Collect field and laboratory } \\
\text { samples; compare analytical } \\
\text { results to PALs; if no COPCs } \\
\text { above PALs, prepare } \\
\text { CADD/CR; otherwise prepare } \\
\text { CADD }\end{array}$ \\
\hline & $\begin{array}{l}\text { Clean closure by contaminant } \\
\text { removal }\end{array}$ & $\begin{array}{l}\text { Potential for RCRA and TPH } \\
\text { constituents; assume } \\
\text { industrial PRGs and } 100 \text { ppm } \\
\text { TPH per NAC 445A } \\
\text { (NAC, 1999) }\end{array}$ & $\begin{array}{l}\text { Presence, concentration, and } \\
\text { extent of COPCs; volume of } \\
\text { contaminated material above } \\
\text { PALs }\end{array}$ & $\begin{array}{l}\text { Collect field and laboratory } \\
\text { samples; compare analytical } \\
\text { results to PALs; if no COPCs } \\
\text { above PALs, prepare } \\
\text { CADD/CR; otherwise prepare } \\
\text { CADD }\end{array}$ \\
\hline
\end{tabular}




\section{A.4.0 Field Activity/Investigation Strategy}

The following sections will discuss the activities/investigations to be conducted at each of the CASs in CAU 409. Those activities considered most likely to occur will be discussed as the Primary Investigation Plan. If circumstances or conditions arise that prevent the Primary Investigation Plan from being executed, but not significant enough to require rescoping of the effort, the Contingency Plan will be implemented. Both plans will be discussed for the Battery Dump Site as well as the Septic Sludge Disposal Pits.

\section{A.4.1 Battery Dump Site Primary Investigation Plan}

The field activities anticipated to occur at the Battery Dump Site include collecting the batteries and other debris located at the site and documenting the clean-up by photographing the site.

\section{A.4.2 Battery Dump Site Contingency Plan}

If soil staining is identified during the clean-up activities, biased soil sampling will be conducted. The surface soil samples will be excavated with hand tools and submitted for laboratory analysis of total RCRA metals to confirm the presence of contamination.

Laboratory confirmation of contamination present at the site will result in rescoping of the Battery Dump Site to include activities to adequately characterize the site and provide the information necessary to select a corrective action.

\section{A.4.3 Septic Sludge Disposal Pits Primary Investigation Plan}

Investigation activities to be conducted at the disposal pits include drilling, and selecting samples for field screening and laboratory analysis. The basis for selecting the samples will be a biased sampling strategy.

\section{A.4.3.1 Biased Sampling Strategy}

Due to the dimensions of the two Septic Sludge Disposal Pits, a small surface expression of approximately $3 \mathrm{ft}$ in diameter and $50 \mathrm{ft}$ deep, COPCs do not exist in a "Normal Distribution" setting. Therefore, biased sampling will be conducted at the two Septic Sludge Disposal Pits. A biased sampling strategy is intended to target the worst-case contamination by sampling locations 
with the highest potential for contamination. It is anticipated that the areas of highest potential contamination will be encountered by drilling and collecting biased samples through the center of the disposal pits. The COPCs in the pits will be identified and representative concentrations determined. The lateral extent of the COPCs, if present, will be determined by the installation of step-out borings.

The biased sampling will assess the extent of COPCs and determine if COPC concentrations exceed PALs for the sites. Samples collected from the CASs will be analyzed for COPCs listed in Table A.2-2. This will ensure that the vertical extent of possible contamination has been adequately characterized. Planned sample intervals may be substituted at the Site Supervisor's discretion with intervals that indicate highest contamination for that sample location as determined by visual and/or other field-screening techniques. At least one sample with FSRs below FSLs will be obtained from the predetermined sampling locations to define the lower limit of the contamination (if any) on soils. Field-screening results will be confirmed by off-site laboratory analysis for these samples. This sampling strategy will ensure that contamination in the soil has been adequately located, identified, and quantified.

\section{A.4.3.2 Sampling Locations}

Samples will be collected at CAU 409 using rotosonic, hollow-stem auger, or other drilling methods. The borings will be extended to a minimum of $60 \mathrm{ft}$ bgs and will be advanced until FSRs are below FSLs for two consecutive boring intervals. Sample locations within the borehole are discussed in the following sections.

To determine background radiological values, a boring will be drilled to $60 \mathrm{ft}$ bgs, prior to drilling the borehole in Disposal Pit \#1, at a location where similar stratigraphic and geologic characteristics are expected. Downhole radiation measurement will be performed in the borehole. Alpha and beta count rates will be logged at 3-ft intervals (for a total of 20 data points) to provide a vertical profile of background radiological activity in the subsurface soils. These data will be used to establish FSLs for radioactivity by calculating the mean background activity and adding two standard deviations. Samples will be collected in this boring from the three intervals with the highest activity and submitted for laboratory analysis as a quality control check. 


\section{Field-Screening Sample Locations}

Samples for field screening will be collected from the upper capping material and each layer of septic sludge in the disposal pit, and/or at locations of obvious staining or contamination. All soil samples will be field screened for VOCs, TPH, silver, and alpha/beta-emitting radionuclides (except those that may be collected at the Battery Dump Site, as described in Section A.4.2). The headspace method with a PID will be used for VOCs. Ultraviolet fluorescence will be used for $\mathrm{TPH}, \mathrm{X}$-ray fluorescence will be used for silver, and an alpha/beta scintillator will be used to detect radioactivity.

\section{Sample Locations for Laboratory Analysis}

A minimum of three samples from each disposal pit will be submitted for laboratory analysis of COPCs identified in Table A.2-2. The sample from the basal sludge unit, from an interval directly below the fill/native soil interface, and the first of two samples where FSRs are less than FSLs will be submitted. Additional samples for laboratory analysis may be submitted based on FSRs and visual observations. All samples with FSRs above FSLs will be documented in the field $\log$ and boring log. Sampling location criteria are discussed in Table A.4-1.

Geotechnical and bioassessment samples may be collected at the Site Supervisor's discretion. Bioassessment samples will be collected if FSRs for VOCs or TPH significantly exceed FSLs. Geotechnical samples will be analyzed using the methods in Table 3-2 of the Leachfield Work Plan to measure the following parameters:

- Initial moisture content

- Dry bulk density

- Calculated porosity

- Moisture retention characteristics

- Particle size distribution

- Saturated and unsaturated hydraulic conductivity

\section{Step-Out Boring Sampling Locations}

Step-out borings will be located in a triangular pattern ( $5 \mathrm{ft}$ and $10 \mathrm{ft}$ from edge of pit) around the disposal pits, if FSLs are exceeded at any interval in the initial borehole. The first step-out boring will be drilled at a 5-ft center from the edge of the pit. Based on FSRs, additional step-outs may 
Table A.4-1

Sample Collection Locations for Laboratory Analysis

\begin{tabular}{|c|c|c|}
\hline $\begin{array}{l}\text { Interval } \\
\text { Feet (ft) }\end{array}$ & Material Description & Criteria \\
\hline 0 to $4 \mathrm{ft}$ & $\begin{array}{l}\text { This should be the final capping material } \\
\text { (est. of } 4 \text { to } 6 \mathrm{ft} \text { thick). }\end{array}$ & $\begin{array}{l}\text { Determine thickness of capping material and collect sample where } \\
\text { staining may exist or FSLs are exceeded. If these conditions are not } \\
\text { present, collect a representative sample. Location will be at the Site } \\
\text { Supervisor's discretion. }\end{array}$ \\
\hline 4 to $10 \mathrm{ft}$ & $\begin{array}{l}\text { Expect this material to be septic sludge } \\
\text { material (fairly soft and retaining some } \\
\text { characteristics of septic sludge } \\
\text { [i.e., medium brown color]). }\end{array}$ & $\begin{array}{l}\text { Determine thickness of septic sludge material by identifying the } \\
\text { intermediate capping material below the sludge. Collect sample } \\
\text { where staining may exist or FSLs are exceeded. If these conditions } \\
\text { are not present, collect a representative sample. Location will be at } \\
\text { the Site Supervisor's discretion. }\end{array}$ \\
\hline 10 to $13 \mathrm{ft}$ & $\begin{array}{l}\text { Expect this material to be intermediate } \\
\text { capping material (most likely clean fill or } \\
\text { cuttings). }\end{array}$ & $\begin{array}{l}\text { Determine thickness of intermediate capping material and collect } \\
\text { sample where staining may exist or FSLs are exceeded. If these } \\
\text { conditions are not present, collect a sample from the upper six } \\
\text { inches of the capping material. Based on actual field conditions, the } \\
\text { location may be changed at the Site Supervisor's discretion. }\end{array}$ \\
\hline 14 to $49 \mathrm{ft}$ & $\begin{array}{l}\text { Expect alternating layers of septic sludge } \\
\text { material and intermediate capping } \\
\text { material. }\end{array}$ & $\begin{array}{l}\text { For each layer of sludge material, use the criteria discussed above } \\
\text { for the } 4 \text { - to } 10 \text {-ft interval. }\end{array}$ \\
\hline 50 to $60 \mathrm{ft}$ & $\begin{array}{l}\text { The bottom of the pit is expected at } 49 \mathrm{ft} \text {. } \\
\text { Undisturbed native material should be } \\
\text { encountered. }\end{array}$ & $\begin{array}{l}\text { Collect a sample at } 1 \mathrm{ft} \text { into the undisturbed material. Collect } \\
\text { additional samples every } 2 \text { or } 5 \mathrm{ft} \text { (at discretion of the Site } \\
\text { Supervisor), or at any obvious staining or if FSLs are exceeded. } \\
\text { Sampling may cease if two consecutive samples do not exceed } \\
\text { FSLs. }\end{array}$ \\
\hline
\end{tabular}

be needed to delineate contaminant plume geometry. Step-out drilling will continue at intervals of $10 \mathrm{ft}$ until no contamination is encountered. Field screening will be conducted at intervals correlative to those intervals in the disposal pits where FSLs were exceeded and/or locations of obvious staining or contamination. Borings will be drilled to a depth sufficient to evaluate the deepest interval in the disposal pit where FSLs were exceeded. Drilling depths may exceed $60 \mathrm{ft}$ bgs at the Site Supervisor's discretion.

At least one sample from each of the step-out boreholes will be submitted to the laboratory for analysis. The sample(s) will be selected from the interval(s) that correlate with contamination detected in the borehole (based on FSRs) that initiated the advancement of that step-out boring. 


\section{A.4.4 Septic Sludge Disposal Pits Contingency Plan}

In the event soil sampling locations cannot be determined as specified in the Primary Investigation Plan, sampling locations will be selected based on this Contingency Plan. For example, if the cored soil material appears to be uniform color from the surface to $50 \mathrm{ft}$ bgs, the locations for field screening will be determined as stated in the following paragraphs.

\section{A.4.4.1 Field-Screening Locations}

If the layers of septic sludge material cannot be distinguished, samples for field screening will be collected at 10-ft intervals and/or at locations of obvious staining.

\section{A.4.4.2 Sample Locations for Laboratory Analysis}

A minimum of three samples will be submitted for laboratory analysis. The sample directly below the fill/native soil interface (if identified), the sample with the highest FSR, and the first of two consecutive samples where FSRs are below FSLs will be submitted. If the fill/native soil interface is not identified, this sample will be replaced with another sample at the discretion of the Site Supervisor. The Site Supervisor may submit additional samples for analysis, based on FSRs and visual observations. If step-out borings are required in this Contingency Plan, drilling and sampling decision points will be similar to those discussed in Section A.4.3.2. Samples that exceed FSLs and are submitted to the laboratory for analysis will be documented in the field log and boring log. Sampling location criteria are discussed in Table A.4-1.

\section{A.4.5 Special Laboratory Requirements}

As a precaution, the off-site laboratory used to analyze the soil samples will be required to generate and hold a leachate from samples to be used for a potential VOC and/or SVOC TCLP analysis. A metals TCLP analysis may also be requested. A TCLP analysis may be needed to characterize and dispose of IDW generated at the Septic Sludge Disposal Pits. 


\section{A.5.0 Decision Rules}

The following decision rules will be used to guide the investigation and subsequent data evaluation for CAU 409:

- If in the course of the investigation either of the following occur, the investigation will be halted and rescoped as necessary:

- The conceptual model fails to such a degree that rescoping is required.

- Sufficient data are collected to support evaluation of corrective actions.

- At each prescribed subsurface location, if field screening indicates no COPCs above FSLs, a sample at the next prescribed subsurface location will be field screened.

- If field screening indicates the presence of COPCs above FSLs, the investigation will continue to determine the vertical and lateral extent of COPCs. Disposal pit sampling will continue until two consecutive soil samples with contaminant concentrations below appropriate FSLs are obtained; whereupon, a sample will be submitted for laboratory analysis to verify field-screening results. Samples will also be submitted for laboratory analysis from the subsurface interval that represents the worst-case based on FSRs or at the discretion of the Site Supervisor. Additional samples may be required for waste management purposes.

- If laboratory results indicate the presence of contaminants of concern above PALs, a CADD will be prepared.

- If no COPCs are identified above PALs, a CADD/Closure Report will be prepared according to the outline agreed upon by NDEP and DOE/NV. This document incorporates the elements of the CADD and the corrective action plan and serves as the closure report for the site.

Table A.5-1 provides additional decision points and rules. 
Table A.5-1

\section{Activity-Specific Decision Points and Rules}

\begin{tabular}{|c|c|c|c|}
\hline $\begin{array}{l}\text { Investigation } \\
\text { Activity }\end{array}$ & Decision Point & $\begin{array}{l}\text { Decision } \\
\text { Result }\end{array}$ & Decision Rule \\
\hline \multirow{4}{*}{ Drilling } & \multirow{2}{*}{$\begin{array}{l}\text { Can an interface be } \\
\text { determined (identified by } \\
\text { fill/native soil)? }\end{array}$} & Yes & $\begin{array}{l}\text { Collect samples from required locations based on FSRs. Field screen the } 1 \text {-ft depth } \\
\text { intervals above and below the interface; submit the interval with highest FSR. }\end{array}$ \\
\hline & & No & $\begin{array}{l}\text { Continue drilling and collecting samples below the } 51 \text {-ft interval until the sludge and } \\
\text { native soil interface is identified. }\end{array}$ \\
\hline & \multirow{2}{*}{$\begin{array}{l}\text { Do COPCs extend } \\
\text { vertically beyond extent of } \\
\text { drilling rig capabilities? }\end{array}$} & Yes & $\begin{array}{l}\text { Collect and submit deepest sample with elevated FSRs within the boring, then initiate an } \\
\text { appropriate drilling method. }\end{array}$ \\
\hline & & No & Submit sample from upper interval with FSRs below FSLs. \\
\hline \multirow{8}{*}{ Sampling } & \multirow{2}{*}{$\begin{array}{l}\text { Can samples be } \\
\text { recovered from/around } \\
\text { Septic Sludge Disposal } \\
\text { Pit? }\end{array}$} & Yes & Continue subsurface investigation with drilling. \\
\hline & & No & $\begin{array}{l}\text { Samples that cannot be collected will be replaced or eliminated at the Site Supervisor's } \\
\text { discretion. Justification for such omissions will be provided to the DOE/NV Task } \\
\text { Manager and presented in the CADD. }\end{array}$ \\
\hline & \multirow{2}{*}{$\begin{array}{l}\text { Can sludge material be } \\
\text { differentiated from the } \\
\text { capping/fill material? }\end{array}$} & Yes & $\begin{array}{l}\text { Continue subsurface investigation with drilling and sample collection, as stated in } \\
\text { Section A.4.3.1. }\end{array}$ \\
\hline & & No & Collect samples from the cored material as defined in Section A.4.4 (contingency plan). \\
\hline & \multirow{2}{*}{$\begin{array}{l}\text { Are field data above } \\
\text { FSLs? }\end{array}$} & Yes & $\begin{array}{l}\text { Submit samples with highest FSRs for laboratory analysis. Collect additional samples } \\
\text { from greater depths or using step-outs, as required. }\end{array}$ \\
\hline & & No & Submit samples to laboratory for confirmation, as required. \\
\hline & \multirow{2}{*}{$\begin{array}{l}\text { Do COPCs exceed } \\
\text { PALs? }\end{array}$} & Yes & Prepare CADD. Additional sampling may be required. \\
\hline & & No & Prepare CADD/Closure Report. \\
\hline
\end{tabular}




\section{A.6.0 Decision Error}

\section{A.6.1 Primary Investigation Plan}

As discussed in Section A.4.3.1, biased sampling will be conducted at the two Septic Sludge Disposal Pits as opposed to conducting random sampling. Random sampling is appropriate where COPCs are expected to occur in a normal distribution across the area to be investigated. The COPCs in the disposal pits do not exist under a normal distribution and all layers of septic sludge that may contain COPCs can be sampled from a single borehole drilled through the center of the disposal pits ( $3 \mathrm{ft}$ in diameter). Therefore, since biased sampling will be conducted instead of random sampling, confidence levels cannot be calculated for the sampling of the disposal pits.

This sampling strategy targets the worst-case contamination by sampling through the center of the disposal pits, which represents an area with the highest potential for contamination and will ensure that the extent of the contamination has been adequately located and identified. Two consecutive samples below FSLs will be obtained from the predetermined sampling locations to define the lower limit of the affected soils. Field-screening results will be confirmed by off-site laboratory analysis of these samples.

\section{A.6.2 Contingency Plan}

If the cored (recovered) material from the Septic Sludge Disposal Pits is of uniform color and texture and cannot be differentiated for biased sampling, a random sampling method will be employed for determining the number of samples to be collected from the cored material. This approach will ensure detection of potentially contaminated material present in the disposal pits.

The indicator parameters for field screening at CAU 409 are VOCs. Field screening for VOCs will be accomplished using the HNu Model DL-101 Photoionization Analyzer. The manufacturer of the Model DL-101 claims a reproducibility of \pm 1 percent at a detection limit of 100 parts per billion in headspace air (as called for in Table A.2-2). This is assumed to be the relative standard deviation, or Coefficient of Variation (CV). 
SW-846 Method 8260B gives individual coefficients of variation for each analyte determined by the method. While these range from as low as 3.5 percent to as high as 39.6 percent for garden soil spiked at the $4 \mathrm{mg} / \mathrm{kg}$, the average $\mathrm{CV}$ is approximately 7.5 percent.

For the purposes of the CAU 409 investigation, the CV will be assumed to be 10 percent (i.e., more conservative reproducibility than the literature claims).

A relative error of 10-20 percent from the true mean at a confidence limit of 90 percent is considered acceptable for remedial response studies (EPA, 1989).

By substituting the appropriate values for $t$ (any of the values for the one-tailed Student's $t$ at the 90 percent confidence limit), $C V$ (10 percent) and $e_{r}$ (10 percent) into this equation and iterating the equation several times, the number of samples, $n$, converges to 2 . Since no meaningful statistical assessment can be conducted on the results of as few as two samples, the number of samples should be increased to three for the purposes of this investigation. Thus, collecting a minimum of three samples from each Septic Sludge Disposal Pit for laboratory analysis will allow the determination of the VOCs concentration within 10 percent of the true mean at a confidence limit of 90 percent.

$$
\boldsymbol{n}=\left(\boldsymbol{t}_{0.90, \mathrm{n}-1} \frac{C V}{e_{r}}\right)^{2}
$$

The number of samples required to characterize the site to an acceptable level of confidence will be calculated using Equation 8 from Chapter 9 of SW-846 (EPA, 1996). 


\section{A.7.0 References}

DOE/NV, see U.S. Department of Energy, Nevada Operations Office.

EPA, see U.S. Environmental Protection Agency.

Ecology and Environment, Inc. 1989. Federal Facility Preliminary Assessment Review of TTR Facilities. San Francisco, CA.

Elliston, J. 2000. Record of Telecon with B. McCall (ITLV) regarding the operational history of the Septic Tank Systems in Area 3, 3 May. Las Vegas, NV: IT Corporation.

FFACO, see Federal Facility Agreement and Consent Order.

Federal Facility Agreement and Consent Order. 1996 (as amended). Agreed to by the State of Nevada, the U.S. Department of Energy, and the U.S. Department of Defense.

IT, see IT Corporation.

IT Corporation. 1991. Tonopah Test Range Septic Tank Sampling and Analysis Final Report, September. Albuquerque, NM.

IT Corporation. 1994. Sandia National Laboratories / New Mexico, Septic Tank Monitoring Report, Tonopah Test Range and Nevada Test Site, June. Tonopah, NV.

IT Corporation. 1997. Initial Surface Geophysical Survey Report for the Tonopah Test Range Environmental Restoration Sites, Vol. 1 of 2, ITLV10972--93. Las Vegas, NV.

IT Corporation. 1998a. Field Form titled, "Phase I Assessment Form," 29 April. Las Vegas, NV.

IT Corporation. 1998b. Field Form titled, "Phase I Assessment Form," 4 September. Las Vegas, NV.

NAC, see Nevada Administrative Code.

Nevada Administrative Code. 1999. NAC445A.2272, "Contamination of Soil: Establishment of Action Levels." Carson City, NV: Nevada Division of Environmental Protection.

RSL, see Remote Sensing Laboratory.

Remote Sensing Laboratory. 1999. Aerial photograph Number 9997-28, 14 March. Nellis Air Force Base, NV: Photo Archive Library. 
SNL, see Sandia National Laboratories.

Sandia National Laboratories. 1992. Environmental Restoration Program Information Sheet. Las Vegas, NV.

U.S. Department of Energy, Nevada Operations Office. 1994. Resource Conservation Recovery Act Facility Investigation Work Plan for the U.S. Department of Energy Environmental Restoration Sites, Tonopah Test Range, Nevada, Volume 1, May. Las Vegas, NV.

U.S. Department of Energy, Nevada Operations Office. 1996a. Corrective Action Unit Work Plan, Tonopah Test Range, Nevada, Rev. 0, DOE/NV--443. Las Vegas, NV.

U.S. Department of Energy, Nevada Operations Office. 1996b. Final Environmental Impact Statement for the Nevada Test Site and Off-Site Locations in the State of Nevada, DOE/EIS 0243. Las Vegas, NV.

U.S. Department of Energy, Nevada Operations Office. 1996c. Industrial Sites Quality Assurance Project Plan, Rev. 1, DOE/NV--372. Las Vegas, NV.

U.S. Department of Energy, Nevada Operations Office. 1998. Work Plan for Leachfield Corrective Action Units: Nevada Test Site and Tonopah Test Range, Nevada, Rev. 1, DOE/NV--514. Las Vegas, NV.

U.S. Department of Energy, Nevada Operations Office. 2000. Sectored Clean-up Work Plan For Housekeeping Category Waste Sites, Rev. 0, DOE/NV--579. Las Vegas, NV.

U.S. Environmental Protection Agency. 1989. Soil Sampling Quality Assurance User's Guide, Second Edition, EPA/600/8-89/046. Washington, DC.

U.S. Environmental Protection Agency. 1996. Test Methods for Evaluating Solid Waste, Physical/Chemical Methods, SW-846, Third Edition, CD ROM, PB97-501928GEI (CD ROM includes revisions to 1986, 1992, and 1994). Washington, DC.

U.S. Environmental Protection Agency. 1999. Memo from S.J. Smucker to table mailing list regarding Region IX Preliminary Remediation Goals (PRGs), 1 October. San Francisco, CA. 
Appendix B

Project Organization 


\section{B.1.0 Project Organization}

The DOE/NV Industrial Sites Project Manager is Janet Appenzeller-Wing and her telephone number is (702) 295-0461.

The names of the project Health and Safety Officer and the Quality Assurance Officer can be found in the appropriate DOE/NV plan. However, personnel are subject to change, and it is suggested that the Project Manager be contacted for further information. The Task Manager will be identified in the FFACO Biweekly Activity Report prior to the start of field activities. 


\section{Appendix C}

\section{Analytical Table}


Table C.1-1

Laboratory Chemical, Toxicity Characteristic Leaching Procedure, and Radiochemistry Analytical Requirements for Industrial Sites (Page 1 of 6 )

\begin{tabular}{|c|c|c|c|c|c|c|}
\hline $\begin{array}{l}\text { Parameter or } \\
\text { Analyte }\end{array}$ & $\begin{array}{l}\text { Medium or } \\
\text { Matrix }\end{array}$ & $\begin{array}{l}\text { Analytical } \\
\text { Method }\end{array}$ & $\begin{array}{c}\text { Minimum } \\
\text { Reporting Limit }\end{array}$ & $\begin{array}{l}\text { Regulatory } \\
\text { Limit }\end{array}$ & $\begin{array}{c}\text { Relative } \\
\text { Percent } \\
\text { Difference } \\
\text { (RPD) }^{\mathrm{a}}\end{array}$ & $\begin{array}{c}\text { Percent } \\
\text { Recovery } \\
(\% R)^{b}\end{array}$ \\
\hline \multicolumn{7}{|c|}{$\overline{\text { ORGANICS }}$} \\
\hline \multirow{2}{*}{$\begin{array}{c}\text { Total Volatile } \\
\text { Organic Compounds } \\
\text { (VOCs) }\end{array}$} & Water & \multirow{2}{*}{$8260 \mathrm{~B}^{\mathrm{c}}$} & \multirow{2}{*}{$\begin{array}{c}\text { Analyte-specific } \\
\text { estimated } \\
\text { quantitation limits }^{d}\end{array}$} & \multirow{2}{*}{$\begin{array}{c}\text { Not Applicable } \\
\text { (NA) }\end{array}$} & $14^{\mathrm{e}}$ & $61-145^{e}$ \\
\hline & Soil & & & & $24^{\mathrm{e}}$ & $59-172^{e}$ \\
\hline \multicolumn{7}{|l|}{$\begin{array}{c}\text { Toxicity } \\
\text { Characteristic } \\
\text { Leaching Procedure } \\
\text { (TCLP) VOCs }\end{array}$} \\
\hline Benzene & \multirow{10}{*}{ Aqueous } & \multirow{10}{*}{$1311 / 8260 B^{c}$} & $0.050 \mathrm{mg} / \mathrm{L}^{\mathrm{d}}$ & $0.5 \mathrm{mg} / \mathrm{L}^{\mathrm{d}}$ & \multirow{10}{*}{$14^{\mathrm{e}}$} & \multirow{10}{*}{$61-145^{\mathrm{e}}$} \\
\hline $\begin{array}{c}\text { Carbon } \\
\text { Tetrachloride }\end{array}$ & & & $0.050 \mathrm{mg} / \mathrm{L}^{\mathrm{d}}$ & $0.5 \mathrm{mg} / \mathrm{L}^{d}$ & & \\
\hline Chlorobenzene & & & $0.050 \mathrm{mg} / \mathrm{L}^{\mathrm{d}}$ & $100 \mathrm{mg} / \mathrm{L}^{\mathrm{d}}$ & & \\
\hline Chloroform & & & $0.050 \mathrm{mg} / \mathrm{L}^{\mathrm{d}}$ & $6 \mathrm{mg} / \mathrm{L}^{\mathrm{d}}$ & & \\
\hline 1,2-Dichloroethane & & & $0.050 \mathrm{mg} / \mathrm{L}^{\mathrm{d}}$ & $0.5 \mathrm{mg} / \mathrm{L}^{d}$ & & \\
\hline 1,1-Dichloroethene & & & $0.050 \mathrm{mg} / \mathrm{L}^{\mathrm{d}}$ & $0.7 \mathrm{mg} / \mathrm{L}^{\mathrm{d}}$ & & \\
\hline Methyl Ethyl Ketone & & & $0.050 \mathrm{mg} / \mathrm{L}^{\mathrm{d}}$ & $200 \mathrm{mg} / \mathrm{L}^{\mathrm{d}}$ & & \\
\hline Tetrachloroethene & & & $0.050 \mathrm{mg} / \mathrm{L}^{\mathrm{d}}$ & $0.7 \mathrm{mg} / \mathrm{L}^{d}$ & & \\
\hline Trichloroethene & & & $0.050 \mathrm{mg} / \mathrm{L}^{d}$ & $0.5 \mathrm{mg} / \mathrm{L}^{d}$ & & \\
\hline Vinyl Chloride & & & $0.050 \mathrm{mg} / \mathrm{L}^{\mathrm{d}}$ & $0.2 \mathrm{mg} / \mathrm{L}^{d}$ & & \\
\hline \multirow{2}{*}{$\begin{array}{c}\text { Total Semivolatile } \\
\text { Organic Compounds } \\
\text { (SVOCs) }\end{array}$} & Water & \multirow{2}{*}{$8270 C^{c}$} & \multirow{2}{*}{$\begin{array}{c}\text { Analyte-specific } \\
\text { estimated } \\
\text { quantitation limits }\end{array}$} & \multirow{2}{*}{ NA } & $50^{e}$ & $9-127^{e}$ \\
\hline & Soil & & & & $50^{e}$ & $11-142^{\mathrm{e}}$ \\
\hline \multicolumn{7}{|l|}{ TCLP SVOCs } \\
\hline o-Cresol & \multirow{6}{*}{ Aqueous } & \multirow{6}{*}{$1311 / 8270 C^{c}$} & $0.10 \mathrm{mg} / \mathrm{L}^{d}$ & $200 \mathrm{mg} / \mathrm{L}^{\mathrm{d}}$ & \multirow{6}{*}{$50^{\mathrm{e}}$} & \multirow{6}{*}{$9-127^{e}$} \\
\hline $\mathrm{m}$-Cresol & & & $0.10 \mathrm{mg} / \mathrm{L}^{\mathrm{d}}$ & $200 \mathrm{mg} / \mathrm{L}^{\mathrm{d}}$ & & \\
\hline p-Cresol & & & $0.10 \mathrm{mg} / \mathrm{L}^{\mathrm{d}}$ & $200 \mathrm{mg} / \mathrm{L}^{\mathrm{d}}$ & & \\
\hline Cresol (total) & & & $0.30 \mathrm{mg} / \mathrm{L}^{\mathrm{d}}$ & $200 \mathrm{mg} / \mathrm{L}^{\mathrm{d}}$ & & \\
\hline $\begin{array}{l}\text { 1,4-Dichloro- } \\
\text { benzene }\end{array}$ & & & $0.10 \mathrm{mg} / \mathrm{L}^{d}$ & $7.5 \mathrm{mg} / \mathrm{L}^{\mathrm{d}}$ & & \\
\hline 2,4-Dinitrotoluene & & & $0.10 \mathrm{mg} / \mathrm{L}^{\mathrm{d}}$ & $0.13 \mathrm{mg} / \mathrm{L}^{\mathrm{d}}$ & & \\
\hline
\end{tabular}


Table C.1-1

Laboratory Chemical, Toxicity Characteristic Leaching Procedure, and Radiochemistry Analytical Requirements for Industrial Sites

(Page 2 of 6 )

\begin{tabular}{|c|c|c|c|c|c|c|}
\hline $\begin{array}{c}\text { Parameter or } \\
\text { Analyte }\end{array}$ & $\begin{array}{l}\text { Medium or } \\
\text { Matrix }\end{array}$ & $\begin{array}{l}\text { Analytical } \\
\text { Method }\end{array}$ & $\begin{array}{c}\text { Minimum } \\
\text { Reporting Limit }\end{array}$ & $\begin{array}{l}\text { Regulatory } \\
\text { Limit }\end{array}$ & $\begin{array}{c}\text { Relative } \\
\text { Percent } \\
\text { Difference } \\
\text { (RPD) }^{\mathrm{a}}\end{array}$ & $\begin{array}{c}\text { Percent } \\
\text { Recovery } \\
(\% R)^{b}\end{array}$ \\
\hline $\begin{array}{l}\text { Hexachloro- } \\
\text { benzene }\end{array}$ & \multirow{8}{*}{ Aqueous } & \multirow{8}{*}{$1311 / 8270 C^{c}$} & $0.10 \mathrm{mg} / \mathrm{L}^{\mathrm{d}}$ & $0.13 \mathrm{mg} / \mathrm{L}^{\mathrm{d}}$ & \multirow{8}{*}{$50^{\mathrm{e}}$} & \multirow{8}{*}{$9-127^{e}$} \\
\hline $\begin{array}{l}\text { Hexachloro- } \\
\text { butadiene }\end{array}$ & & & $0.10 \mathrm{mg} / \mathrm{L}^{\mathrm{d}}$ & $0.5 \mathrm{mg} / \mathrm{L}^{\mathrm{d}}$ & & \\
\hline $\begin{array}{l}\text { Hexachloro- } \\
\text { ethane }\end{array}$ & & & $0.10 \mathrm{mg} / \mathrm{L}^{\mathrm{d}}$ & $3 \mathrm{mg} / \mathrm{L}^{\mathrm{d}}$ & & \\
\hline Nitrobenzene & & & $0.10 \mathrm{mg} / \mathrm{L}^{\mathrm{d}}$ & $2 \mathrm{mg} / \mathrm{L}^{\mathrm{d}}$ & & \\
\hline $\begin{array}{l}\text { Pentachloro- } \\
\text { phenol }\end{array}$ & & & $0.50 \mathrm{mg} / \mathrm{L}^{\mathrm{d}}$ & $100 \mathrm{mg} / \mathrm{L}^{\mathrm{d}}$ & & \\
\hline Pyridine & & & $0.10 \mathrm{mg} / \mathrm{L}^{\mathrm{d}}$ & $5 \mathrm{mg} / \mathrm{L}^{\mathrm{d}}$ & & \\
\hline $\begin{array}{l}\text { 2,4,5-Trichloro- } \\
\text { phenol }\end{array}$ & & & $0.10 \mathrm{mg} / \mathrm{L}^{\mathrm{d}}$ & $400 \mathrm{mg} / \mathrm{L}^{\mathrm{d}}$ & & \\
\hline $\begin{array}{l}\text { 2,4,6-Trichloro- } \\
\text { phenol }\end{array}$ & & & $0.10 \mathrm{mg} / \mathrm{L}^{\mathrm{d}}$ & $2 \mathrm{mg} / \mathrm{L}^{\mathrm{d}}$ & & \\
\hline \multirow{2}{*}{$\begin{array}{c}\text { Total } \\
\text { Pesticides }\end{array}$} & Water & \multirow{2}{*}{$8081 A^{c}$} & \multirow{2}{*}{$\begin{array}{l}\text { Analyte-specific } \\
(\mathrm{CRQL})^{\mathrm{e}}\end{array}$} & \multirow{2}{*}{ NA } & $27^{e}$ & $38-131^{e}$ \\
\hline & Soil & & & & $50^{e}$ & $23-139^{e}$ \\
\hline \multicolumn{7}{|l|}{$\begin{array}{c}\text { TCLP } \\
\text { Pesticides }\end{array}$} \\
\hline Chlordane & \multirow{7}{*}{ Aqueous } & \multirow{7}{*}{$1311 / 8081 A^{c}$} & $0.0005 \mathrm{mg} / \mathrm{L}^{\mathrm{e}}$ & $0.03 \mathrm{mg} / \mathrm{L}^{d}$ & \multirow{7}{*}{$27^{e}$} & \multirow{7}{*}{$38-131^{e}$} \\
\hline Endrin & & & $0.001 \mathrm{mg} / \mathrm{L}^{\mathrm{e}}$ & $0.02 \mathrm{mg} / \mathrm{L}^{\mathrm{d}}$ & & \\
\hline Heptachlor & & & $0.0005 \mathrm{mg} / \mathrm{L}^{\mathrm{e}}$ & $0.008 \mathrm{mg} / \mathrm{L}^{d}$ & & \\
\hline $\begin{array}{l}\text { Heptachlor } \\
\text { Epoxide }\end{array}$ & & & $0.0005 \mathrm{mg} / \mathrm{L}^{\mathrm{e}}$ & $0.008 \mathrm{mg} / \mathrm{L}^{\mathrm{d}}$ & & \\
\hline $\begin{array}{c}\text { Gamma-BHC } \\
\text { (Lindane) }\end{array}$ & & & $0.0005 \mathrm{mg} / \mathrm{L}^{\mathrm{e}}$ & $0.4 \mathrm{mg} / \mathrm{L}^{\mathrm{d}}$ & & \\
\hline Methoxychlor & & & $0.005 \mathrm{mg} / \mathrm{L}^{\mathrm{e}}$ & $10 \mathrm{mg} / \mathrm{L}^{\mathrm{d}}$ & & \\
\hline Toxaphene & & & $0.05 \mathrm{mg} / \mathrm{L}^{\mathrm{e}}$ & $0.5 \mathrm{mg} / \mathrm{L}^{\mathrm{d}}$ & & \\
\hline \multirow[b]{2}{*}{$\begin{array}{l}\text { Polychlorinated } \\
\text { Biphenyls (PCBs) }\end{array}$} & Water & \multirow[b]{2}{*}{$8082^{c}$} & \multirow{2}{*}{$\begin{array}{c}\text { Analyte-specific } \\
\text { contract-required } \\
\text { quantitation limits } \\
(\mathrm{CRQL})^{\mathrm{e}}\end{array}$} & \multirow[b]{2}{*}{ NA } & \multirow[b]{2}{*}{ Lab-specific $^{\dagger}$} & \multirow[b]{2}{*}{ Lab-specific } \\
\hline & Soil & & & & & \\
\hline \multirow{2}{*}{$\begin{array}{c}\text { Total } \\
\text { Herbicides }\end{array}$} & Water & \multirow{2}{*}{$8151 A^{c}$} & $1.3 \mu \mathrm{g} / \mathrm{L}^{\mathrm{c}}$ & \multirow{2}{*}{ NA } & \multirow{2}{*}{ Lab-specific $^{f}$} & \multirow{2}{*}{ Lab-specific $^{t}$} \\
\hline & Soil & & $66 \mu \mathrm{g} / \mathrm{kg}^{\mathrm{c}}$ & & & \\
\hline $\begin{array}{c}\text { TCLP } \\
\text { Herbicides }\end{array}$ & & & & & & \\
\hline
\end{tabular}


Table C.1-1

Laboratory Chemical, Toxicity Characteristic Leaching Procedure, and Radiochemistry Analytical Requirements for Industrial Sites

(Page 3 of 6 )

\begin{tabular}{|c|c|c|c|c|c|c|}
\hline $\begin{array}{l}\text { Parameter or } \\
\text { Analyte }\end{array}$ & $\begin{array}{l}\text { Medium or } \\
\text { Matrix }\end{array}$ & $\begin{array}{l}\text { Analytical } \\
\text { Method }\end{array}$ & $\begin{array}{c}\text { Minimum } \\
\text { Reporting Limit }\end{array}$ & $\begin{array}{l}\text { Regulatory } \\
\text { Limit }\end{array}$ & $\begin{array}{c}\text { Relative } \\
\text { Percent } \\
\text { Difference } \\
\text { (RPD) }^{\mathrm{a}}\end{array}$ & $\begin{array}{l}\text { Percent } \\
\text { Recovery } \\
(\% R)^{b}\end{array}$ \\
\hline $2,4-D$ & \multirow{2}{*}{ Aqueous } & \multirow{2}{*}{$1311 / 8151 A^{c}$} & $0.002 \mathrm{mg} / \mathrm{L}^{\mathrm{d}}$ & $10 \mathrm{mg} / \mathrm{L}^{\mathrm{d}}$ & \multirow{2}{*}{ Lab-specific $^{\dagger}$} & \multirow{2}{*}{ Lab-specific } \\
\hline 2,4,5-TP & & & $0.00075 \mathrm{mg} / \mathrm{L}^{\mathrm{d}}$ & $1 \mathrm{mg} / \mathrm{L}^{\mathrm{d}}$ & & \\
\hline \multirow{4}{*}{$\begin{array}{c}\text { Total Petroleum } \\
\text { Hydrocarbons (TPH) }\end{array}$} & $\begin{array}{c}\text { Water } \\
\text { Gasoline }\end{array}$ & \multirow{4}{*}{ 8015B modified ${ }^{c}$} & $0.1 \mathrm{mg} / \mathrm{L}^{\mathrm{g}}$ & \multirow{4}{*}{ NA } & \multirow{4}{*}{ Lab-specific $^{\dagger}$} & \multirow{4}{*}{ Lab-specific } \\
\hline & Soil Gasoline & & $0.5 \mathrm{mg} / \mathrm{kg}^{\mathrm{g}}$ & & & \\
\hline & Water Diesel & & $0.5 \mathrm{mg} / \mathrm{L}^{\mathrm{g}}$ & & & \\
\hline & Soil Diesel & & $25 \mathrm{mg} / \mathrm{kg}^{\mathrm{g}}$ & & & \\
\hline \multirow{2}{*}{$\begin{array}{l}\text { Polychlorinated } \\
\text { Dioxins and Furans }\end{array}$} & Water & \multirow{2}{*}{$8280 \mathrm{~A} / 8290^{\circ}$} & $0.05 \mu \mathrm{g} / \mathrm{L}^{\mathrm{c}}$ & \multirow{2}{*}{ NA } & \multirow{2}{*}{ Lab-specific ${ }^{f}$} & \multirow{2}{*}{ Lab-specific $^{\dagger}$} \\
\hline & Soil & & $5 \mu \mathrm{g} / \mathrm{kg}^{\mathrm{c}}$ & & & \\
\hline \multicolumn{7}{|c|}{ INORGANICS } \\
\hline \multicolumn{7}{|l|}{$\begin{array}{c}\text { Total Resource } \\
\text { Conservation and } \\
\text { Recovery Act } \\
\text { (RCRA) Metals }\end{array}$} \\
\hline \multirow{2}{*}{ Arsenic } & Water & $6010 \mathrm{~B} / 7470 \mathrm{~A}^{\mathrm{c}}$ & $10 \mu \mathrm{g} / \mathrm{L}^{\mathrm{g}, \mathrm{h}}$ & \multirow{16}{*}{ NA } & \multirow{16}{*}{$20^{\mathrm{h}}$} & \multirow{16}{*}{$75-125^{\mathrm{h}}$} \\
\hline & Soil & $6010 \mathrm{~B} / 7471 \mathrm{~A}^{\mathrm{c}}$ & $1 \mathrm{mg} / \mathrm{kg}^{\mathrm{g}, \mathrm{h}}$ & & & \\
\hline \multirow{2}{*}{ Barium } & Water & $6010 \mathrm{~B} / 7470 \mathrm{~A}^{\mathrm{c}}$ & $200 \mu \mathrm{g} / \mathrm{L}^{\mathrm{g}, \mathrm{h}}$ & & & \\
\hline & Soil & $6010 \mathrm{~B} / 7471 \mathrm{~A}^{\mathrm{c}}$ & $20 \mathrm{mg} / \mathrm{kg}^{\mathrm{g}, \mathrm{h}}$ & & & \\
\hline \multirow{2}{*}{ Cadmium } & Water & $6010 \mathrm{~B} / 7470 \mathrm{~A}^{\mathrm{c}}$ & $5 \mu \mathrm{g} / \mathrm{L}^{\mathrm{g}, \mathrm{h}}$ & & & \\
\hline & Soil & $6010 \mathrm{~B} / 7471 \mathrm{~A}^{\mathrm{c}}$ & $0.5 \mathrm{mg} / \mathrm{kg}^{\mathrm{g}, \mathrm{h}}$ & & & \\
\hline \multirow{2}{*}{ Chromium } & Water & $6010 \mathrm{~B} / 7470 \mathrm{~A}^{\mathrm{c}}$ & $10 \mu \mathrm{g} / \mathrm{L}^{\mathrm{g}, \mathrm{h}}$ & & & \\
\hline & Soil & $6010 \mathrm{~B} / 7471 \mathrm{~A}^{\mathrm{c}}$ & $1 \mathrm{mg} / \mathrm{kg}^{\mathrm{g}, \mathrm{h}}$ & & & \\
\hline \multirow{2}{*}{ Lead } & Water & $6010 \mathrm{~B} / 7470 \mathrm{~A}^{\mathrm{c}}$ & $3 \mu \mathrm{g} / \mathrm{L}^{\mathrm{g}, \mathrm{h}}$ & & & \\
\hline & Soil & $6010 \mathrm{~B} / 7471 \mathrm{~A}^{\mathrm{c}}$ & $0.3 \mathrm{mg} / \mathrm{kg}^{\mathrm{g}, \mathrm{h}}$ & & & \\
\hline \multirow{2}{*}{ Mercury } & Water & $6010 \mathrm{~B} / 7470 \mathrm{~A}^{\mathrm{c}}$ & $0.2 \mu \mathrm{g} / \mathrm{L}^{\mathrm{g}, \mathrm{h}}$ & & & \\
\hline & Soil & $6010 \mathrm{~B} / 7471 \mathrm{~A}^{\mathrm{c}}$ & $0.1 \mathrm{mg} / \mathrm{kg}^{\mathrm{g}, \mathrm{h}}$ & & & \\
\hline \multirow{2}{*}{ Selenium } & Water & $6010 \mathrm{~B} / 7470 \mathrm{~A}^{\mathrm{c}}$ & $5 \mu \mathrm{g} / \mathrm{L}^{\mathrm{g}, \mathrm{h}}$ & & & \\
\hline & Soil & $6010 \mathrm{~B} / 7471 \mathrm{~A}^{\mathrm{c}}$ & $0.5 \mathrm{mg} / \mathrm{kg}^{\mathrm{g}, \mathrm{h}}$ & & & \\
\hline \multirow{2}{*}{ Silver } & Water & $6010 \mathrm{~B} / 7470 \mathrm{~A}^{\mathrm{c}}$ & $10 \mu \mathrm{g} / \mathrm{L}^{\mathrm{g}, \mathrm{h}}$ & & & \\
\hline & Soil & $6010 \mathrm{~B} / 7471 \mathrm{~A}^{\mathrm{c}}$ & $1 \mathrm{mg} / \mathrm{kg}^{\mathrm{g}, \mathrm{h}}$ & & & \\
\hline
\end{tabular}


Table C.1-1

Laboratory Chemical, Toxicity Characteristic Leaching Procedure, and Radiochemistry Analytical Requirements for Industrial Sites

(Page 4 of 6)

\begin{tabular}{|c|c|c|c|c|c|c|}
\hline $\begin{array}{l}\text { Parameter or } \\
\text { Analyte }\end{array}$ & $\begin{array}{l}\text { Medium or } \\
\text { Matrix }\end{array}$ & $\begin{array}{l}\text { Analytical } \\
\text { Method }\end{array}$ & $\begin{array}{c}\text { Minimum } \\
\text { Reporting Limit }\end{array}$ & $\begin{array}{l}\text { Regulatory } \\
\text { Limit }\end{array}$ & $\begin{array}{c}\text { Relative } \\
\text { Percent } \\
\text { Difference } \\
\text { (RPD) }^{\mathrm{a}}\end{array}$ & $\begin{array}{c}\text { Percent } \\
\text { Recovery } \\
(\% R)^{\mathrm{b}}\end{array}$ \\
\hline \multicolumn{7}{|l|}{$\begin{array}{l}\text { TCLP RCRA } \\
\text { Metals }\end{array}$} \\
\hline Arsenic & \multirow{8}{*}{ Aqueous } & \multirow{8}{*}{$\begin{array}{l}1311 / 6010 B^{c} \\
1311 / 7470 A^{c}\end{array}$} & $0.10 \mathrm{mg} / \mathrm{L}^{\mathrm{g}, \mathrm{h}}$ & $5 \mathrm{mg} / \mathrm{L}^{\mathrm{d}}$ & \multirow{8}{*}{$20^{h}$} & \multirow{8}{*}{$75-125^{h}$} \\
\hline Barium & & & $2 \mathrm{mg} / \mathrm{L}^{\mathrm{g}, \mathrm{h}}$ & $100 \mathrm{mg} / \mathrm{L}^{d}$ & & \\
\hline Cadmium & & & $0.05 \mathrm{mg} / \mathrm{L}^{\mathrm{g}, \mathrm{h}}$ & $1 \mathrm{mg} / \mathrm{L}^{\mathrm{d}}$ & & \\
\hline Chromium & & & $0.10 \mathrm{mg} / \mathrm{L}^{\mathrm{g}, \mathrm{h}}$ & $5 \mathrm{mg} / \mathrm{L}^{\mathrm{d}}$ & & \\
\hline Lead & & & $0.03 \mathrm{mg} / \mathrm{L}^{\mathrm{g}, \mathrm{h}}$ & $5 \mathrm{mg} / \mathrm{L}^{\mathrm{d}}$ & & \\
\hline Mercury & & & $0.002 \mathrm{mg} / \mathrm{L}^{\mathrm{g}, \mathrm{h}}$ & $0.2 \mathrm{mg} / \mathrm{L}^{\mathrm{d}}$ & & \\
\hline Selenium & & & $0.05 \mathrm{mg} / \mathrm{L}^{\mathrm{g}, \mathrm{h}}$ & $1 \mathrm{mg} / \mathrm{L}^{\mathrm{d}}$ & & \\
\hline Silver & & & $0.10 \mathrm{mg} / \mathrm{L}^{\mathrm{g}, \mathrm{h}}$ & $5 \mathrm{mg} / \mathrm{L}^{\mathrm{d}}$ & & \\
\hline \multirow{2}{*}{ Cyanide } & Water & \multirow{2}{*}{$9010 \mathrm{~B}^{\mathrm{c}}$} & $0.01 \mathrm{mg} / \mathrm{L}^{\mathrm{h}}$ & \multirow{2}{*}{ NA } & \multirow{2}{*}{$20^{h}$} & \multirow{2}{*}{$75-125^{h}$} \\
\hline & Soil & & $1.0 \mathrm{mg} / \mathrm{kg}^{\mathrm{h}}$ & & & \\
\hline \multirow[b]{2}{*}{ Sulfide } & Water & \multirow[b]{2}{*}{$9030 \mathrm{~B} / 9034^{\mathrm{c}}$} & $0.4 \mathrm{mg} / \mathrm{L}^{\mathrm{c}}$ & \multirow[b]{2}{*}{ NA } & \multirow[b]{2}{*}{ Lab-specific $^{\dagger}$} & \multirow[b]{2}{*}{ Lab-specific $^{\dagger}$} \\
\hline & $\begin{array}{c}\text { Soil or } \\
\text { Sediment }\end{array}$ & & $10 \mathrm{mg} / \mathrm{kg}^{\mathrm{g}}$ & & & \\
\hline \multirow{2}{*}{$\mathrm{pH} /$ Corrosivity } & Water & $9040 \mathrm{~B}^{\mathrm{c}}$ & \multirow{2}{*}{ NA } & $\mathrm{pH}>2^{\mathrm{i}}$ & \multirow{2}{*}{ Lab-specific $^{\dagger}$} & \multirow{2}{*}{ Lab-specific $^{\dagger}$} \\
\hline & Soil & $9045 C^{c}$ & & $\mathrm{pH}<12.5^{\mathrm{i}}$ & & \\
\hline \multirow[b]{2}{*}{ Ignitability } & Water & $1010^{c}$ & \multirow[b]{2}{*}{ NA } & $\begin{array}{c}\text { Flash Point } \\
<140^{\circ} \mathrm{F}^{\mathrm{d}}\end{array}$ & \multirow[b]{2}{*}{ NA } & \multirow[b]{2}{*}{ NA } \\
\hline & Soil & $1030^{c}$ & & $\begin{array}{c}\text { Burn Rate } \\
>2.2 \mathrm{~mm} / \mathrm{sec} \\
\text { nonmetals; } \\
>0.17 \mathrm{~mm} / \mathrm{sec} \\
\text { metals }\end{array}$ & & \\
\hline
\end{tabular}


Table C.1-1

Laboratory Chemical, Toxicity Characteristic Leaching Procedure, and Radiochemistry Analytical Requirements for Industrial Sites

(Page 5 of 6 )

\begin{tabular}{|c|c|c|c|c|c|c|}
\hline $\begin{array}{l}\text { Parameter or } \\
\text { Analyte }\end{array}$ & $\begin{array}{l}\text { Medium or } \\
\text { Matrix }\end{array}$ & $\begin{array}{l}\text { Analytical } \\
\text { Method }\end{array}$ & $\begin{array}{c}\text { Minimum } \\
\text { Reporting Limit }\end{array}$ & $\begin{array}{l}\text { Regulatory } \\
\text { Limit }\end{array}$ & $\begin{array}{c}\text { Relative } \\
\text { Percent } \\
\text { Difference } \\
\text { (RPD) }{ }^{\mathrm{a}}\end{array}$ & $\begin{array}{c}\text { Percent } \\
\text { Recovery } \\
(\% \mathrm{R})^{\mathrm{b}}\end{array}$ \\
\hline \multicolumn{7}{|c|}{ RADIOCHEMISTRY } \\
\hline \multirow{2}{*}{$\begin{array}{l}\text { Gamma-Emitting } \\
\text { Radionuclides }\end{array}$} & Water & EPA $901.1^{k}$ & \multirow{2}{*}{ Isotope-specific ${ }^{m}$} & \multirow{2}{*}{ NA } & 20 & \multirow{8}{*}{$\begin{array}{c}\text { Tracer Yield } \\
30-105 \\
\text { Laboratory } \\
\text { Control } \\
\text { Sample Yield } \\
80-120\end{array}$} \\
\hline & Soil & HASL $300^{\prime}$ & & & 35 & \\
\hline \multirow{2}{*}{$\begin{array}{l}\text { Isotopic } \\
\text { Plutonium }\end{array}$} & Water & $\begin{array}{c}\text { HASL } 300^{\prime} \\
\text { or } \\
\text { ASTM } \\
\text { D3865- } 97^{n, o}\end{array}$ & $0.1 \mathrm{pCi} / \mathrm{L}$ & \multirow{2}{*}{ NA } & 20 & \\
\hline & Soil & $\begin{array}{c}\text { HASL } 300^{\prime} \\
\text { or } \\
\text { ASTM } \\
\text { C1001-90 }\end{array}$ & $0.05 \mathrm{pCi} / \mathrm{g}^{\mathrm{p}}$ & & 35 & \\
\hline \multirow{2}{*}{$\begin{array}{l}\text { Isotopic } \\
\text { Uranium }\end{array}$} & Water & $\begin{array}{c}\text { HASL } 300^{\prime} \\
\text { or } \\
\text { ASTM } \\
\text { D3972- } 97^{n, o}\end{array}$ & $0.1 \mathrm{pCi} / \mathrm{L}$ & \multirow{2}{*}{ NA } & 20 & \\
\hline & Soil & $\begin{array}{c}\text { HASL } 300^{\prime} \\
\text { or } \\
\text { ASTM } \\
\text { C1000-90 }\end{array}$ & $0.05 \mathrm{pCi} / \mathrm{g}$ & & 35 & \\
\hline \multirow{2}{*}{ Strontium - $90^{\mathrm{j}}$} & Water & $\begin{array}{l}\text { ASTM D } \\
5811-95^{n, 0}\end{array}$ & $1 \mathrm{pCi} / \mathrm{L}$ & \multirow{2}{*}{ NA } & 20 & \\
\hline & Soil & $\begin{array}{l}\text { ASTM D } \\
5811-95^{n, 0}\end{array}$ & $0.5 \mathrm{pCi} / \mathrm{g}^{\mathrm{q}}$ & & 35 & \\
\hline \multirow[b]{2}{*}{ Gross Alpha } & Water & EPA $900.0^{k}$ & $4 \mathrm{pCi} / \mathrm{L}$ & \multirow[b]{2}{*}{ NA } & 20 & Tracer Yield \\
\hline & Soil & SM $7110^{r}$ & $4 \mathrm{pCi} / \mathrm{g}$ & & 35 & $\begin{array}{l}\text { Laboratory } \\
\text { Control } \\
\text { Sample Yield } \\
80-120\end{array}$ \\
\hline \multirow[b]{2}{*}{ Gross Beta } & Water & EPA $900.0^{k}$ & $4 \mathrm{pCi} / \mathrm{L}$ & \multirow[b]{2}{*}{ NA } & 20 & \multirow{2}{*}{$\begin{array}{c}\text { Tracer Yield } \\
\text { 30-105 } \\
\text { Laboratory } \\
\text { Control } \\
\text { Sample Yield } \\
80-120\end{array}$} \\
\hline & Soil & SM $7110^{r}$ & $4 \mathrm{pCi} / \mathrm{g}$ & & 35 & \\
\hline
\end{tabular}




\section{Table C.1-1 \\ Laboratory Chemical, Toxicity Characteristic Leaching Procedure, and Radiochemistry Analytical Requirements for Industrial Sites} (Page 6 of 6 )

aRPD is used to Calculate Precision.

Precision is estimated from the relative percent difference of the concentrations measured for the matrix spike and matrix spike duplicate analyses of unspiked field samples, or field duplicates of unspiked samples. It is calculated by: $R P D=100 \times\left\{\left(\left|C_{1}-C_{2}\right|\right) /\left[\left(C_{1}+C_{2}\right) / 2\right]\right\}$, where $C_{1}=$ Concentration of the analyte in the first sample aliquot, $C_{2}=$ Concentration of the analyte in the second sample aliquot.

bo $\mathrm{R}$ is used to Calculate Accuracy.

Accuracy is assessed from the recovery of analytes spiked into a blank or sample matrix of interest, or from the recovery of surrogate compounds spiked into each sample. The recovery of each spiked analyte is calculated by: $\% R=100 \times\left(C_{s}-C_{u} / C_{n}\right)$, where $C_{s}=$ Concentration of the analyte in the spiked sample, $C_{u}=$ Concentration of the analyte in the unspiked sample, $\mathrm{C}_{\mathrm{n}}=$ Concentration increase that should result from spiking the sample.

'U.S. Environmental Protection Agency's (EPAs) Test Methods for Evaluating Solid Waste, 3rd Edition, Parts 1-4, SW-846 (EPA, 1996)

dEstimated Quantitation Limit as given in SW-846 (EPA, 1996)

eEPA Contract Laboratory Program Statement of Work for Organic Analysis (EPA, 1988b; 1991; and 1994b)

' In-House Generated RPD and \%R Performance Criteria

It is necessary for laboratories to develop in-house performance criteria and compare them to those in the methods. The laboratory begins by analyzing 15-20 samples of each matrix and calculating the mean \%R for each analyte. The standard deviation (SD) of each \%R is then calculated, and the warning and control limits for each analyte are established at \pm 2 SD and $\pm 3 \mathrm{SD}$ from the mean, respectively. If the warning limit is exceeded during the analysis of any sample delivery group (SDG), the laboratory institutes corrective action to bring the analytical system back into control. If the control limit is exceeded, the sample results for that SDG are considered unacceptable. These limits are reviewed after every 20-30 field samples of the same matrix and are updated at least semiannually. The laboratory tracks trends in both performance and control limits by the use of control charts. The laboratory's compliance with these requirements is confirmed as part of an annual laboratory audit. Similar procedures are followed in order to generate acceptance criteria for precision measurements.

IIndustrial Sites Quality Assurance Project Plan (DOE/NV, 1996)

hEPA Contract Laboratory Program Statement of Work for Inorganic Analysis (EPA, 1988a, 1994a, and 1995) 'RCRA Regulations and Keyword Index, 1998 Edition

IIsotopic minimum detectable concentrations are defined during the DQO process and specified in the CAIP as applicable.

${ }^{k}$ Prescribed Procedures for Measurements of Radioactivity in Drinking Water (EPA, 1980) or equivalent method

'Environmental Measurements Laboratory Procedures Manual (DOE, 1997) or equivalent method

mIsotope-Specific Minimum Reporting Limit to be specified in CAIP

"Or equivalent method approved by IT Las Vegas Analytical Services

${ }^{\circ}$ American Society for Testing and Materials

${ }^{\mathrm{P}}$ The Nevada Test Site Performance Objective Criteria requirement for certifying that hazardous waste has no added radioactivity requires that the total plutonium (the sum of the Pu-238, 239, 240 concentrations) not exceed $0.5 \mathrm{pCi} / \mathrm{g}$ (BN, 1995).

व The $1.0 \mathrm{pCi} / \mathrm{g}$ concentration is approximately twice the concentration of fallout $\mathrm{Sr}-90$ in background surface soils reported in the Environmental Monitoring Report for the Proposed Ward Valley California Low-Level Radioactive Waste Facility (Atlan-Tech, 1992).

'Standard Methods for the Examination of Water and Waste Water (APHA, 1995) or equivalent method

Definitions:

$\mu \mathrm{g} / \mathrm{kg}=$ Microgram(s) per kilogram $\mathrm{mg} / \mathrm{kg}=$ Milligram(s) per kilogram

$\mathrm{pCi} / \mathrm{L}=$ Picocurie(s) per liter $\mathrm{mg} / \mathrm{L}=$ Milligram(s) per liter $\mathrm{pCi} / \mathrm{g}=$ Picocurie(s) per gram $\mu \mathrm{g} / \mathrm{L}=\operatorname{Microgram}(\mathrm{s})$ per liter 


\section{C.1.0 References}

APHA, see American Public Health Association.

American Public Health Association. 1995. Standard Methods for the Examination of Water and Waste Water, 19th Edition. Washington, DC.

Atlan-Tech. 1992. Environmental Monitoring Report for the Proposed Ward Valley, California Low-Level Radioactive Waste Facility. Roswell, GA.

BN, see Bechtel Nevada.

Bechtel Nevada. 1995. Nevada Test Site Performance Objective for Certification of Nonradioactive Hazardous Waste, Rev. 0, G-E11/96.01. Las Vegas, NV.

RCRA Regulations and Keyword Index. 1998. ISSN 1074-1364. New York, NY: Elsevier Science, Inc.

U.S. Department of Energy. 1997. Environmental Measurements Laboratory Procedures Manual, HASL-300, 28th Edition, Vol. 1. New York, NY.

U.S. Department of Energy, Nevada Operations Office. 1996. Industrial Sites Quality Assurance Project Plan, Nevada Test Site, Nevada, DOE/NV--372. Las Vegas, NV.

U.S. Environmental Protection Agency. 1980. Prescribed Procedures for Measurements of Radioactivity in Drinking Water, EPA-600/4-80-032. Washington, DC.

U.S. Environmental Protection Agency. 1988a. Contract Laboratory Program Statement of Work for Inorganic Analysis, SOW No. 788, EPA/540/R-94/093. Washington, DC.

U.S. Environmental Protection Agency. 1988b. Contract Laboratory Program Statement of Work for Organic Analysis, SOW No. 2/88, EPA/540/R-94/096. Washington, DC.

U.S. Environmental Protection Agency. 1991. Contract Laboratory Program Statement of Work for Organic Analysis, OLMO 1.8, EPA/540/R-94/078. Washington, DC.

U.S. Environmental Protection Agency. 1994a. Contract Laboratory Program Statement of Work for Inorganic Analysis, ILMO 3.0, EPA/540/R-94/076. Washington, DC.

U.S. Environmental Protection Agency. 1994b. Contract Laboratory Program Statement of Work for Organic Analysis, OLMO 3.1, EPA/540/R-94/073. Washington, DC. 
U.S. Environmental Protection Agency. 1995. Contract Laboratory Program Statement of Work for Inorganic Analysis, ILMO 4.0, EPA/540/R-95/121. Washington, DC.

U.S. Environmental Protection Agency. 1996. Test Methods for Evaluating Solid Waste, Physical/Chemical Methods, SW-846, $3^{\text {rd }}$ Edition (which includes updates to 1986, 1992, and 1994 revisions), CD-ROM PB97-501928GEI. Washington, DC. 


\section{Appendix D}

\section{Summary of Analytical Results}


Table D-1

Summary of Analytical Results for Detected Parameters, Tonopah Test Range, Septic Tank Sampling 1991 Sampling Event ${ }^{1}$

(Page 1 of 3 )

\begin{tabular}{|c|c|c|c|c|c|c|c|c|c|}
\hline Parameter & Units & $33-1 A$ & 33-1B & $33-1 C$ & $33-2$ & $33-3$ & $33-8$ & 33-8 DUP & $33-10$ \\
\hline \multicolumn{10}{|c|}{ Volatile Organics } \\
\hline Acetone & $\mu g / L$ & -- & -- & 49 & -- & 34 & $\begin{array}{c}230.0^{2} \\
(\mu \mathrm{g} / \mathrm{kg})\end{array}$ & $\begin{array}{l}270.00 \\
(\mu \mathrm{g} / \mathrm{kg})\end{array}$ & $100^{3}$ \\
\hline 2-Butanone & $\mu \mathrm{g} / \mathrm{L}$ & -- & -- & -- & -- & -- & $\begin{array}{c}62.0 \\
(\mu \mathrm{g} / \mathrm{kg})\end{array}$ & $\begin{array}{c}59.0 \\
(\mu \mathrm{g} / \mathrm{kg})\end{array}$ & 49 \\
\hline Ethylbenzene & $\mu \mathrm{g} / \mathrm{L}$ & -- & -- & -- & -- & -- & -- & -- & 60 \\
\hline Toluene & $\mu g / L$ & -- & -- & -- & -- & 220 & $\begin{array}{c}41.0 \\
(\mu \mathrm{g} / \mathrm{kg})\end{array}$ & -- & 92 \\
\hline Xylenes & $\mu \mathrm{g} / \mathrm{L}$ & -- & -- & -- & 12 & -- & -- & -- & 270 \\
\hline $\begin{array}{c}\text { Total Toxic } \\
\text { Organics }\end{array}$ & $\mu g / L$ & -- & -- & -- & -- & 220 & $\begin{array}{c}41 \\
(\mu \mathrm{g} / \mathrm{kg})\end{array}$ & -- & 17152 \\
\hline \multicolumn{10}{|c|}{ Semivolatile Organics } \\
\hline 4-Methylphenol & $\mu \mathrm{g} / \mathrm{L}$ & -- & -- & 1000 & -- & -- & -- & -- & 17000 \\
\hline Naphthalene & $\mu \mathrm{g} / \mathrm{L}$ & -- & -- & 430 & -- & -- & -- & -- & -- \\
\hline \multicolumn{10}{|c|}{ Metals } \\
\hline Arsenic & $\mathrm{mg} / \mathrm{L}$ & 0.015 & 0.016 & -- & 0.015 & 0.019 & $\begin{array}{c}2.7 \\
(\mathrm{mg} / \mathrm{kg})\end{array}$ & $\begin{array}{c}2.3 \\
(\mathrm{mg} / \mathrm{kg})\end{array}$ & 0.048 \\
\hline Barium & $\mathrm{mg} / \mathrm{L}$ & 0.036 & 0.33 & 0.64 & 0.039 & 0.17 & $\begin{array}{c}127.0 \\
(\mathrm{mg} / \mathrm{kg})\end{array}$ & $\begin{array}{c}117.0 \\
(\mathrm{mg} / \mathrm{kg})\end{array}$ & 1.9 \\
\hline Cadmium & $\mathrm{mg} / \mathrm{L}$ & -- & 0.011 & 0.0098 & -- & 0.0074 & $\begin{array}{c}0.63 \\
(\mathrm{mg} / \mathrm{kg})\end{array}$ & $\begin{array}{c}1.5 \\
(\mathrm{mg} / \mathrm{kg})\end{array}$ & 0.086 \\
\hline Chromium & $\mathrm{mg} / \mathrm{L}$ & -- & 0.021 & 0.013 & -- & 0.013 & $\begin{array}{c}3.8^{4} \\
(\mathrm{mg} / \mathrm{kg})\end{array}$ & $\begin{array}{c}2.2 \\
(\mathrm{mg} / \mathrm{kg})\end{array}$ & 0.23 \\
\hline Copper & $\mathrm{mg} / \mathrm{L}$ & 0.026 & 0.14 & 0.20 & 0.070 & 0.18 & $\begin{array}{c}19.0 \\
(\mathrm{mg} / \mathrm{kg})\end{array}$ & $\begin{array}{c}25.1 \\
(\mathrm{mg} / \mathrm{kg})\end{array}$ & 6.4 \\
\hline
\end{tabular}


Table D-1

Summary of Analytical Results for Detected Parameters, Tonopah Test Range, Septic Tank Sampling 1991 Sampling Event ${ }^{1}$

(Page 2 of 3 )

\begin{tabular}{|c|c|c|c|c|c|c|c|c|c|}
\hline Parameter & Units & $33-1 A$ & 33-1B & $33-1 C$ & $33-2$ & $33-3$ & $33-8$ & 33-8 DUP & $33-10$ \\
\hline Lead & $\mathrm{mg} / \mathrm{L}$ & -- & 0.016 & 0.015 & -- & -- & $\begin{array}{c}3.2 \\
(\mathrm{mg} / \mathrm{kg})\end{array}$ & $\begin{array}{c}7.1 \\
(\mathrm{mg} / \mathrm{kg})\end{array}$ & 1.7 \\
\hline Manganese & $\mathrm{mg} / \mathrm{L}$ & 0.057 & 0.12 & 0.39 & 0.026 & 0.19 & $\begin{array}{c}127.0 \\
(\mathrm{mg} / \mathrm{kg})\end{array}$ & $\begin{array}{c}150.0 \\
(\mathrm{mg} / \mathrm{kg})\end{array}$ & 5.1 \\
\hline Mercury & $\mathrm{mg} / \mathrm{L}$ & 0.00097 & 0.0033 & 0.0029 & -- & 0.0014 & $\begin{array}{c}0.35 \\
(\mathrm{mg} / \mathrm{kg})\end{array}$ & $\begin{array}{c}0.28 \\
(\mathrm{mg} / \mathrm{kg})\end{array}$ & 0.037 \\
\hline Nickel & $\mathrm{mg} / \mathrm{L}$ & -- & -- & -- & -- & $\begin{array}{l}- \\
-\end{array}$ & -- & -- & 0.37 \\
\hline Silver & $\mathrm{mg} / \mathrm{L}$ & -- & -- & -- & -- & -- & -- & -- & 0.066 \\
\hline Zinc & $\mathrm{mg} / \mathrm{L}$ & 0.18 & 1.2 & 1.8 & 0.066 & 1.4 & $\begin{array}{c}166.0 \\
(\mathrm{mg} / \mathrm{kg})\end{array}$ & $\begin{array}{c}145.0 \\
(\mathrm{mg} / \mathrm{kg})\end{array}$ & 41.1 \\
\hline Total Metals & $\mathrm{mg} / \mathrm{L}$ & $<0.256$ & $<1.4$ & $<2.05$ & $<0.186$ & $<1.63$ & $\begin{array}{c}193.0 \\
(\mathrm{mg} / \mathrm{kg})\end{array}$ & $\begin{array}{l}<176.0 \\
(\mathrm{mg} / \mathrm{kg})\end{array}$ & $<48.1$ \\
\hline \multicolumn{10}{|c|}{ General Inorganics } \\
\hline $\begin{array}{c}\text { Nitrate plus } \\
\text { Nitrite }\end{array}$ & $\mathrm{mg} / \mathrm{L}$ & -- & -- & -- & 0.25 & -- & -- & -- & -- \\
\hline Phenolics & $\mathrm{mg} / \mathrm{L}$ & 0.012 & 0.041 & 0.27 & 0.027 & 0.29 & -- & -- & 0.29 \\
\hline Oil and Grease & $\mathrm{mg} / \mathrm{L}$ & 3.0 & 180 & 70.4 & $\begin{array}{c}5.7 \\
\text { (units } \\
\text { unknown) }\end{array}$ & 36.1 & $\begin{array}{l}9180.0 \\
(\mathrm{mg} / \mathrm{kg})\end{array}$ & $\begin{array}{l}7300.0 \\
(\mathrm{mg} / \mathrm{kg})\end{array}$ & 36.1 \\
\hline Cyanide & unknown & -- & -- & -- & 0.020 & -- & -- & -- & -- \\
\hline \multicolumn{10}{|c|}{ Radiological } \\
\hline Radium-226 & $\mathrm{pCi} / \mathrm{gm}$ & -- & -- & -- & -- & -- & -- & $\begin{array}{l}1.7 \pm 0.2 \\
(\mathrm{pCi} / \mathrm{gm})\end{array}$ & -- \\
\hline Uranium-234 & $\mathrm{pCi} / \mathrm{L}$ & -- & -- & $2.9 \pm 0.5^{5}$ & $11 \pm 3$ & $2.2 \pm 0.5^{5}$ & $\begin{array}{c}87 \pm 14 \\
(\mathrm{pCi} / g m)\end{array}$ & $\begin{array}{c}26 \pm 6 \\
(\mathrm{pCi} / \mathrm{gm})\end{array}$ & -- \\
\hline Uranium-235 & $\mathrm{pCi} / \mathrm{L}$ & -- & -- & -- & $1.1 \pm 1.0$ & -- & $\begin{array}{c}7.2 \pm 4 \\
(\mathrm{pCi} / \mathrm{gm})\end{array}$ & $\begin{array}{l}2.4 \pm 1.7 \\
(\mathrm{pCi} / \mathrm{gm})\end{array}$ & -- \\
\hline
\end{tabular}


Table D-1

Summary of Analytical Results for Detected Parameters, Tonopah Test Range, Septic Tank Sampling 1991 Sampling Event ${ }^{1}$

(Page 3 of 3)

\begin{tabular}{|c|c|c|c|c|c|c|c|c|c|}
\hline Parameter & Units & $33-1 A$ & 33-1B & $33-1 C$ & $33-2$ & $33-3$ & $33-8$ & 33-8 DUP & $33-10$ \\
\hline Uranium-238 & $\mathrm{pCi} / \mathrm{L}$ & -- & -- & $470 \pm 70$ & $1.6 \pm 1.3$ & -- & $\begin{array}{l}9.9 \pm 4.8 \\
(\mathrm{pCi} / \mathrm{gm})\end{array}$ & $\begin{array}{l}3.2 \pm 2.0 \\
(\mathrm{pCi} / \mathrm{gm})\end{array}$ & -- \\
\hline Potassium-40 & $\mathrm{pCi} / \mathrm{L}$ & $690 \pm 70^{5,6}$ & $590 \pm 70^{5,6}$ & $20 \pm 16$ & $720 \pm 80^{5,6}$ & $740 \pm 80^{5,6}$ & $\begin{array}{c}42 \pm 5^{6} \\
(p C i / g m)\end{array}$ & $\begin{array}{c}49 \pm 5 \\
(p C i / g m)\end{array}$ & $640 \pm 70^{5,6}$ \\
\hline Gross Alpha & $\mathrm{pCi} / \mathrm{L}$ & $3.8 \pm 2.7$ & -- & $96 \pm 20$ & -- & $21 \pm 10$ & $\begin{array}{c}11 \pm 5 \\
(\mathrm{pCi} / \mathrm{gm})\end{array}$ & $\begin{array}{c}11 \pm 5 \\
(\mathrm{pCi} / \mathrm{gm})\end{array}$ & $130 \pm 60$ \\
\hline Gross Beta & $\mathrm{pCi} / \mathrm{L}$ & $36 \pm 8$ & $38 \pm 10$ & $2 \pm 0.2$ & $63 \pm 10$ & $56 \pm 14$ & $\begin{array}{c}34 \pm 6 \\
(\mathrm{pCi} / \mathrm{gm})\end{array}$ & $\begin{array}{c}46 \pm 6 \\
(\mathrm{pCi} / \mathrm{gm})\end{array}$ & $190 \pm 80$ \\
\hline Tritium & $\mathrm{pCi} / \mathrm{mL}$ & -- & -- & -- & -- & -- & -- & -- & -- \\
\hline \multicolumn{10}{|c|}{ Polychlorinated Biphenyls } \\
\hline Aroclor 1242 & $\mu \mathrm{g} / \mathrm{L}$ & -- & 0.92 & -- & -- & -- & -- & -- & -- \\
\hline
\end{tabular}

Note: Values for samples considered liquid by the laboratory provided in volume units (i.e., $\mathrm{mg} / \mathrm{L}$ ). Values for samples considered solid by the laboratory provided in mass units (i.e., $\mathrm{mg} / \mathrm{kg}$ ).

${ }^{1}$ IT Corporation. 1994. Sandia National Laboratories/New Mexico, Septic Tank Monitoring Report, Tonopah Test Range and Nevada Test Site, June. Tonopah, NV. ${ }^{2}$ Method blank contained $11 \mu \mathrm{g} / \mathrm{kg}$ acetone

${ }^{3}$ Method blank contained $24 \mu \mathrm{g} / \mathrm{L}$ acetone

${ }^{4}$ Method blank contained $1.2 \mathrm{mg} / \mathrm{L}$ chromium

${ }^{5} 2$ sigma error

Method blank contained $480 \pm 70 \mathrm{pCi} / \mathrm{L}$ potassium -40

\section{--Not detected}

$\mathrm{pCi} / \mathrm{gm}=$ Picocuries per gram

$\mathrm{pCi} / \mathrm{mL}=$ Picocuries per milliliter

$\mu \mathrm{g} / \mathrm{L}=$ Micrograms per liter

$\mathrm{mg} / \mathrm{L}=$ Milligrams per liter

$\mu \mathrm{g} / \mathrm{kg}=$ Micrograms per kilogram

$\mathrm{pCi} / \mathrm{L}=$ Picocuries per liter 
Table D-2

Results of Septic Tank Sample Analysis, Tonopah Test Range, 1993 Sampling Event ${ }^{1}$

(Page 1 of 3 )

\begin{tabular}{|c|c|c|c|c|}
\hline Parameter & Units & $33-1$ & $33-3$ & $33-10$ \\
\hline \multicolumn{5}{|c|}{ Volatile Organics (EPA 624) (Aqueous Sample) } \\
\hline Methylene Chloride & $\mathrm{mg} / \mathrm{L}$ & 0.0054 & $\mathrm{~J}(0.0014)$ & $\mathrm{J}(0.0027)$ \\
\hline 1,4-Dichlorobenzene & $\mathrm{mg} / \mathrm{L}$ & 0.037 & 0.034 & 0.120 \\
\hline Ethylbenzene & $\mathrm{mg} / \mathrm{L}$ & -- & -- & 0.049 \\
\hline Toluene & $\mathrm{mg} / \mathrm{L}$ & 0.12 & $\mathrm{~J}(0.0032)$ & 0.280 \\
\hline \multicolumn{5}{|c|}{ Semivolatile Organics (EPA 625) (Aqueous Sample) } \\
\hline Naphthalene & $\mathrm{mg} / \mathrm{L}$ & 0.120 & $\mathrm{~J}(0.0086)$ & $\mathrm{J}(0.011)$ \\
\hline 1,4-Dichlorobenzene & $\mathrm{mg} / \mathrm{L}$ & 0.038 & 0.027 & 0.070 \\
\hline Dibenz(a,h)anthracene & $\mathrm{mg} / \mathrm{L}$ & $\mathrm{J}(0.0025)$ & -- & -- \\
\hline Bis(2-ethylhexyl)phthalate & $\mathrm{mg} / \mathrm{L}$ & $\mathrm{J}(0.0032)$ & 0.015 & - \\
\hline Benzo(g,h,i,)perylene & $\mathrm{mg} / \mathrm{L}$ & $\mathrm{J}(0.0039)$ & -- & - \\
\hline Indeno(1,2,3)-cd pyrene & $\mathrm{mg} / \mathrm{L}$ & $\mathrm{J}(0.0028)$ & - & -- \\
\hline \multicolumn{5}{|c|}{ Pesticides (EPA 608) (Aqueous Sample) } \\
\hline Endosulfan Sulfate & $\mathrm{mg} / \mathrm{L}$ & $\mathrm{J}(0.00026)$ & - & - \\
\hline \multicolumn{5}{|c|}{ PCBs (EPA 608) (Aqueous Sample) } \\
\hline PCBs & $\mathrm{mg} / \mathrm{L}$ & -- & - & -- \\
\hline \multicolumn{5}{|c|}{ Metals (Aqueous Sample) } \\
\hline Arsenic & $\mathrm{mg} / \mathrm{L}$ & 0.025 & 0.013 & 0.11 \\
\hline Barium & $\mathrm{mg} / \mathrm{L}$ & 0.12 & 0.094 & 0.79 \\
\hline Cadmium & $\mathrm{mg} / \mathrm{L}$ & $\mathrm{J}(0.0011)$ & $u(0.00050)$ & $J(0.0020)$ \\
\hline Chromium & $\mathrm{mg} / \mathrm{L}$ & $u(0.010)$ & $\mathrm{J}(0.0089)$ & 0.032 \\
\hline Copper & $\mathrm{mg} / \mathrm{L}$ & 0.036 & $\mathrm{~J}(0.014)$ & 0.18 \\
\hline Lead & $\mathrm{mg} / \mathrm{L}$ & $\mathrm{J}(0.0031)$ & $\mathrm{J}(0.0034)$ & $\mathrm{J}(0.0032)$ \\
\hline Manganese & $\mathrm{mg} / \mathrm{L}$ & 0.22 & 0.48 & 2.6 \\
\hline Mercury & $\mathrm{mg} / \mathrm{L}$ & $u(0.00020)$ & $\mathrm{u}(0.00020)$ & $u(0.00020)$ \\
\hline Nickel & $\mathrm{mg} / \mathrm{L}$ & $\mathrm{J}(0.025)$ & $\mathrm{J}(0.010)$ & 0.049 \\
\hline Selenium & $\mathrm{mg} / \mathrm{L}$ & $u(0.010)$ & $u(0.010)$ & $u(0.050)$ \\
\hline Silver & $\mathrm{mg} / \mathrm{L}$ & $\mathrm{J}(0.0063)$ & $\mathrm{J}(0.00044)$ & $\mathrm{J}(0.0075)$ \\
\hline Uranium & $\mathrm{mg} / \mathrm{L}$ & 0.00195 & 0.000321 & 0.00556 \\
\hline Zinc & $\mathrm{mg} / \mathrm{L}$ & 0.30 & 0.056 & 0.93 \\
\hline \multicolumn{5}{|c|}{ Miscellaneous Analytes (Aqueous Sample) } \\
\hline Phenolic Compounds & $\mathrm{mg} / \mathrm{L}$ & 0.010 & 0.030 & 0.051 \\
\hline Nitrates/Nitrites & $\mathrm{mg} / \mathrm{L}$ & $\mathrm{u}(1.0)$ & $\mathrm{u}(1.0)$ & $\mathrm{u}(1.0)$ \\
\hline Formaldehyde & $\mathrm{mg} / \mathrm{L}$ & $u(1.2)$ & $u(0.50)$ & 2.5 \\
\hline
\end{tabular}


Table D-2

Results of Septic Tank Sample Analysis, Tonopah Test Range, 1993 Sampling Event ${ }^{1}$

(Page 2 of 3 )

\begin{tabular}{|c|c|c|c|c|}
\hline Parameter & Units & $33-1$ & $33-3$ & $33-10$ \\
\hline Fluoride & $\mathrm{mg} / \mathrm{L}$ & 0.13 & 0.32 & 0.51 \\
\hline Cyanide & $\mathrm{mg} / \mathrm{L}$ & 0.038 & $u(0.010)$ & $u(0.010)$ \\
\hline Oil and Grease & $\mathrm{mg} / \mathrm{L}$ & 8.3 & 3.1 & 14.0 \\
\hline \multicolumn{5}{|c|}{ Radionuclides (Aqueous Sample) } \\
\hline Gross Alpha & $\mathrm{pCi} / \mathrm{L}$ & $5.18 \pm 3.95$ & $0.836 \pm 1.8$ & $11.2 \pm 5.28$ \\
\hline Gross Beta & $\mathrm{pCi} / \mathrm{L}$ & $49.2 \pm 6.72$ & $24.0 \pm 3.31$ & $75.9 \pm 9.48$ \\
\hline Tritium & $\mathrm{pCi} / \mathrm{L}$ & $-292 \pm 180$ & $-294 \pm 180$ & $-223 \pm 181$ \\
\hline Radium-226 & $\mathrm{pCi} / \mathrm{L}$ & $0.211 \pm 0.099$ & $0.149 \pm 0.072$ & $0.307 \pm 0.101$ \\
\hline Radium-228 & $\mathrm{pCi} / \mathrm{L}$ & $0.334 \pm 0.358$ & $0.402 \pm 0.246$ & $0.382 \pm 0.287$ \\
\hline \multicolumn{5}{|c|}{ Metals (Sludge Sample) } \\
\hline Arsenic & $\mathrm{mg} / \mathrm{kg}$ & 2.6 & 3.4 & 2.1 \\
\hline Barium & $\mathrm{mg} / \mathrm{kg}$ & 10.5 & 9.0 & 49.2 \\
\hline Cadmium & $\mathrm{mg} / \mathrm{kg}$ & $u(0.50)$ & $\mathrm{u}(0.50)$ & $u(0.50)$ \\
\hline Chromium & $\mathrm{mg} / \mathrm{kg}$ & $\mathrm{J}(0.86)$ & 1.2 & 6.3 \\
\hline Lead & $\mathrm{mg} / \mathrm{kg}$ & 1.6 & 10.7 & 2.4 \\
\hline Mercury & $\mathrm{mg} / \mathrm{kg}$ & 0.16 & $\mathrm{u}(0.10)$ & 0.13 \\
\hline Selenium & $\mathrm{mg} / \mathrm{kg}$ & $u(0.50)$ & $\mathrm{J}(0.41)$ & 0.32 \\
\hline Silver & $\mathrm{mg} / \mathrm{kg}$ & $\mathrm{J}(0.84)$ & 2.3 & 0.57 \\
\hline \multicolumn{5}{|c|}{ Radionuclides (Sludge Sample) } \\
\hline Gross Alpha & $\mathrm{pCi} / \mathrm{L}$ & $10.7 \pm 2.95$ & $19.9 \pm 4.77$ & $13.3 \pm 3.41$ \\
\hline Gross Beta & $\mathrm{pCi} / \mathrm{L}$ & $15.3 \pm 3.55$ & $35.6 \pm 7.41$ & $24.3 \pm 5.24$ \\
\hline Tritium (pCi/L) & $\mathrm{pCi} / \mathrm{L}$ & $-43 \pm 177$ & $-140 \pm 174$ & $-47.6 \pm 177$ \\
\hline Actinium-228 & $\mathrm{pCi} / \mathrm{L}$ & ND $(0.438)$ & $1.67 \pm 0.43$ & $1.31 \pm 0.36$ \\
\hline Americium-241 & $\mathrm{pCi} / \mathrm{L}$ & ND $(0.094)$ & ND (0.098) & ND (0.096) \\
\hline Bismuth-212 & $\mathrm{pCi} / \mathrm{L}$ & - & -- & $1.49 \pm 0.82$ \\
\hline Bismuth-214 & $\mathrm{pCi} / \mathrm{L}$ & $0.264 \pm 0.148$ & $1.27 \pm 0.28$ & $1.24 \pm 0.25$ \\
\hline Cadmium-109 & $\mathrm{pCi} / \mathrm{L}$ & -- & $2.90 \pm 0.984$ & $2.21 \pm 0.85$ \\
\hline Cerium-144 & $\mathrm{pCi} / \mathrm{L}$ & ND (0.277) & ND (0.29) & ND $(0.26)$ \\
\hline Cobalt-60 & $\mathrm{pCi} / \mathrm{L}$ & ND (0.084) & ND $(0.11)$ & ND $(0.11)$ \\
\hline Chromium-51 & $\mathrm{pCi} / \mathrm{L}$ & ND (1.18) & ND (1.48) & ND (1.38) \\
\hline Cesium-134 & $\mathrm{pCi} / \mathrm{L}$ & ND (0.078) & ND (0.084) & ND (0.077) \\
\hline Cesium-137 & $\mathrm{pCi} / \mathrm{L}$ & ND (0.103) & ND (0.12) & ND $(0.11)$ \\
\hline Europium-155 & $\mathrm{pCi} / \mathrm{L}$ & -- & -- & $0.067 \pm 0.10$ \\
\hline Iron-59 & $\mathrm{pCi} / \mathrm{L}$ & ND (0.290) & ND (0.33) & ND (0.34) \\
\hline
\end{tabular}


Table D-2

\section{Results of Septic Tank Sample Analysis, Tonopah Test Range,} 1993 Sampling Event ${ }^{1}$

(Page 3 of 3 )

\begin{tabular}{|c|c|c|c|c|}
\hline Parameter & Units & $33-1$ & $33-3$ & $33-10$ \\
\hline Lead-210 & $\mathrm{pCi} / \mathrm{L}$ & $1.10 \pm 0.915$ & $2.35 \pm 0.940$ & $3.57 \pm 1.13$ \\
\hline Lead-212 & $\mathrm{pCi} / \mathrm{L}$ & $0.464 \pm 0.121$ & $1.75 \pm 0.26$ & $1.53 \pm 0.22$ \\
\hline Lead-214 & $\mathrm{pCi} / \mathrm{L}$ & $0.513 \pm 0.149$ & $1.27 \pm 0.23$ & $1.10 \pm 0.22$ \\
\hline Potassium-40 & $\mathrm{pCi} / \mathrm{L}$ & $6.24 \pm 1.44$ & $24.5 \pm 3.60$ & $19.6 \pm 3.00$ \\
\hline Radium-224 & $\mathrm{pCi} / \mathrm{L}$ & $1.40 \pm 0.830$ & $3.02 \pm 1.08$ & $3.14 \pm 1.03$ \\
\hline Radium-226 & $\mathrm{pCi} / \mathrm{L}$ & $0.513 \pm 0.149$ & $1.27 \pm 0.23$ & $1.10 \pm 0.22$ \\
\hline Radium-228 & $\mathrm{pCi} / \mathrm{L}$ & ND $(0.440)$ & $1.67 \pm 0.43$ & $1.38 \pm 0.36$ \\
\hline Ruthenium-106 & $\mathrm{pCi} / \mathrm{L}$ & ND (0.799) & ND $(0.83)$ & ND $(0.80)$ \\
\hline Strontium-85 & $\mathrm{pCi} / \mathrm{L}$ & $0.115 \pm 0.083$ & -- & -- \\
\hline Thallium-208 & $\mathrm{pCi} / \mathrm{L}$ & $0.204 \pm 0.084$ & $0.661 \pm 0.14$ & $0.51 \pm 0.11$ \\
\hline Thorium-228 & $\mathrm{pCi} / \mathrm{L}$ & -- & $2.52 \pm 2.85$ & $3.05 \pm 2.62$ \\
\hline Thorium-231 & $\mathrm{pCi} / \mathrm{L}$ & ND (5.26) & ND (6.62) & ND (6.02) \\
\hline Thorium-234 & $\mathrm{pCi} / \mathrm{L}$ & $5.89 \pm 1.34$ & $3.36 \pm 1.26$ & $6.07 \pm 1.25$ \\
\hline Uranium-235 & $\mathrm{pCi} / \mathrm{L}$ & $0.332 \pm 0.080$ & $0.24 \pm 0.078$ & $0.37 \pm 0.084$ \\
\hline Uranium-238 & $\mathrm{pCi} / \mathrm{L}$ & $5.89 \pm 1.34$ & $3.36 \pm 1.26$ & $6.07 \pm 1.25$ \\
\hline Zirconium-95 & $\mathrm{pCi} / \mathrm{L}$ & ND (0.209) & ND (0.25) & ND $(0.26)$ \\
\hline
\end{tabular}

${ }^{1}$ IT Corporation. 1994. Sandia National Laboratories/New Mexico Septic Tank Monitoring Report, Tonopah Test Range and Nevada Test Site, June. Tonopah, NV.

$\mathrm{J}$ - Analyte present in sample below the quantitation limit listed in parentheses.

ND - Radionuclide not detected in sample at minimum detectable activity listed in parentheses.

$\mathrm{u}$ - Analyte not detected at laboratory detection limit listed in parentheses.

$\mathrm{mg} / \mathrm{L}$ - Milligrams per liter

$\mathrm{pCi} / \mathrm{L}$ - Picocuries per liter

$\mathrm{mg} / \mathrm{kg}$ - Milligrams per kilogram

-- None detected above laboratory reporting limits 
Table D-3

Summary of Sludge Sample Results for Detected Parameters

Tonopah Test Range

1999 Sampling Event

(Page 1 of 5 )

\begin{tabular}{|c|c|c|c|}
\hline Sample No. & Parameter & Results & Units \\
\hline \multicolumn{4}{|c|}{ Septic Tank 33-1A } \\
\hline TTR01185 & 1,4-Dichlorobenzene & 880,000 & $\mu \mathrm{g} / \mathrm{kg}$ \\
\hline TTR01185 & 2-Butanone & $180,000(B)^{c}$ & $\mu \mathrm{g} / \mathrm{kg}$ \\
\hline TTR01185 & Napthalene & $540,000(\mathrm{~J})^{\mathrm{a}}$ & $\mu \mathrm{g} / \mathrm{kg}$ \\
\hline TTR01185 & p-Isopropyltoluene & $470,000(B)^{c}$ & $\mu \mathrm{g} / \mathrm{kg}$ \\
\hline TTR01185 & 1,4-Dichlorobenzene & $1,200,000(J)^{d}$ & $\mu \mathrm{g} / \mathrm{kg}$ \\
\hline TTR01185 & Arsenic & 30.9 & $\mathrm{mg} / \mathrm{kg}$ \\
\hline TTR01185 & Barium & 771 & $\mathrm{mg} / \mathrm{kg}$ \\
\hline TTR01185 & Cadmium & 17.5 & $\mathrm{mg} / \mathrm{kg}$ \\
\hline TTR01185 & Chromium & 33.3 & $\mathrm{mg} / \mathrm{kg}$ \\
\hline TTR01185 & Lead & 46.4 & $\mathrm{mg} / \mathrm{kg}$ \\
\hline TTR01185 & Mercury & 4.2 & $\mathrm{mg} / \mathrm{kg}$ \\
\hline TTR01185 & Selenium & $4.4(\mathrm{~B})^{\mathrm{b}}$ & $\mathrm{mg} / \mathrm{kg}$ \\
\hline TTR01185 & Silver & $6.8(\mathrm{~B})^{\mathrm{b}}$ & $\mathrm{mg} / \mathrm{kg}$ \\
\hline TTR01185 & Diesel-Range Organics & $8,900(\mathrm{~J})^{\mathrm{e}}$ & $\mathrm{mg} / \mathrm{kg}$ \\
\hline TTR01185 & 1,4-Dichlorobenzene & 0.57 & $\mathrm{mg} / \mathrm{L}$ \\
\hline TTR01185 & Arsenic & $52.1(B)^{b}$ & $\mu \mathrm{g} / \mathrm{L}$ \\
\hline TTR01185 & Barium & 2,110 & $\mu \mathrm{g} / \mathrm{L}$ \\
\hline TTR01185 & Chromium & $9.2(\mathrm{~B})^{\mathrm{b}}$ & $\mu \mathrm{g} / \mathrm{L}$ \\
\hline TTR01185 & $\mathrm{K}-40$ & $10.4 \pm 3.7(\mathrm{~J})$ & $\mathrm{pCi} / \mathrm{g}$ \\
\hline TTR01185 & $\mathrm{Pb}-212$ & $0.65 \pm 0.32(\mathrm{~J})$ & $\mathrm{pCi} / \mathrm{g}$ \\
\hline \multicolumn{4}{|c|}{ Septic Tank 33-1B } \\
\hline TTR01187 & 1,4-Dichlorobenzene & 110,000 & $\mu \mathrm{g} / \mathrm{kg}$ \\
\hline TTR01187 & p-Isopropyltoluene & $560,000(B)^{c}$ & $\mu \mathrm{g} / \mathrm{kg}$ \\
\hline TTR01187 & Arsenic & 44.6 & $\mathrm{mg} / \mathrm{kg}$ \\
\hline TTR01187 & Barium & 426 & $\mathrm{mg} / \mathrm{kg}$ \\
\hline TTR01187 & Cadmium & 15.2 & $\mathrm{mg} / \mathrm{kg}$ \\
\hline TTR01187 & Chromium & 21.5 & $\mathrm{mg} / \mathrm{kg}$ \\
\hline
\end{tabular}


Table D-3

Summary of Sludge Sample Results for Detected Parameters Tonopah Test Range

1999 Sampling Event

(Page 2 of 5 )

\begin{tabular}{|c|c|c|c|}
\hline Sample No. & Parameter & Results & Units \\
\hline \multicolumn{4}{|c|}{ Septic Tank 33-1B } \\
\hline TTR01187 & Lead & 52.2 & $\mathrm{mg} / \mathrm{kg}$ \\
\hline TTR01187 & Mercury & 1.6 & $\mathrm{mg} / \mathrm{kg}$ \\
\hline TTR01187 & Selenium & $2.2(\mathrm{~B})^{\mathrm{b}}$ & $\mathrm{mg} / \mathrm{kg}$ \\
\hline TTR01187 & Silver & 6.6 & $\mathrm{mg} / \mathrm{kg}$ \\
\hline TTR01187 & Diesel-Range Organics & $3,400(J)^{e}$ & $\mathrm{mg} / \mathrm{kg}$ \\
\hline TTR01187 & Arsenic & $75.8(\mathrm{~B})^{\mathrm{b}}$ & $\mu \mathrm{g} / \mathrm{L}$ \\
\hline TTR01187 & Barium & $922(\mathrm{~B})^{\mathrm{b}}$ & $\mu \mathrm{g} / \mathrm{L}$ \\
\hline TTR01187 & Chromium & $6.3(\mathrm{~B})^{\mathrm{b}}$ & $\mu \mathrm{g} / \mathrm{L}$ \\
\hline TTR01187 & Silver & $6(\mathrm{~B})^{\mathrm{b}}$ & $\mu \mathrm{g} / \mathrm{L}$ \\
\hline TTR01187 & Th-234 & $6.3 \pm 2.8(\mathrm{~J})$ & $\mathrm{pCi} / \mathrm{g}$ \\
\hline TTR01187 & U-234 & $11.4 \pm 1.4$ & $\mathrm{pCi} / \mathrm{g}$ \\
\hline TTR01187 & U-235 & $0.40 \pm 0.10(\mathrm{LT})$ & $\mathrm{pCi} / \mathrm{g}$ \\
\hline TTR01187 & U-238 & $6.56 \pm 0.85$ & $\mathrm{pCi} / \mathrm{g}$ \\
\hline \multicolumn{4}{|c|}{ Septic Tank 33-3 } \\
\hline TTR01197 & $1,2,4$-Trimethylbenzene & $3,300(J)^{i}$ & $\mu \mathrm{g} / \mathrm{kg}$ \\
\hline TTR01197 & 1,3,5-Trimethylbenzene & $2,000(J)^{i}$ & $\mu \mathrm{g} / \mathrm{kg}$ \\
\hline TTR01197 & 1,4-Dichlorobenzene & 9,000 & $\mu \mathrm{g} / \mathrm{kg}$ \\
\hline TTR01197 & Acetone & $1,800(J)^{a, h}$ & $\mu \mathrm{g} / \mathrm{kg}$ \\
\hline TTR01197 & Isopropylbenzene & $590(J)^{i}$ & $\mu \mathrm{g} / \mathrm{kg}$ \\
\hline TTR01197 & $\mathrm{m}+\mathrm{p}$-Xylene & $1,000(J)^{i}$ & $\mu \mathrm{g} / \mathrm{kg}$ \\
\hline TTR01197 & Napthalene & 1,400 & $\mu \mathrm{g} / \mathrm{kg}$ \\
\hline TTR01197 & o-Xylene & $490(\mathrm{~J})^{\mathrm{i}}$ & $\mu \mathrm{g} / \mathrm{kg}$ \\
\hline TTR01197 & p-Isopropyltoluene & $800(J)^{i}$ & $\mu \mathrm{g} / \mathrm{kg}$ \\
\hline TTR01197 & Tert-Butylbenzene & $370(\mathrm{~J})^{i}$ & $\mu \mathrm{g} / \mathrm{kg}$ \\
\hline TTR01197 & Toluene & 1,500 & $\mu \mathrm{g} / \mathrm{kg}$ \\
\hline TTR01197 & Arsenic & 72.2 & $\mathrm{mg} / \mathrm{kg}$ \\
\hline TTR01197 & Barium & 152 & $\mathrm{mg} / \mathrm{kg}$ \\
\hline
\end{tabular}


Table D-3

Summary of Sludge Sample Results for Detected Parameters Tonopah Test Range

1999 Sampling Event

(Page 3 of 5)

\begin{tabular}{|c|c|c|c|}
\hline Sample No. & Parameter & Results & Units \\
\hline \multicolumn{4}{|c|}{ Septic Tank 33-3 } \\
\hline TTR01197 & Cadmium & 14.3 & $\mathrm{mg} / \mathrm{kg}$ \\
\hline TTR01197 & Chromium & 46 & $\mathrm{mg} / \mathrm{kg}$ \\
\hline TTR01197 & Lead & 213 & $\mathrm{mg} / \mathrm{kg}$ \\
\hline TTR01197 & Mercury & $4.1(J)^{g}$ & $\mathrm{mg} / \mathrm{kg}$ \\
\hline TTR01197 & Diesel-Range Organics & $1,800(J)^{e}$ & $\mathrm{mg} / \mathrm{kg}$ \\
\hline TTR01197 & Arsenic & 114 & $\mu \mathrm{g} / \mathrm{L}$ \\
\hline TTR01197 & Barium & 1,940 & $\mu \mathrm{g} / \mathrm{L}$ \\
\hline TTR01197 & Mercury & $0.23(\mathrm{~B})^{\mathrm{b}}$ & $\mu \mathrm{g} / \mathrm{L}$ \\
\hline TTR01197 & $\mathrm{K}-40$ & $8.3 \pm 3.9(\mathrm{~J})$ & $\mathrm{pCi} / \mathrm{g}$ \\
\hline TTR01197 & Th-234 & $11.7 \pm 3.5(\mathrm{~J})$ & $\mathrm{pCi} / \mathrm{g}$ \\
\hline TTR01197 & U-234 & $28.9 \pm 3.5$ & $\mathrm{pCi} / \mathrm{g}$ \\
\hline TTR01197 & U-235 & $0.93 \pm 0.18$ & $\mathrm{pCi} / \mathrm{g}$ \\
\hline TTR01197 & U-238 & $15.6 \pm 1.9$ & $\mathrm{pCi} / \mathrm{g}$ \\
\hline \multicolumn{4}{|c|}{ Septic Tank 33-3 Duplicate } \\
\hline TTR01205 & 1,2-Dichlorobenzene & 59 & $\mu \mathrm{g} / \mathrm{kg}$ \\
\hline TTR01205 & 1,2,4-Trimethylbenzene & 520 & $\mu \mathrm{g} / \mathrm{kg}$ \\
\hline TTR01205 & 1,3,5-Trimethylbenzene & 230 & $\mu \mathrm{g} / \mathrm{kg}$ \\
\hline TTR01205 & 1,4-Dichlorobenzene & 1,300 & $\mu \mathrm{g} / \mathrm{kg}$ \\
\hline TTR01205 & 2-Chlorotoluene & 79 & $\mu \mathrm{g} / \mathrm{kg}$ \\
\hline TTR01205 & Acetone & $190(\mathrm{~B})^{\mathrm{c}}$ & $\mu \mathrm{g} / \mathrm{kg}$ \\
\hline TTR01205 & Ethylbenzene & 59 & $\mu \mathrm{g} / \mathrm{kg}$ \\
\hline TTR01205 & Isopropylbenzene & 67 & $\mu \mathrm{g} / \mathrm{kg}$ \\
\hline TTR01205 & $\mathrm{m}+\mathrm{p}$-Xylene & 260 & $\mu \mathrm{g} / \mathrm{kg}$ \\
\hline TTR01205 & n-Butylbenzene & 61 & $\mu \mathrm{g} / \mathrm{kg}$ \\
\hline TTR01205 & n-Propylbenzene & 120 & $\mu \mathrm{g} / \mathrm{kg}$ \\
\hline TTR01205 & o-Xylene & 130 & $\mu \mathrm{g} / \mathrm{kg}$ \\
\hline TTR01205 & p-Isopropyltoluene & 180 & $\mu \mathrm{g} / \mathrm{kg}$ \\
\hline TTR01205 & Toluene & 150 & $\mu \mathrm{g} / \mathrm{kg}$ \\
\hline
\end{tabular}


Table D-3

Summary of Sludge Sample Results for Detected Parameters Tonopah Test Range

1999 Sampling Event

(Page 4 of 5)

\begin{tabular}{|c|c|c|c|}
\hline Sample No. & Parameter & Results & Units \\
\hline \multicolumn{4}{|c|}{ Septic Tank 33-3 Duplicate } \\
\hline TTR01205 & Bis(2-Ethylhexyl)Phthalate & 68,000 & $\mu \mathrm{g} / \mathrm{kg}$ \\
\hline TTR01205 & Arsenic & 62.5 & $\mathrm{mg} / \mathrm{kg}$ \\
\hline TTR01205 & Barium & $218(J)^{g}$ & $\mathrm{mg} / \mathrm{kg}$ \\
\hline TTR01205 & Cadmium & 34.3 & $\mathrm{mg} / \mathrm{kg}$ \\
\hline TTR01205 & Chromium & 211 & $\mathrm{mg} / \mathrm{kg}$ \\
\hline TTR01205 & Lead & $1,490(J)^{j}$ & $\mathrm{mg} / \mathrm{kg}$ \\
\hline TTR01205 & Mercury & $3.5(J)^{g}$ & $\mathrm{mg} / \mathrm{kg}$ \\
\hline TTR01205 & Silver & $6.3(\mathrm{~B})^{\mathrm{b}}$ & $\mathrm{mg} / \mathrm{kg}$ \\
\hline TTR01205 & Diesel-Range Organics & 49,000 & $\mathrm{mg} / \mathrm{kg}$ \\
\hline TTR01205 & K-40 & $12.3 \pm 5.1(\mathrm{~J})$ & $\mathrm{pCi} / \mathrm{g}$ \\
\hline TTR01205 & Th-234 & $10.5 \pm 3.3(\mathrm{~J})$ & $\mathrm{pCi} / \mathrm{g}$ \\
\hline TTR01205 & U-234 & $2.26 \pm 0.34$ & $\mathrm{pCi} / \mathrm{g}$ \\
\hline TTR01205 & U-235 & $0.099 \pm 0.048(B)$ & $\mathrm{pCi} / \mathrm{g}$ \\
\hline TTR01205 & U-238 & $1.79 \pm 0.28$ & $\mathrm{pCi} / \mathrm{g}$ \\
\hline \multicolumn{4}{|c|}{ Septic Tank 33-10 } \\
\hline TTR01200 & Acetone & $82(J)^{k}$ & $\mu \mathrm{g} / \mathrm{kg}$ \\
\hline TTR01200 & Arsenic & 14.2 & $\mathrm{mg} / \mathrm{kg}$ \\
\hline TTR01200 & Barium & 93.1 & $\mathrm{mg} / \mathrm{kg}$ \\
\hline TTR01200 & Cadmium & $3.6(\mathrm{~J})^{\prime}$ & $\mathrm{mg} / \mathrm{kg}$ \\
\hline TTR01200 & Chromium & 19.9 & $\mathrm{mg} / \mathrm{kg}$ \\
\hline TTR01200 & Lead & $101(J)^{g, j}$ & $\mathrm{mg} / \mathrm{kg}$ \\
\hline TTR01200 & Mercury & 3.8 & $\mathrm{mg} / \mathrm{kg}$ \\
\hline TTR01200 & Selenium & 9.5 & $\mathrm{mg} / \mathrm{kg}$ \\
\hline TTR01200 & Silver & 3.9 & $\mathrm{mg} / \mathrm{kg}$ \\
\hline TTR01200 & Diesel-Range Organics & 1,300 & $\mathrm{mg} / \mathrm{kg}$ \\
\hline TTR01200 & Arsenic & 167 & $\mu \mathrm{g} / \mathrm{L}$ \\
\hline TTR01200 & Barium & 2,200 & $\mu \mathrm{g} / \mathrm{L}$ \\
\hline TTR01200 & $\mathrm{K}-40$ & $18.1 \pm 6.2(\mathrm{~J})$ & $\mathrm{pCi} / \mathrm{g}$ \\
\hline
\end{tabular}


Table D-3

Summary of Sludge Sample Results for Detected Parameters Tonopah Test Range 1999 Sampling Event

(Page 5 of 5 )

\begin{tabular}{||c|c|c|c|}
\hline Sample No. & Parameter & Results & Units \\
\hline \hline \multicolumn{3}{|c|}{ Septic Tank 33-10 } & \\
\hline \hline TTR01200 & Pb-212 & $0.88 \pm 0.46(\mathrm{~J})$ & $\mathrm{pCi} / \mathrm{g}$ \\
\hline TTR01200 & $\mathrm{U}-234$ & $13.5 \pm 1.7$ & $\mathrm{pCi} / \mathrm{g}$ \\
\hline TTR01200 & $\mathrm{U}-235$ & $0.371 \pm 0.096(\mathrm{LT})$ & $\mathrm{pCi} / \mathrm{g}$ \\
\hline TTR01200 & $\mathrm{U}-238$ & $7.36 \pm 0.94$ & $\mathrm{pCi} / \mathrm{g}$ \\
\hline
\end{tabular}

Shaded data is Toxicity Characteristic Leaching Procedure result.

${ }^{a}$ Associated continuing calibration showed elevated \%D for compound.

${ }^{\mathrm{b}}$ Reported value was obtained from a reading that was less than the Contract-Required Detection Limit (CRDL), but greater than or equal to the Instrument Detection Limit (IDL) for the inorganic analyses.

${ }^{c}$ Analyte is detected in the associated method blank as well as the sample for organic analyses.

d Surrogates diluted out.

${ }^{\text {e }}$ Surrogate recovery exceeded the lower limit.

${ }^{\mathrm{f}}$ Internal standard area count exceeded the QC limits.

${ }^{9}$ Duplicate precision analyses were outside control limits.

${ }^{\mathrm{h}}$ Average relative response factor $<0.05$.

'Mass spectra do not match reference spectra.

i Spike recovery was outside control limits.

${ }^{k}$ Surrogate recovery exceeded the upper limits.

'ICP serial dilution recovery was not met.

$\mathrm{J}$ - Estimated value

B - Analyte concentration greater than Minimum Detectable Concentration

LT - Concentration is greater than the Minimum Detectable Concentration, but less than the reporting level

$\mu \mathrm{g} / \mathrm{kg}$ - Microgram(s) per kilogram $\mathrm{pCi} / \mathrm{kg}$ - Picocurie(s) per kilogram $\mathrm{mg} / \mathrm{kg}$ - Milligram(s) per kilogram

$\mathrm{mg} / \mathrm{L}$ - Milligram(s) per liter

$\mu \mathrm{g} / \mathrm{L}$ - Microgram(s) per liter 


\section{Appendix E}

\section{Response to NDEP Comments}




\section{NEVADA ENVIRONMENTAL RESTORATION PROJECT}

DOCUMENT REVIEW SHEET

\begin{tabular}{|c|c|c|c|c|c|}
\hline \multicolumn{4}{|c|}{$\begin{array}{l}\text { 1. Document Title/Number: } \text { Draft Corrective Action Investigation Plan for Corrective Action Unit 409: Other } \\
\text { Waste Sites, Tonopah Test Range, Nevada }\end{array}$} & \multicolumn{2}{|l|}{ 2. Document Date: July 2000} \\
\hline \multicolumn{4}{|l|}{ 3. Revision Number: } & \multicolumn{2}{|c|}{ 4. Originator/Organization: IT Corporation } \\
\hline \multicolumn{4}{|c|}{ 5. Responsible DOE/NV ERP Project Mgr.: Janet Appenzeller-Wing } & \multicolumn{2}{|c|}{ 6. Date Comments Due: August 18, 2000} \\
\hline \multicolumn{6}{|c|}{ 7. Review Criteria: Full } \\
\hline \multicolumn{4}{|c|}{ 8. Reviewer/Organization/Phone No.: Gregory A. Raab, NDEP, 486-2867 } & \multicolumn{2}{|l|}{ 9. Reviewer's Signature: } \\
\hline $\begin{array}{l}\text { 10. Comment } \\
\text { Number/ } \\
\text { Location }\end{array}$ & 11. Type* & 12. Comment & & 13. Comment Response & $\begin{array}{c}14 . \\
\text { Accept }\end{array}$ \\
\hline $\begin{array}{l}\text { 1) } 2^{\text {nd }} \text { Paragraph } \\
\text { 3rd Sentence } \\
\text { Page A-3 of A-28 }\end{array}$ & & $\begin{array}{l}\text { "...Those basic expectations and roles are...". What follows, except } \\
\text { for the last bullet, is not a listing of basic expectations or roles. As } \\
\text { this apparently is part of a "boiler-plate" document, it may have been } \\
\text { compromised in replication, and not properly edited. Since the use } \\
\text { of boiler plates assumes across the board acceptance, this should } \\
\text { be reviewed at the next FFACO meeting for discussion. It needs to } \\
\text { be rewritten to reflect that the types of data must fall within the data } \\
\text { quality objective requirements. The DQOs are set to meet the } \\
\text { expectations to close under NDEP requirements. }\end{array}$ & $\begin{array}{l}\text { NDEP con } \\
\text { "clear exp } \\
\text { representa } \\
\text { bullets anc } \\
\text { inappropri } \\
\text { To addres } \\
\text { in the secc } \\
\text { follows: "7 } \\
\text { considere }\end{array}$ & $\begin{array}{l}\text { nt interpreted to mean that the phrase } \\
\text { tions and roles of responsibility" is not } \\
\text { of the bullets that follow, rather than the } \\
\text { companying text are inaccurate or } \\
\text { comment, second and third sentences } \\
\text { oaragraph on page A-3 were rewritten as } \\
\text { tain this goal, the following topics are }\end{array}$ & Yes \\
\hline $\begin{array}{l}\text { 2) } 3^{\text {rd }} \text { Paragraph } \\
1^{\text {st }} \text { Sentence } \\
\text { Page A-5 of A-28 }\end{array}$ & & $\begin{array}{l}\text { "...The quantity of data should be statistically valid to ensure the } \\
\text { CASs are properly characterized...". Clarify how is this done, } \\
\text { especially in the light of the statement on page A-25, first } \\
\text { paragraph, last sentence: "...since biased sampling will be } \\
\text { conducted instead of random sampling, confidence levels cannot be } \\
\text { calculated for the sampling of the disposal pits..." }\end{array}$ & $\begin{array}{l}\text { Third para } \\
\text { The sente } \\
\text { sampling } \\
\text { (as oppos } \\
\text { approach) }\end{array}$ & $\begin{array}{l}\text { h, first sentence, page A-5 deleted. } \\
\text { is not appropriate to the topic. A biased } \\
\text { oach in the primary investigation plan } \\
\text { a statistically-generated random } \\
\text { xplained and justified in Section A.6.1. }\end{array}$ & Yes \\
\hline $\begin{array}{c}\text { 3) Table A.2-3 } \\
\text { Page A-12 of A-28 }\end{array}$ & & $\begin{array}{l}\text { Conceptual Site Model: Although there is no requirement for a } \\
\text { diagram or cross section of the model, one would make it easier to } \\
\text { visualize and understand. }\end{array}$ & $\begin{array}{l}\text { A diagram } \\
\text { drawn and } \\
\text { Section } A \text {. } \\
\text { diagramm }\end{array}$ & $\begin{array}{l}\text { c sketch of the disposal pits has been } \\
\text { erted. The following sentence added to } \\
\text { page A-9: "Figure A.2-1 provides a } \\
\text { sketch of the disposal pits." }\end{array}$ & Yes \\
\hline
\end{tabular}

a Comment Types: $\mathrm{M}=$ Mandatory, $\mathrm{S}=$ Suggested.

Return Document Review Sheets to DOE/NV Environmental Restoration Division, Attn: QAC, M/S 505. 


\section{Distribution}

*Provide copy in distribution of Revision 0 and subsequent revisions if applicable. Copies of only the NDEP-approved document will be distributed to others.

Paul J. Liebendorfer

State of Nevada

Bureau of Federal Facilities

Division of Environmental Protection

333 W. Nye Lane, Room 138

Carson City, NV 89706-0851

Michael McKinnon

State of Nevada

Bureau of Federal Facilities

Division of Environmental Protection

555 E. Washington, Suite 4300

Las Vegas, NV 89101

Sabrina Lawrence

Environmental Restoration Division

DOE/Nevada Operations Office

P.O. Box 98518, M/S 505

Las Vegas, NV 89193-8518

Janet Appenzeller-Wing

Environmental Restoration Division

DOE/Nevada Operations Office

P.O. Box 98518, M/S 505

Las Vegas, NV 89193-8518

Kevin Cabble

Environmental Restoration Division

DOE/Nevada Operations Office

P.O. Box 98518, M/S 505

Las Vegas, NV 89193-8518
2 (Controlled)*

1 (Controlled)*

1 (Controlled)*

1 (Uncontrolled)*

1 (Uncontrolled)* 
Gerald Carpenter

U.S. Air Force DOE Liaison Office

DOE/Nevada Operations Office

P.O. Box 98518, M/S 505

Las Vegas, NV 89193-8518

Wayne Johnson

Bechtel Nevada

P.O. Box 98521, M/S NTS306

Las Vegas, NV 89193-8521

Alison Urbon

Bechtel Nevada

P.O. Box 98521, M/S NTS306

Las Vegas, NV 89193-8521

John Davis

ITLV

P.O. Box 93838

Las Vegas, NV 89193

Trenton Richards

ITLV

P.O. Box 93838

Las Vegas, NV 89193

Jeffrey Johnson

ITLV

P.O. Box 93838

Las Vegas, NV 89193

IT Corporation Central Files

P.O. Box 93838

Las Vegas, NV 89193

Manager Southern Nevada FFACO

Public Reading Room

P.O. Box 98521, M/S NLV040

Las Vegas, NV 89193-8521
1 (Uncontrolled)*

1 (Uncontrolled)*

1 (Uncontrolled)*

1 (Uncontrolled)*

1 (Uncontrolled)*

1 (Uncontrolled)*

1 (Uncontrolled)*

1 (Controlled)

1 (Uncontrolled) 
Manager, Northern Nevada FFACO

Public Reading Room

Nevada State Library and Archives Federal Publications

100 North Stewart Street

Carson City, NV 89701-4285

FFACO Support Offices

IT Corporation

P.O. Box 93838

Las Vegas, NV 89193

Technical Information Resource Center

DOE/Nevada Operations Office

P.O. Box 98518, M/S 505

Las Vegas, NV 89193-8518

U.S. Department of Energy

Office of Scientific and Technical Information

P.O. Box 62

Oak Ridge, TN 37831
1 (Controlled)

1 (Uncontrolled)

1 (Uncontrolled)

1 (Uncontrolled)

1 (Uncontrolled, electronic copy) 